\title{
EFEITO DE DIFERENTES REGIMES DE FORNECIMENTO DE COLOSTRO POR PERIODO PROLONGADO SOBRE O COMPORTAMENTO IMUNOLÓGICO E DESEMPENHO DE BEZERROS LEITEIROS
}

\author{
CLAUDIA DANIELE \\ Engentieira Agrónoma
}

Orientador: Prof. Dr. RAUL MACHADO NETO

\begin{abstract}
Dissertação apresentada à Escola Superior de Agricultura "Luiz de Queiroz", da Universidade de Săo Paulo, para obtenção do título de Mestre em Agronomia - Area de Concentração: Ciência Animal e Pastagens.
\end{abstract}

PIRACICABA

Estado de São Paulo - Brasil

Fevereiro - 1993 
Ficha catalografica preparada pela Seçăo de Livros da Divisăo de Fiblioteca e Documentaçăo - FCLQ/uSF

Daniele, Claudia

Disse Efeito de diferentes regimes de fornecimento de colostro por periodo prolongado sobre a comportamento imunalogico e desempentio de bezerros leiteiros.

Firacicaba, 1993.

$141 \mathrm{p}$.

Diss. (Mestre) - ESALQ

Eibliografia.

i. Eezerro leiteiro - Comportamento imunológico

2. Eezerro leiteiro - Desempentio 3. Colostro-Dieta

I. Escola Superior de fgricultura Luiz de Rueiroz.

Firacicaba

CDD 636.214 
EFEITO DE DIFERENTES REGIMES DE FORNECIMENTO

DE COLOSTRO POR PERIODO PROLONGADO SOBRE O COMPORTAMENTO IMUNOL GGICO E DESEMPENHO DE BEZERROS LEITEIROS

Cláudia Daniele

Aprovada em: $05 / 04 / 93$

Comissão Julgadora:
Prof. Dr. Raul Machado Neto
ESALQ/USP
Prot. Dr. Raul Dantas D'Arce
ESALQRUSP
Prof. Dr. Ciniro Costa
UNESP/Botucatu

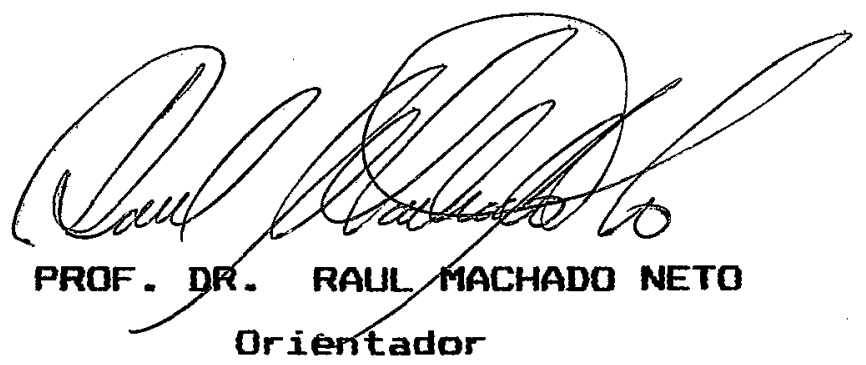


$\bar{A}$

minha querida חลี CONCE IÇÃO

por tuda.

DEDICO. 


\section{AGRADECIMENTOS}

Ao Prof. Dr. Raul Machado Neto, orientador único, que com paciencia, dedicaçăo e amizade me orientou na execução deste trabalho, ajudando de forma exemplar a enriquecer meus conhecimentos;

Ao Prof. Dr. Raul Dantas d'Arce, pela valibsa colaboraçăo e apoio recebidos;

Ao Prof. Dr. Irineu Umberto Packer, pela dedicada ajuda na realização das análises estatisticas;

Ã Familia Jank, especialmente Marcos Sawaya Jank e Roberto Hugo Jank Jr., pelo consentimento e amplas facilidades colocados à disposiçăo, permitindo que este trabal ho se concretizasse na Fazenda Agrindus S.A.;

Aos funcionarios de campo, de escritorio e de todos os setores da Fazenda Agrindus S.A., pela eficiente colaboração prestada e agradável amizade partilhada;

Aos funcionários do Depto. de Zoologia da Escola Superior de Agricultura "Luiz de Queiroz";

Ás amigas e companheiras que tanto contribui ram para a realizaçă das análises laboratoriais deste trabalho, especialmente Rosana Bessi;

Aos profissionais do CIAGRI-ESALQ, pela valiosa ajuda nas análises estatrsticas; 
Aos colegas, companheiros, amigos de curso e especialmente pessoas queridas que sempre estiveram presentes durante este trabalio prestando apoio e dedicação imprescindi veis;

E, finalmente, a todos aqueles que direta ou indiretamente deram sua colaboração, permitindo a realizaçăo deste trabal ho. 
SUMARIO

Página

LISTA DE FIGURAS $\ldots \ldots \ldots \ldots \ldots \ldots \ldots \ldots \ldots \ldots \ldots \ldots \ldots$

viii

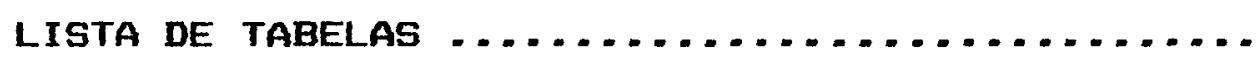
ix

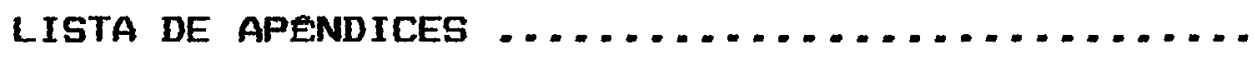
$x i$

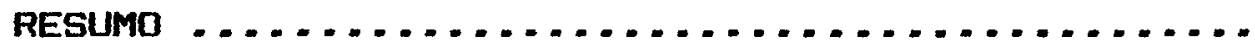

xisi

SUMMARY

xyii

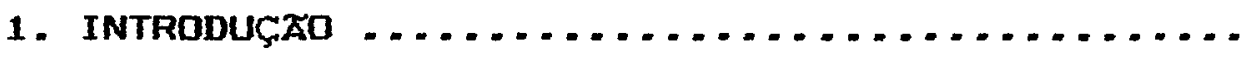

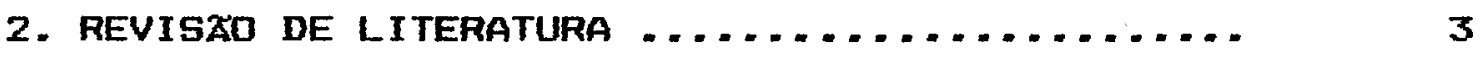

2.1. Imunidade passiva ................... 3

2.2. Importáncia do colostro ................ 4

2.3. Imunoglobulinas .......................

2.4. Colostro e sua produção ................ 10

2.5. Transferência de imunidade passiva em be-

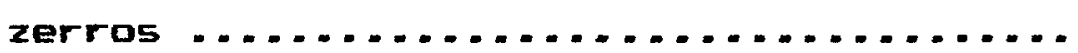

2.5.1. Niveis de imungglobulinas absorvi-

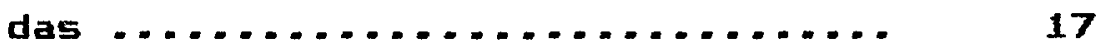

2.5.2. Fatores que afetam o processo de

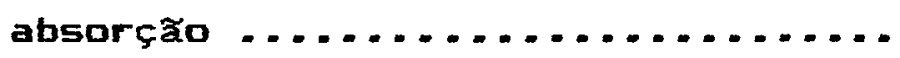

2.6. Transição da imunidade exógena para imuni-

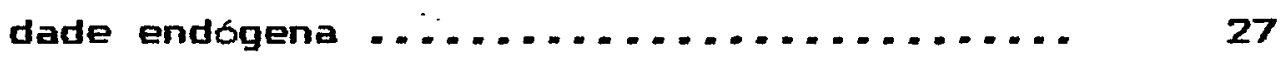

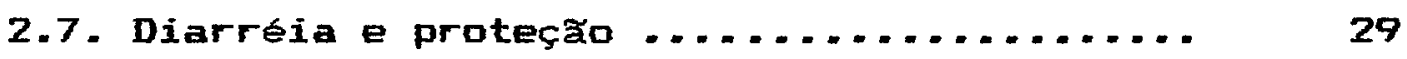

2.7.1. Consideraçß̈es gerais ............. 29

2.7.2. Açáa dos patógenos causadores de diarreia ................................ 32

2.7.3. Imunidade passiva sistémica $\times$ pro-

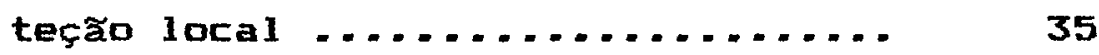

2.7.4. Colostro suplementar ............ 39 
Pagina

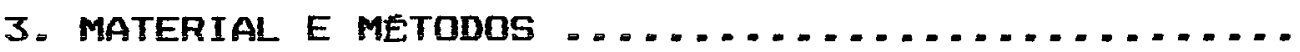

3.1. Local ...............................

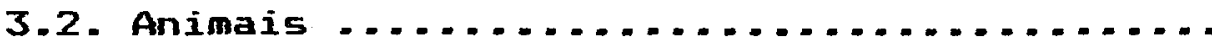

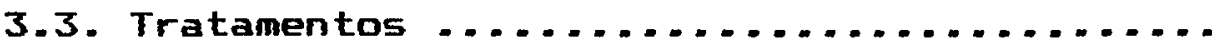

3.4. Colostro ................................ 49

3.5. Amostragen de sangue .................... 55

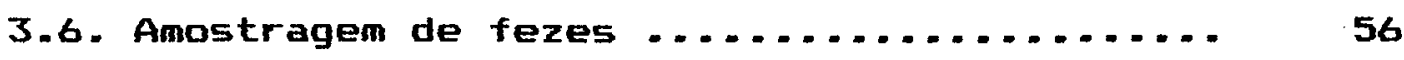

3.7. Comportamento e desempenho ............. 58

3.8. Análise das amostras ................... 5

3.9. Delineamento experimental e análise estatistica ..............................

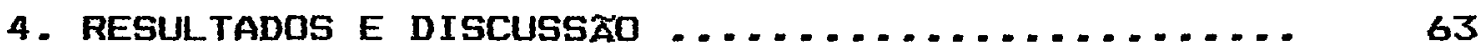

4.1. Proteina total (PT) serica ............. 63

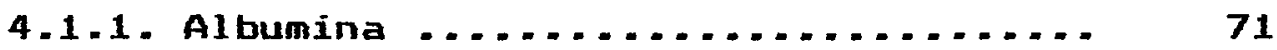

4.2. Imungglobulina serica (Ig G) ............. 76

4.3. Parâmetros sericos e desempento ........... 87 4.3.1. Peso ............................ 87

4.3.2. Diarreia ....................... 98

4.4. Consideraçžs gerais ................... 110

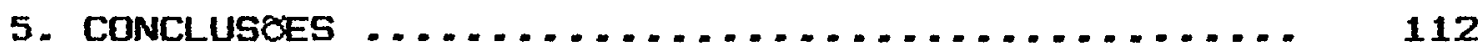

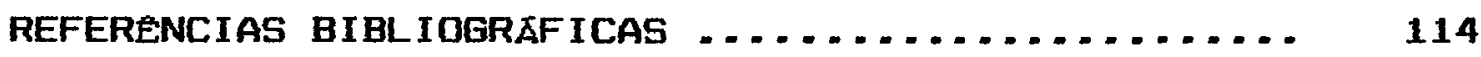

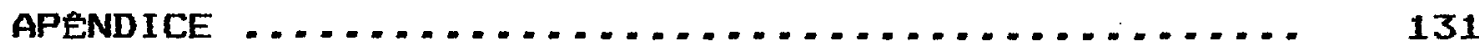




\section{LISTA DE FIGURAS}

FIGURA

Pagina

1 Quantidades medias de Ig (gramas) fornecidas por dia aos animais que receberam colostro por períado prolongado .......

2 Concentração média de proteina total serica $(g / d 1)$ nos tratamentos ..........

3 Concentração media de albumina sórica

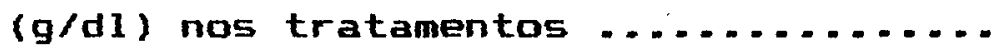

4 Concentração média de Ig G serica (mg/ m1) nos tratamentos .................

5 Pesos medios observados nos tratamentos durante 60 dias de idade .............

6 Notas medias diárias de cor de fezes nos

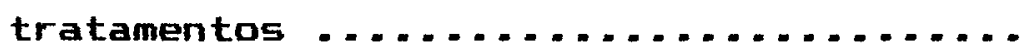

7 Notas médias díarias de consistoncia de fezes nos tratamentos ................

Dias em que os animais apresentaram diarréia (parametro: cor de fezes) .....

9 Dias em que os animais apresentaram diarréia parâmetro: consistência de fe-

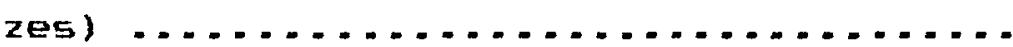




\section{LISTA DE TABELAS}

TABELA

Pagina

1 Composição do colostro e do leite de

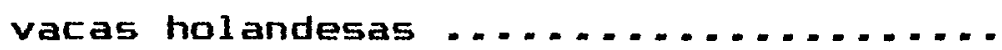

2 Concentração de Ig $G(m g / m 1)$ no colostro de primeira ordenha de vacas leiteiras da raça holandesa .............

3 Concentração de Ig M (mg/ml) no colostro de primeira ordenha de vacas leiteiras da raça holandesa .............

4 Concentraçăo de Ig A (mg/ml) no colostro de primeira ordenha de vacas leiteiras ...........................

5 Efeito da ordem de parição e ordenha sobre a concentraçăo de Ig $G$ do colos-

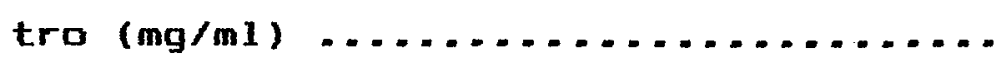

6 Densidade espeç fica e concentração final (mg/mi) de imunoglobulina dos 33 "pools" coletados para o experimento ..

7 Quantidades medias de Ig (gramas) fornecidas aos animais diariamente pelos "pools" de colostro ..................

8 Classificação da consistencia fecal ... 
10 Concentração media de protel na total sética $(g / d 1)$ nos trés tratamentos .......

11 Concentração modia de albumina serica (g/d1) nos três tratamentos ..........

12 Concentração módia de Ig G serica (mg/ m1) nos trés tratamentos ..............

13 Pesos medios (kg) por tratamentos, no periodo de 1 a 60 dias de idade. ......

14 Gantio de peso (kg) total e diario dos animais en cada tratamento, de 1 a 60 dias de idade .......................

15 Notas módias diarias de cor de fezes durante 30 dias por tratamentos .........

16 Notas médias díarias de consistência de fezes durante 30 dias par tratamentos .

17 Comparaçăo entre tratamentos no sub-periodo de 11 a 20 dias de idade para as notas modias de consistencia fecal .... 


\section{LISTA DE APENDICES}

APENDICE

Pagina

1 Concentração de PT sérica (g/d1) nas 8 unidades experimentais, até 60 dias de

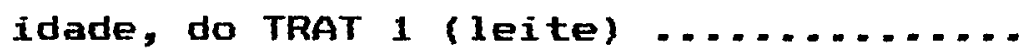

2 Concentraçăo de PT serica (g/d1) nas 8 unidades experimentais, ate 60 dias de idade, do TRAT 2 (col, iv. ao dia) ....

3 Concentraçăo de PT serica (g/d1) nas 8 unidades experimentais, ate 60 dias de idade, do TRAT 3 (col . 2V. ao dia) ....

4 Concentração de albumina serica (g/di) nas 8 unidades experimentais, até 60 dias de idade, do TRAT 1 (1eite) ......

5 Concentração de albumina sérica (g/d1) nas $B$ unidades experimentais, ate 60 dias de idade, do Trat 2 fcol. 1v. ao

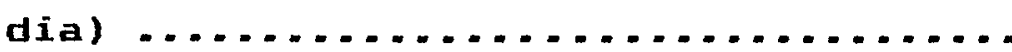

6 Concentração de albumina sérica (g/d1) nas 9 unidades experimentais, até 60 dias de idade, do TrAT 3 (col. 2v- ao

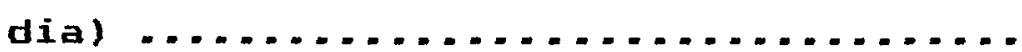

7 Concentração de Ig G serica (mg/ml) nas 8 unidades experimentais, ate 60 dias de idade, do TRAT 1 (leite) .......... 
8 Concentraçăo de Ig G sérica (mg/m1) nas 8 unidades experimentais, até $60 \mathrm{dias}$ de idade, do TRAT 2 (col 1v. ao dia) ..

9 Concentração de Ig $G$ sérica (mg/ml) nas 8 unidades experimentais, ate $60 \mathrm{dias}$ de idade, do TRAT 3 (col $2 v$, ao dia) ..

10 Composição niveis de nutrientes do concentrado fornecido para bezerros na Fazenda Agrindus 


\section{EFEITO DE DIFERENTES REGIMES DE FORNECIMENTO DE COLOSTRO POR PERI ODO PROLONGADO SODRE O COMPORTAMENTD IMUNOL SGICO E DESEMPENHO DE BEZERROS LEITEIROS}

Autora: Claudia Daniele Orientador: Prof. Dr. Raul Machado Neto

RESUMO

o comportamento imunológico e desempento foram avaliados em vinte e quatro bezerras de raça Holandesa mantidas sob diferentes regimes de aleitamento. o perído experimental compreendeu os primeiros 60 dias de vida dos animais, tendo sido analisados protel na sérica total, albumina sérica, imunoglobulinas sericas, peso vivo e diarréa. 0 delineamento experimental foi inteiramente ao acaso, em parcelas sub-divididas com trés tratamentos:

T1: Dito animais receberam diariamente uma dieta 1 iquida composta de 4 l de leite das vacas $e$ novilhas da propriedade até a desmama gradual aos 90 dias de idade.

T2: Dito animais receberam uma mistura de leite e calostro na seguinte forma: 2 de leite pela mantã e 0,81 de leite $+1,21$ de colostro à tarde, nos primeiros trinta dias de vida, sendo que apos este período receberam apenas leite até a desmama gradual ans 90 dias.

T3: 05 oito animais restantes receberan diariamente 1,41 de leite $+0,61$ de colostro pela manhã e 
igual dieta à tarde, por 30 dias até a desmama gradual aos 90 dias.

Em todos os tratamentas os animais receberam

21 de colostro de suas respectivas mães imediatamente após o nascimento, en mamadeiras, sendo esta ingestão verificada por funcionários responsáveis pelo acompanhamento dos partos. Completando 1 dia de vida, cada bezerro havia ingerido 41 de colostro de sua respectiva mãe. o colostro suplementar foi proveniente de "pools" de colostro de primeira e segunda ordenhas pós-parto de vacas e novilhas.

Ds parámetros relacionados às caracteristicas de fezes foram registrados diariamente nos primeiros 30 dias de vida. Coletou-se sangue dos animais nas seguintes idades: $3 ; 5,10 ; 15 ; 17 ; 20 ; 22 ; 25 ; 30 ; 40 ; 50$ e 60 dias. Nestas datas, alem do dia do nascimento, também realizaramse as pesagens dos animais (exceto em 3,17 e 22 dias).

A concentraçăo de anticorpos dos "pools" de colostro foi determinada a campo, com a uso de um colostrômetro. Nas análises séricas foram utilizados os metodos de biureto, eletroforese e imunodifusão radial.

Para análise estatistica dos dados foram usados metodos do programa SAS Estatistico e SENP do Ciagri.

A concentração de proteina total sérica apresentou o nível médio mais elevado $(7,83 \pm 1,15$ g/dl) por volta do 4ㅇ dia de idade. Verificou-se que o tratamento 3 
(colostro duas vezes ao dia) mostrou uma concentração de PT sérica significativamente $(p=0,05)$ maior do que no tratamento 1 (leite). Tambem verificou-se que houve diferença significativa na concentração serica de PT entre as idades experimentais $(p=0,0001)$, porém não havendo interação entre tratamento $\times$ idade $(p=0,67)$.

Em relação à concentração sérica de albumina, verificou-se que não houve diferenģa $(p=0,094)$ entre idades experimentais, bem como interaçăo tratamento x idade (p $=0,135)$, porém o tratamento 2 superou $(p=0,05)$ tratamento 1 .

Quanto a imunoglobulina serica os valores médios mais elevados $(38,85 \pm 11,38 \mathrm{mg} / \mathrm{ml})$ foram observados por volta de 3,5 dias de idade. A análise de variancia mostrou que houve diferença significativa entre as idades experimentais $(p=0,0001)$, porém não houve diferença significativa entre tratamentos $(p=0,117)$, mas devido à existéncia de interaçăo tratamento $\times$ idade $(p=0,002)$, foi feita análise de variáncia dentro de cada idade, revelando que a concentração de Ig 6 sérica do tratamento 3 foi superior fp$=0,05)$ a do tratamento 2 aos 15 e 17 dias de vida. 0 coeficiente de correlação entre PT e imunoglobulina sérica foi de 0,87 no $3^{\circ}$ dia de vida.

Quanto ao desempento, verificou-se que o nivel sefico de Ig G inicial, bem como o peso inicial ná influiram no ganho de peso total (p< 0,90 ). 0 tratamento 3 
apresentou ganho de peso significativamente maior que o tratamento $1(p=0,05)$.

Em relação à diarreia, a anâlise estatistica não parametrica mostrou que o tratamento 3 , seguido pelo tratamento 1, apresentou os melhores resultados e a tratamento 2 foi aquele onde a diarreia mostrou maior severidade durante o períado de 11 a 20 dias de idade $1 p=$ $0,01)$.

Conclui-se que a prática do fornecimento de colostro por período prolongado dividido en duas refeiçóses diárias proporcionou o melhor desempentio dos bezerros, havendo a maximização da proteção local e sistêmica contra diarreia. 


\section{EFFECT OF DIFFERENT FEEDING PROGRAMS WITH \\ SUPPLEMENTAL COLOSTRUM ON DAIRY CALVES \\ IMMUNOLOGICAL STATUS AND PERFORMANCE}

Author: Claudia Daniele Adviser: Prof. Dr. Raul Machado Neto

SUMMARY

The immunological status and performance under different milk feeding programs were evaluated in twenty-four female Holstein newborn calves. The experimental period comprised the first sixty days of 1 ife and the following variables were analysed: total serum protein, serum albumin, serum immunoglobulin, body weight and qualitative data about diarrhea caracteristics. Calves were randomly allocated to three. treatments under a splitplot statistical model:

T1: Eight calves were daily fed 4 liters of milk from the farm's herd for 90 days, when the calves were gradually weaned.

T2: Eight calves were daily fed a milk and pooled colostrum $\mathrm{mix}$ as follows: 2 liters of milk in the morning $(7: 00 \mathrm{am})$ and 0.8 liters of milk plus 1.2 liters of pooled colustrum in the afternoon (2:00 pm) for thirty days. 
After that period the animals received milk as the only feed until seaning, similarly to T1.

T3: The remaining eight animals were daily fed 1.4 liters of milk plus 0.6 liters of pooled colostrum in the morning (7:00 am) and the same diet in the afternoon (2:00 pm) for thirty days. The calves were fed milk until weaning.

The animals were fed by the use of individual plastic bottles. Each calf received its own mother's colostrum immediately after birth (2 liters). There was a perfect care with the newborn calves, that are usually attended during and after parturition in that farm. Supplemental - pooled - colostrum was collected from the first and second post-partum milkings of cows and heifers.

Also during the first 30 days of age, classification parameters of feces were daily recorded. Blood samples were collected at $3 ; 5 ; 10,15 ; 17 ; 20 ; 22 ;$ 25; $30 ; 40 ; 50$ and 60 days of age. Animals were weighed at $0 ; 5 ; 10 ; 15 ; 20 ; 25 ; 30 ; 40 ; 50$ and 60 days after birth.

Sperific - gravity was determined for each colostrum pool by a specific hydrometer for measuring Ig concentration in bovine colostrum. Blood parameters were assayed by the following methods: biuret method, electrophoresis and radial immunodifusion. The results were interpreted using statistical analysis of SAS/STAT and SENP (Ciagri) for computers. 
The highest concentration of serum total protein was found around four days of life $17.83 \pm 1.15$ 9/d1). In the first sixty days, the concentration in the T3 (colostrum fed twice a day) was significantly higher (p = $0.05)$ than in T1 (milk). The concentration was also significantly different at ages $(p=0.0001)$, but no treatment $x$ age interaction was found $(p=0.67)$.

Serum albumin levels were similar at all ages $(p=0.094)$. Treatment 2 levels were significantly higher than in treatment $1(p=0.05)$. No treatment $x$ age interaction was found $(P=0.135)$.

The highest concentration of serum immunoglobulin was found at 3.5 days of life (3B.85 \pm 11.38 mg/ml). The analysis of variance showed a significative difference in experimental ages for serum immunoglobulin levels (p $=0.0001)$, but a no significant difference among treatments was found $(p=0.117)$. However, a significative treatment $x$ age interaction $(p=0.002)$ was found, leading to a secondary analysis of variance for each experimental age. Results from this analysis showed that for T3 the Ig G concentration was higher than for T2 (p = 0.05; Tuckey Test) at the $15^{\text {th }}$ and $17^{\text {th }}$ days of 1 ife. The coefficient of correlation between serum total protein and serum immunoglobulin were 0.87 for the $3^{\text {rd }}$ day of 1 ite.

Neither initial body weight, nor initial serum Ig 6 concentration (at $3^{\text {rd }}$ day of life) influenced 
total body weight gain values $(p<0.90)$. Treatment 3 body weight gain was significantly higher than in $T 1(p=0.05)$. Non-parametric analysis showed less severe diarrhea for $T 3$ and $T 1$ from 11 to 20 days of 1 ife. In this period T2 led to the highest diarrhea severity $(p=0.01)$. A positive correlation was found between color grades and consistency grades of feces $(r=0.52)$.

Conclusion: less severe diarrhea and the best weight gain were found in calves that were twice daily fed a supplemental colostrum diet. Probably, the local and the systemic immunological protection against diarrhea pathogens were improved in these calves. 


\section{INTRODUÇÃO}

0 sucesso da criaçăo leiteira depende diretamente da sanidade dos bezerros jovens, o que pode ser obtido pela redução dos niveis de morbidez e mortalidade durante a fase inicial da vida dos animais. A minimizaçăo destes fatores pode estar aliada a práticas adequadas de manejo, especialmente logo após o nascimento, quando deve ser fornecido ao bezerro colostro de alta qualidade.

A imunidade adquirida pelo recém-nascido é denominada passiva, visto que este recebe anticorpos maternos transferidos por diferentes vias, dependendo do tipo de placenta caracteristica de cada especie. En ruminantes, o tipo de placenta existente impossibilita a passagen de anticorpos da mãe para o feto. Esta transferência ccorrerá apenas com a fornecimento de colostro ao recém-nascido, sendo a única fonte de anticorpos para o bezerro.

Embora já se conheça a necessidade da ingestão de colostro, muitos pontos ainda permanecem obscuros, principalmente no periodo pos-absortivo quando o bezerro passa por uma fase transitoria de proteçao, onde deixa de se beneficiar da imunidade passiva presente no colostro, para contar com a imunidade própria, ou seja a ativa. 
Por outro lado, extensivas investigaças admiten que nă é apenes a proteça conferida pelas imunoglobulinas sericas provenientes do colostro que pode manter os bezerros livres de infeç̧öes entericas, um dos maiores problemas em animais recém-nascidos. Provavelmente, a presença de anticorpos no lúmen intestinal, obtida atraves do fornecimento de colostro suplementar na fase pos-abortiva, tambem exerce uma certa protesão chamada de local, impedindo - ataque de patógenos ás mucosas do trato digestivo.

Assim, o presente trabaliho teve como objetivo estudar o efeito de diferentes regimes de fornecimento de colostro por periado prolongado sobre a comportamento imunológico e desempenho de bezerros leiteiros. Deu-se ênfase ao estudo da proteção adquirida passivamente e tambem daquela desenvolvida pelos animais, bem como seu efeito sobre a sanidade e desempenho referentes a ocorréncia de diarréia. 


\section{REVISAO DE LITERATURA}

\subsection{Imunidade passiva}

Os ruminantes, como todos os mamiferos, dependem de' um sistema imune produtor de anticorpos, os quais neutralizam substáncias antigênicas invasoras que atacam o organismo animal. Sabe-se que os ruminantes nascem praticamente sem anticorpos na circulaçăo sangứi nea, sendo os mesmos adquiridos por imunidade passiva atraves do colostro materno (PORTER, 1979). As imunoglabulinas protetoras 5ão ingeridas pelo recém-nascido e, juntamente com o colostro, são absorvidas intactas via mucosa intestinal nas primeiras horas de vida. Desta forma, a concentração total das mesmas no sangue aumenta significativa e abruptamente após a ingestao do colostro (BRAMBELL, 1958; JEFFCOTT, 1972). Esta imunidade denominada passiva porque é transmitida da mãe para o filho este nåo participa da sintese dos anticorpos neste processo.

Nos animais ungulados, entre os quais se encontram os ruminantes, as equiinos $e$ os sulnos, a transferencia passiva se faz no período pós-natal, em funçăo do tipo de placenta que apresentam (BRAMBELL, 1958). 
A placenta dos ruminantes chamada de sindesmocorial, onde há 5 camadas de tecido se interpondo entre a circulação materna e fetal, não permitindo a passagem de anticorpos via placenta (TIZARD, 1985). Por esta razão, nestas espécies o colostro é a única via transportadora de imunoglobulinas da mãe para a filiho, ao contrário do que ocorre em primatas e coelhos, onde os anticorpos passam livremente via placenta para o feto; en cães, gatos e camundongos, que apresentam transferéncia de anticorpos tanto no periodo fetal, quanto no pós-natal (BRAMBELL, 1958).

2.2. Importácia do colostro

0 colostro, além de fornecer as imunoglobulinas, tem também um papel nutritivo para os bezerros. Em comparaçăo com o leite, ele é mais rico em gordura, cinzas e principalmente protelnas, sendo porem mais pobre en lactose. Na tabela 1 são apresentadas as concentraçßos de nutrientes do colostro e leite. 
Tabela 1. Composição do colostro e do leite de vacas holandesas.

Constituintes Colostro Leitea

$\begin{array}{lcc}\text { Solidos Totais }(\%) & 23,9 & 12,9 \\ \text { Gordura }(\%) & 6,7 & 4,0 \\ \text { Proteina }(\%) & 14,0 & 3,1 \\ \text { Lactose }(\%) & 2,7 & 5,0 \\ \text { Cinza }(\%) & 1,11 & 0,74 \\ \text { Grav. especifica } & 1,056 & 1,032\end{array}$

Leite ${ }^{a}=2$ semanas pos-parto.

Fonte: SCHIMIDT (1971).

Schultze \& Heremans ${ }^{1}$, citados por JEFFCOTT (1972), apresentam a classificaçăo das proteinas do leite e do colostro da seguinte forma:

$$
\begin{aligned}
& \text { Protel nas especificas do leite: } \\
& \text { - casei na } \\
& \text { - } \text {-lactoglobulina } \\
& \text { - a-1actoal bumina }
\end{aligned}
$$

1 SCHLLTZE, H.E. \& HEREMANS, J.F. The protein of milk and colostrum. In: ___ Molecular Biology of Human Proteins. Amsterdam, Elsevier Publ. Co., 1966. Vol. 1, P. $832-47$. 
- lactoferrina

- protei nas especificas de menor importancia

- enzimas e constituintes não identificados

Proteinas derivadas do plasma:

- albumina serica

- imunoglobulinas - Ig $A, \operatorname{Ig} M$, Ig 6

- a1 - antitripsina

- ácido as - glicoproteina

- $\beta_{1} A C$ - globulina

A albumina não é um grupo homogeneo; $2 / 3$ desta fração equivalem a mercaptalbumina, que contém um grupo SH livre por mol. Também existe uma fração não mercaptalbumina e glicoproteínas. Além da albumina existem outras proteinas de origem serica, como o fibrinogênio, produzido no fígado e outras globulinas, como mucoprotel nas e lipoprotel nas.

o colostro tem tal importância na proteção do recém-nascido, que aqueles animais que falham em absorver os anticorpos derivados do mesmo tornam-se mais susceptiveis a doenças neonatais e à mortalidade $e$, quando sobrevivem, săo na maioria hipogamaglobulinêmicos (HUSBAND et al., 1972; EDWARDS et al., 1982).

A preocupaça en relatar as causas da mortalidade en bezerros leiteiros antes do desmame não $e$ um assunto recente. SMITH \& LITTLE (1922), já haviam consta- 
tado taxas de mortalidade de $75 \%$ a $80 \%$ dos animais recem-nascidos quando privados de colostro. Ainda hoje, são realizados levantamentos que tentam explicar e quantificar a mortalidade de bezerros, como é caso do projeto realizado por LANCE et al. (1992), en 48 rebanhos leiteiros americanos. Estes autores verificaram que diferenças no manejo e de ambiente são responsáveis por cerca de $39 \%$ da variação da taxa de mortalidade entre os rebanhos monitorados.

Uma série de trabalhos relacionam morbidez mortalidade com o processo de aquisição de imunidade passiva. GAY et al. (1965), verificaram que, en criaçbes comerciais, bezerros com baixas concentraçôes de imunoglobulinas séricas apresentaram altas taxas de mortalidade.

Da mesma forma, FISHER \& MARTINEZ (1978), comentam que os animais apenas sobrevivem à alta incidencia de diarréia nas primeiras semanas de idade em função da alta concentraçă sérica de Ig G que vierem a apresentar, ja que existe uma relativa deficiencia de Ig A serica nesta fase da vida em bezerros. Tambem, PENHALE et al. (1973) e SELMAN et a1. (1971) relataram a estreita relaçăo entre mortalidade de bezerros e a baixa concentraçăo de anticorpos sericos derivados do colostro.

NOCEK et al. (1984), observaran que bezerros privados de colostro tiveram maior indice de diarréas e maior taxa de mortalidade, $40 \%$ e $60 \%$ para dois tratamentos sem colostro inicial; alem de ganharem peso mais lentamente 
no incio da vida. Resultados semelhantes foram obtidos por RIBEIRO et al. (1983), ao verificarem que bezerros holandeses hipogamaglobulinemicos apresentaram maiores taxas de morbidez e mortalidade en situafóes de estresse, comparadas àquelas apresentadas por animais com teor de anticorpos normal, nas mesmas condiç̧es.

\subsection{Imunoglobul inas}

As imunoglobulinas (Ig) são glicoproteinas globulares, com estrutura terciaria como outros tipos de protel nas, onde as cadeias polipeptidicas dobram-se de forma compacta e esférica, encerrando toda a atividade de anticorpos circulantes.

BUTLER (1969) fez uma revisăo bastante completa sobre caracteristicas e propriedades das imunoglobulinas, apresentadas a seguir:

Ig $G$ : E a principal classe de imunoglobulinas presente no colostro de ruminantes, sendo essencial na defesa contra infecçós durante as primeiras semanas de vida. Constitui-se ainda, na principal Ig sintetizada na resposta secundaria, sendo mais abundante e difundindo-se mais rapidamente para os espaços extracelulares que as demais Ig. A IgG tem a função de neutralizar toxinas de bacterias e complexar microrganismos facilitando a fagocitose. 0 complexo bacteria-Ig G atrai celulas polimorfonucleadas, que se ligam 
a bactéria atraves de receptores celulares de superficie e fazen a fagocitose.

A sintese desta imungglobulina é regulada pela estimulação dos antigenos, perfazendo $80 \%$ do total das imunoglobulinas. A resisténcia da Ig G1 bovina à proteolise é similar à da Ig A bovina (NEWBY \& BOURNE, 1976a).

A Ig $G$ e a classe de anticorpos que existe em maior concentrą̧a no colostro de ruminantes; não s sintetizada na glândula mamária e sim transferida seletivamente da circulação sangưinea materna para o colostro (PORTER, 1979 ). Este mesmo autor e MACHADQ NETO \& PACKER (1986), relatam que a imunizaçăo passiva atraves da Ig $G$ materna influencia o "status" imunologico do recém-nascido, atuando no desenvolvimento da imunidade ativa, fazendo com que as Ig $G$ adquiridas pelo colostro modulem a resposta imune, atraves de mecanismos que inibem o crescimento de celulas produtoras de anticorpos. Ao contrário da Ig G, a Ig M estimula o desenvolvimento de tais celulas.

Ig A: Perfaz 13\% do total das imunaglobulinas séricas, e, constitui-se-na mais efetiva classe para a imunização local. E sintetizada na glândula mamária,sendo que no caso de bovinos, sua sintese f deficiente.

A IgA aparece nos fluidos do organismo na forma de dímero estável, combinada con outra protei na, sendo muito resistente à proteólise (NEWBY \& BuURNE, 1976a). Esta imunoglobulina pode impedir a aderencia do microrganismo às 
mucosas do corpo, não permitindo a colonizaçăo e infecรุณ.

Ig $M=€$ a classe mais eficiente nos casos de bacteremia, aparecendo prontamente nos quadros de infecçăo, atuando como agentes aglutinantes e citoliticos. Em bovinos este grupo representa menos de $10 \%$ das imunoglobulinas encontradas no soro e colostro (KLAUS et al.; 1969). Esta classe de anticorpos está confinada aos vasos sanguíneos e parece preceder a Ig G, na filogenia da resposta imune nos vertebrados.

2.4. Colostro e sua produça

Vários autores tên relatado o papel do colostro e a transferencia de imunidade passiva nos animais domesticos, conhecendo-se que as imunoglobulinas presentes no colostro são transferidas seletivamente do sangue materno para a glândula mamária (DIXON et al., 1961; BRANDON * LASCELLES; 1971; SMITH et a1 ., 1971; JEFFCOTT, 1972; AHLSTEDT et al $=1975)$

DIXON et al. (1961), afirmam que cerca de 700 9 de imunoglobulina são transportadas durante as três últimas semanas pre-parto, enquanto BRANDON \& LASCELLES (1971), estimaram que 500 9 de Ig são transferidas no mesmo periodo. 
Pesquisas mais recentes mastrapam que Ig Gr a principal imunoglobulina bovina que deixa $o$ sangue $e$ transferida seletivamente para a glândula mamária durante a perfodo pre-parto, principalmente nas tres últimas semanas de gestação (SASAKI et al., 1976). Este mecanismo ocasiona uma queda severa da concentraçăo sfrica dos anticorpos de ruminantes, nesta fase da vida.

Fica evidente, desta maneira, que não se pode considerar que o colostro bovino seja uma verdadeira secreção da glândula mamária, pois Ig A Ig $M$, que são encontradas em pequenas concentraçőes no colostro, săo sintetizadas na glåndula, mas parte delas também é proveniente da circulação sistêmica $e$, Ig $G$ é totalmente derivada do soro, ocorrenda, na verdade, uma "transudaçăo" serica de imunoglobulinas para a secreção láctea durante 6 a 4 semanas pré-parto (AHLSTEDT et al., 1975; SASAKI et a1., 1976).

0 mecanismo deste transporte seletivo das Igs ainda não foi totalmente elucidado. Sabe-se que a transferéncia de Ig $G$ é controlada por receptores específicos para estas imunoglobulinas existentes nas celulas epiteliais da glándula mamária $e$, tais receptores estão presentes massivamente apenas na fase de formação do colostro (HAMMER \& MosSMAN, 1978).

Esta transferência está sob controle hormonal, onde a variação nos niveis de estrogenios e progestogênios, atua direta e indiretamente na sintese (pelos plasmbitos) e 
transporte de Igs para a glândula mamária (SMITH et al., 1971).

WATSON (1980), apresenta em sua revisao um modelo para a transferéncia seletiva da Ig Gi do sangue para o alvéolo da glándula mamária, onde os receptores especificos localizados na membrana basal ou intercelular da celula acinar epitelial ligam-se aos anticorpos $G_{1}$ e nestes locais a membrana celular sofre invaginaça, destacando vesiculas transportadoras que cruzam o citoplasma das células, descarregando as Ig $G$ (en maioria) no lúmen dos alveolos, atraves da pinocitose invertida.

Em relação ao colostro, a concentração de anticorpos do mesmo apresenta uma flutuação à medida que a produção de leite se inicia, alguns dias pos-parto, a gual provoca alteraçðes drasticas também na própria composição do colostro fFOLEY \& OTTERBY, 1978; STOTT et al., 1981).

Na espécie bovina, a Ig $G_{1}$, que representa mais de $90 \%$ dos anticorpos 6 , sofre um acentuado decrescimo na sua concentraçăo na primeira semana pós-parto, quando o colostro esta se transformando en leite, apesar disto, ela se mantém como a principal imunoglobulina durante toda a lactação (LARSON et a1., 1980; NEWBY et al., 1982).

En outras especies domesticas, a Ig G, apesar de também ser o principal anticorpo do colostro, tem uma concentração insignificante no leite, sendo a Ig A (sinteti- 
zada na glándula mamárial a classe dominante desde o inicio ate o final da lactaçăo (NEABY et al., 1982). Em ruminantes, a capacidade de sintese de anticorpos pela glándula mamária não f significativa, tanto na produção de colostro como na de leite (DIXON et al, 1961 ).

Existe grande variaçăo na concentração de anticorpos do colostro bovino. QUIGLEY (1991), reuniu dados de trabalhos evidenciando tal variaçăo sob diferentes aspectos.

Nas tabelas 2,3 e 4 estao apresentados dados obtidos por vários autores em relação ao teor de imungglobulinas do colostro.

FLEENOR \& STOTT (1980), baseando-se na gravidade especifica do colostro medida com colostrometro, relacionaram as concentraçôes de imunoglobulinas do colostro e criaram uma tabela em que teores abaixo de $21,8 \mathrm{mg}$ globulinas/ml são tidos como "pobres" e acima de 49,82 mg/ml săo considerados "excelentes", enquanto que para Nocek et al. (1984), concentraçð̌es de imunoglobulinas no colostro abaixo de $45 \mathrm{mg} / \mathrm{ml}$ foram consideradas baixas e aquelas acima de 60 mg/ml foram consideradas altas. 
Tabela 2. Concentraçăo de Ig $G(\mathrm{mg} / \mathrm{ml})$ no colostro de primeira ordenha de vacas leiteiras da raça hol andesa.

Referências

$$
n^{\circ} \text { vacas }
$$

variação

conc a media

OYENIYI \& HUNTER

71

$30-42$

32

(1978)

FLEENDR \& STOTT

14

$10-136$

59

(1981)

SToTT et al.

210

36

(1979)

MICHANEK et al.

"pool"

39

(1989b)

OLSON et al.

"pool"

3

(1981)

FETCHER et al.

"pool"

22

(1983)

${ }^{b}$ BESSER et al.

"pool"

$35-151$

\section{(1985)}

a - imunodifusão radial (IDR)

b - variação de 4 "pools" e colostro individual de 11 vacas 
Tabela 3. Concentração de Ig $M(m g / m 1)$ no colostro de primeira ordentia de vacas leiteiras da raça holandesa.

Referências $n$ ำ vacas variaçăo conc.

FLEENOR \& STOTT

(1981)

STOTt et al.

210

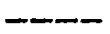

B

(1979)

OLSON et al.

"pool"

$---$

11

$4-28$

(1981)

a - imunodifusão radial

Fatores como raça, número de lactaç̧es, produção de colostro, ordenhas e manejo influem na concentração de Ig do colostro. Assim, o colostro de vacas de primeira e segunda cria menos concentrado en anticorpos que - colostro de vacas adultas (OYENIYI \& HUNTER, 1978). Este efeito se deve a menor exposição a doenças das novilhas, as quais terão menor quantidade de anticorpos especlficos séricos para transportarem para a colostro (Tabela 5). 
Tabela 4. Concentraçăo de Ig $A(\mathrm{mg} / \mathrm{ml})$ no colostro de primeira ordenha de vacas leiteiras.

Raça no vacas variaça conc. ${ }^{a}$ Referencias

hol andesa

14

$1-52$

14

FLEENOR \& STOTT

(1981)

hol andesa 210

10

stotT et al.

(1979)

Guernsey

12

$10^{b}$

MULLER \& ELLINGER

(1981)

Jersey

5

$-20^{b}$

MULLER \& ELLINGER

(1981)

\begin{abstract}
a - imunodifusão radial
b - corrigido para mg/ml usando a gravidade especifica de 1,060
\end{abstract}

Sendo o processo da formação do colostro dependente do transporte de anticorpos séricos para a glándula mamária, $e$ tal fato podendo ser influenciado por múltiplas causas, torna-se esperada a ampla variação individual no teor de imungglobulinas colostrais encontrada em vacas leiteiras. Este fator seria o primeiro a agir sobre o nivel de imunidade passiva adquirida pelos bezerros recem-nascidos. 
Tabela 5. Efeito da ordem de pariçăo e ordenha sobre a concentração de Ig $G$ do colostro (mg/ml).

Parição

Número

Ordenta

\begin{tabular}{lcccc} 
& de animais & $1^{a}$ & $2^{a}$ & $3^{a}$ \\
\hline $1^{a}$ & 28 & 30 & 24 & 14 \\
$2^{a}$ & 22 & 31 & 22 & 11 \\
$3^{a}$ & 10 & 34 & 27 & 17 \\
$4^{a}-7^{a}$ & 11 & 42 & 36 & 25 \\
media & 71 & 34 & 27 & 17 \\
\end{tabular}

Fonte: OYENIYI \& HUNTER (1978)

2.5. Transferencia de imunidade passiva em bezerros

2.5.1. Níveis de imunoglobulinas absorvidas

A meia-vida das imunoglobulinas derivadas do colostro é relativamente curta, cerca de 21 dias; entretanto influem na ocorrencia de doenças em bezerros no períado de 4 a 6 meses de vida (ROBISON et al., 1988). Estes mesmos autores comentam que animais que absorvem quantidades grandes de anticorpos, năo săo infectados sucessivamente por patógenos estando livres de doenças crónicas. Assim, utilizam as nutrientes ingeridos apenas para cresci- 
mento e desenvolvimento a inves de serem desviados para eliminação de patógenos, bem como para reparação de tecidos danificados nos processos infecciosos.

Apesar do calostro de novilhas ser mais pobre em anticorpos, ROBISON et al. (1988), tambem observaram em seu trabalio que a concentração serica de Ig nas 24 - 48 horas de vida, para bezerros nascidos de "novilhas", foi significativamente mais alta $(29,36 \mathrm{mg} / \mathrm{ml})$, do que aquela em bezerros nascidos de vacas com 3 a 6 anas de idade 124,79 mg/ml) e de varas com 7 anos de idade (26,48 $\mathrm{mg} / \mathrm{ml})$. Os autores sugeren que os bezerros que nascen de vacas mais velhas tém maior dificuldade para mamar o primeiro colostro diretamente da mãe, pois o úbere destas vacas apresenta uma conformação já distante daquela ideal, pela idade mais avançada, diferentemente da conformação do úbere de vacas ainda jovens. Este fato pode ocasionar um atraso na primeira mamada por mais de 6 horas pss-parto, pelos bezerros nascidos de vacas mais velhas.

VENTORP \& MICHANEK (1992), realizaram um trabalio tentando determinar a influência da distancia do úbere até o chão e do formato das tetas, na facilidade do bezerro encontra-1as e na idade pos-parto da primeira mamada. Neste estudo, atraves de várias medidas de distancia entre tetos, diametro e comprimento de tetos, usando modelos matematicos, verificaram que bezerros nascidos de vacas ou novilhas com úberes muito baixos, com distancias do úbere ao 
chão $\leq 45 \mathrm{~cm}$ tiveram dificuldades, atrasando a primeira mamada de colostro. Para que tal fato não ocorra, animais nascidos de mães com este tipo de úbere deven ser ajudados a mamar ou devem receber aleitamento artificial para garantir a obtençăo ideal da imunidade passiva.

Os mesmos autores verificaram, tambem, que 0 tamanho da teta, conformação e localizaçăo da mesma não interferiram no sucesso dos bezerros em fazer a primeira mamada o mais cedo possivel, o que parece ser contraditório; porém, afirmaram que dificil distinguir entre os efeitos por tais caracteristicas de úbere, tetos e bicos de tetos e, efeito da habilidade natural do bezerro en realizar a primeira mamada.

NOCEK et al. (1984), detectaram que o fornecimento de colostro com altos teores de imunoglobulinas nas primeiras toras de vida nåo apresentou vantagens no ganho de peso dos 5 a 11 dias e dos 5 a 45 dias de idade dos bezerros analisados. Contudo, este efeito foi positivo até o quarto dia de idade, onde houve perda de peso para bezerros alimentados com colostro pobre em anticorpos. Os animais privados de colostro nas primeiras horas de vida tiveram as piores taxas de ganho de peso até 45 dias de idade.

Também EDWARDS et a 1. (1982), não encontraram correlação entre os niveis sericos iniciais de anticorpos $(48$ horas de vida) e ganto de peso diário até o desmame. Os autores afirmam que isto ocorre en função do ní vel inicial de 
anticorpos sericos estar muito acima dos niveis necessários, - que se obtém com ótimas condiçoes de manejo dos bezerros, não havendo influência, neste caso, sobre o ganho de peso.

Já ROBISON et al- (1988), encontraram um efeito positivo $(p<0,01)$ da concentraçăo serica de imunoglobulinas nas $24 \mathrm{~h}$ a $48 \mathrm{~h}$ de idade sobre a taxa de ganho de peso do nascimento até 180 dias, sendo este efeito mais intenso no período de 70 a 105 dias. Neste mesmo trabalho, 1000 bezerras holandesas apresentaram média de $25,71 \mathrm{mg} / \mathrm{m} 1(\mathrm{DP}= \pm 19,06)$ para a concentração sérica de Ig nas 24 a $48 \mathrm{~h}$ de vida, sendo a amplitude de variação de 0,05 a $108,27 \mathrm{mg} / \mathrm{ml}$. Admitiram tambem, que niveis $\leq 12 \mathrm{mg} / \mathrm{ml}$ na mesma idade, tornaram os animais hipogamaglobulinêmicos, o que representou a causa de $44,2 \%$ das mortes ocorridas até 180 dias de idade.

Os niveis de anticorpos absorvidos pelo recém-nascido, podem atingir variaç̧es muito grandes, mostrando resultados diferentes nos diversos trabalhos apresentados sobre absorção de imunaglobulinas do colostro. BRIGNOLE STOTT (1980), encontraram valores de 0 a $63 \mathrm{mg} / \mathrm{ml}$ de Ig $G$ serica em 983 bezerros leiteiros apos aleitamento natural, até 24 horas de vida, sendo o valor médio apresentado de $11,3 \mathrm{mg} / \mathrm{ml}$. Verificaram, tambem, que 42\% dos bezerros não absorveram as imunoglobulinas, ao mamarem diretamente de suas mães. 
Já EDWARDS et al.(1982), relatam níveis de anticorpos sericos nas 48 horas de vida, de $60,08 \mathrm{mg} / \mathrm{ml}$ em 90 bezerros, os quais tiveram acesso an colostro nas primeiras 6 horas de vida $e$ de $33,80 \mathrm{mg} / \mathrm{ml}$ para 29 animais que foram ajudados a mamar colostro após 6 horas de vida, valores considerados acima do mínimo necessário.

BESSER et a1. (1985), verificaran concentraçżes sericas de Ig G1 nas 48 horas de vida, valor ajustado, entre 9,1 e $21,2 \mathrm{mg} / \mathrm{ml}$ para 225 bezerros leiteiros, onde o pico de Ig Gi no sangue correlacionou-se positivamente $r=0,751$ ( $p<0,001)$ com a concentração de Ig Ga presente no colostro. Enquanto Le BLANC et al. (1992), trabalhando com transferencia de imunidade passiva em potros, obtiveram uma correlação positiva de $r=0,81$ (p $(p, 0001)$ entre a concentraçăo de Ig $G$ sérica inicial e a concentraçăo de Ig $G$ do colostro.

CRUYWAGEN (1990), estudando o efeito da formação do coágulo abomasal de colostro na absorção de Ig 6 pelos bezerros recem-nascidos, obteve valores de Ig $G$ no plasma, 6 horas após ingestão do colostro, de $11,6 \mathrm{mg} / \mathrm{ml}$, para colostro que coagulou no abomaso e $6,6 \mathrm{mg} / \mathrm{ml}$ para colostro sem có́gulo $(11$ de colostro fornecido pós-parto) $e$, níveis de $21,2 \mathrm{mg} / \mathrm{ml}$ para colostro coagulado e $12,9 \mathrm{mg} / \mathrm{ml}$ para colostro não coagulado $(2) 1$ de colostro fornecidos pós-parto). O autor concluiu que a formação do cóagulo favorece a absorção das imunoglobulinas, que são absorvidas 
rapidamente com a fraçåo soro do colostro e escapam da digestão gástrica.

Em outro trabalho, AYERS \& BESSER (1992), encontraram niveis médios de 15 a $18 \mathrm{mg} / \mathrm{ml}$ de Ig Gi sérico, em 40 bezerros, nas 12 horas pós alimentaçăo com três tipos de "pools" de colostro tratados com diferentes agentes alcalinizantes e un "pool" controle, onde a absorção de Ig Gi, colostral não foi afetada pelos tratamentos efetuados no calostro e, nem pelos diferentes "status" de gases ou pelo equilibrio de ácido/base do sangue.

2.5.2. Fatores que afetam o processo de absorção

0 mecanismo de absorção doś anticorpos do colostro se processa de acordo com a descriçăo de ARGENZIo (1984): (a) adsorção da macromolécula na microvilosidade da célula epitelial do intestino delgado (11eo); (b) apos uma certa quantidade de macromoleculas serem adsorvidas, a concentração e tal que ocorre invaginação da membrana, formando vesiculas que contém as macromoléculas dentro da celula absortiva (com gasto de ATP); (c) este fagossona migra para a região supra-nuclear, onde coalesce com o lisossoma, originando o fagolisossoma. Pode ocorrer digestão intracelular, mas as macromoléculas escapam, nas primeiras horas de vida e migram para a regiao basal da célula onde: (d) ธăo excretadas por endocitose invertida; (e) passam para 
o espaço intercelular e (f) atingem o sistema linfatico e a circulação sangurnea, atraves do duto torácico.

Segundo KRUSE (1983), apenas por algumas horas aposs o nascimento existem condiçōes ideais para absorçăo de anticorpos pelo bezerro, tais como: pequena produção de HCl no estómago, atividade mínima da pepsina gástrica, presença de um fator inibidor de tripsina no colostro, que protege as anticorpos da digestão por enzimas pancreaticas e, tambóm baixa atividade proteolitica da mucosa intestinal. Estes fatos demonstram que, no animal recem-nascido, pela existência de células epiteliais ainda imaturas no trato digestivo, altamente vacuoladas, torna-se possivel a absorção de macromoleculas intactas do lúmen para a circulaçăo sanguínea. 0 autor esclarece, tambem, que a absorção não seletiva, onde uma gama de protef nas homslogas e heterologas podem ser absorvidas.

Fatores como a concentraçăo de Ig do colostro, bem como a quantidade total de Ig G ingerida por unidade de peso vivo, podem influenciar a absorção de Ig $G$ pelo recém-nascido. Assim, parece que a concentração de Ig do colostro tem maior importáncia do que a quantidade total de colostro fornecida. A eficiéncia de absorção para Ig M decresce à medida que a quantidade absorvida aumenta (BusH \& STALEY, 1980; BUSH et al., 1973). 
Da mesma forma, BESSER et al. (1985), encontraram correlaçbes negativas entre a eficioncia de absorfăo e a massa de imunoglobulina $G_{1}$ fornecida aos bezerros recém-nascidos, o que sugere a existencia de uma limitaçăo fisiológica à transferencia de grandes massas de Ig Gi para o soro, dado um certo volume de colostro.

Vários autores têm recomendado o fornecimento de pelo menos $5 \%$ do peso vivo do animal em colostro, nas 5 a 6 primeiras horas de vida (KRUSE, 1983; DONOVAN et a1.; 1986).

Devido a acontecimentos como queda dratica na concentração de anticorpos do colostro apos a primeira ordenha e outros diretamente ligados ao término da permeabilidade intestinal às macromoleculas intactas, o atraso no fornecimento do primeiro colostro, pode comprometer 0 "status" imunologico do recém-nascido (DEVERY et al., 1979; EDWARDS et a1., 1982).

Os fatores que regulan este "fechamento" da absorção intestinal de macromoléculas intactas logo apss as primeiras horas de vida ainda não foram totalmente definidos, porém, jé se conhece a influśncia endócina (corticosteroides), aliada ao desenvolvimento e maturação das células do trato digestivo, com ativação de suas enzimas, bem como situaçoses de estresse que atuam sobre este mecanismo biologico (BUSH \& STALEY, 1980; KRUSE, 1983 ). 
Existem resultados controvertidos a respeito do tempo e taxa para absorçăo das diferentes classes de Ig. Assim, PENHALE et al. (1973) e LOGAN et al. (1978), encontraram diferenças significativas, enquanto STOTT et al. (1979), não observaram variação em tais parámetros.

Já EDWARDS et al- (1982), afirmam que falhas na absorção de anticorpos do colostro pelo recén-nascido devem-se a problemas no manejo e não à suposta seletividade fisiológica individual para o mecanismo de absorçăo. Tambem BESSER et al. (1985), não encontraram nenhuma indicaça de mecanismos seletivos para absorção de imunoglobulinas en seu trabalho.

Relacionando os tipos de dietas liquidas fornecidas aos bezerros recém-nascidos e sua influência na absorção de anticorpos, existem experimentos variando as condiçช̃es de aleitamento, camo o de MICHANEK et al. (1989c), onde se forneceu colostro a bezerros leiteiros nas B, 16 e 24 horas após a mascimento, sendo que um grupo de animais recebeu leite com 30 minutos de vida. Os autores verificaram que a ingestão de leite comum antes da ingestão do primeiro colostro nåo alterou a permeabilidade intestinal para os anticorpos, não sendo constatada diferença significativa no ní vel de Igs séricas absorvidas.

Ainda foi definido, com este trabalho, que em relação ao "fechamento" intestinal para transmissão das macromoleculas não houve diferença na transferencia de 
anticorpos para o sangue quando se forneceu o primeiro colostro a bezerros com 30 minutos, 1 hora, 8 horas, 16 horas ou 24 horas de vida. Todavia, na segunda, terceira e quarta refeiçes de colostro, espaçadas por $B$ horas, os animais que haviam mamado o primeiro colostro mais cedo absorveram maiores quantidades de macromoleculas. Grande parte désta absorção ocorire na primeira alimentaçăo, indicando que um nível básico da capacidade de transmissão é mantido durante as primeiras 24 horas de vida, e que, sob certas condiçbes, uma imunização passiva aceitável pode ser obtida em bezerros que recebem o colostro até 24 horas de vida. Desta maneira, - "fechamento" intestinal parece se iniciar com a primeira refeiço substancial de colostro feita dentro das 8 primeiras horas apos a nascimento e vai evoluindo progressivamente (MICHANEK et a1., 1989a; MICHANEK et a1., 1989b).

Quanto à forma de aleitamento, BESSER et al. (1991), detectaram falhas na transferencia passiva (menos de $10 \mathrm{mg} / \mathrm{ml}$ de Ig Gi serica as 46 horas de vida) em $61,4 \%$ dos bezerros analisados em um rebanho com manejo de aleitamento natural e em $19,3 \%$ dos bezerros de outro rebanho, aleitados com mamadeiras. Definiu-se que o fator que mais influiu na absorção de anticorpos para os bezerros em aleitamento artificial foi o volume de colostro fornecido, afetando a quantidade de Ig $G_{1}$ fornecida ao bezerro. 
2.6. Transiçăo da imunidade exógena para imunidade endógena

Os bezerros nascem com teores insignificantes de gamaglobulinas no soro (Mccor et al., 1970). Apos a ingestão do colostro, essa concentração aumenta significativamente (BRAMBELL, 1958).

Vários autores, observaram o pico de concentraçăo para as imunoglobulinas no soro de bezerros, apos diferentes periodos da ingestao do primeiro colostro, como é o caso de Mccoy et al. (1970); BuSH et al. (1971): HUSBAND et al. (1972); RIBEIRO et al. (1983), que detectaram a maxima concentração de anticorpos no soro por volta de 24 horas após o nascimento. Já LDGAN et al. (1978), detectaram - pico entre 15 a 48 horas de vida e, para picos de concentração sérica de Ig Me Ig A, HuSBAND et al. (1972), verificaram a ocorrência na decima segunda hora apos a ingestão do primeiro colostro.

Após atingir a concentraçăo máxima, o nível de imunoglobulinas vai caindo gradativamente devido ao catabolismo protéico. Este comportamento foi observado por TENNANT et al. (1969), BUSH et al. (1971), HUSBAND et al. (1972) e RIBEIRO et al. (1983).

Segundo PORTER (1972), a vida media das imunoglobulinas adquiridas passivamente $\&$ de 20 dias para Ig G, quatro dias para Ig Me dois dias para Ig A. HUSBAND et a1. (1972), atraves de regressăo, encontraram resultados 
semelhantes, estimando a vida media para Ig Gi em 16 dias, para Ig G2 em 32 dias, para Ig M em 4 dias e para Ig $A$ em 2 dias e meio. Após este períado de declinio, verifica-se em algumas semanas uma elevação gradativa da concentraçăo sérica das imunoglobulinas, devido à sintese endógena de anticorpos. Segundo HusBand et al. (1972), a produção endógena de Ig 6 e Ig $M$ se inicia entre 8 a 16 dias após 0 nascimento e a de Ig A em torno dos 64 dias. Entretanto, RIBEIRO et al. (1983), verificaram que o decréscimo de anticorpos séricos em bezerros holandeses permaneceu até os 21 dias de idade.

A produçăo endógena de anticorpos $\&$ uma resposta às influéncias antigénicas do meio ao qual o recém-nascido está exposto. Vários autores, como HUSBAND \& LASCELLES (1975), LOGAN et al. (1974) e RIBEIRO et al. (1983), observaram que bezerros que adquiriram uma menor quantidade de anticorpos passivos iniciaram a sintese endógena de imunoglobulinas antes daqueles que absorveram quantidades mais elevadas de anticorpos, sugerindo um efeito inibidor das imunoglobulinas maternas no sistema imune do bezerro recém-nascido.

Durante a fase de transição da imunidade exógena para endógena, o animal ten niveis mínimos de anticorpos, o que o torna mais susceptivel a infeç̧oes (HUSBAND et al , 1972). 
A protelna serica em bezerros, a partir do nascimento, segue um padrão de variaçăo semelhante ao das imunoglobulinas. Ao nascer o bezerro apresenta os niveis mais baixos de proteina total, a qual atinge um pico de concentraçăo aos 4 dias de vida com a ingestão de colostro $e$ começa a diminuir gradativamente ate se estabilizar (TENNANT et al., 1969; FAGLIARI et al., 1983; NOCEK et al., 1984).

NOCEK et al - (1984), observaram uma correlaçăo positiva entre proteina total serica e Ig 6 sérica no periodo de 12 horas a 11 dias após o nascimento, apenas após a ingestão de colostro. Das $12 \mathrm{~h}$ até 4 dias, a correlação apresentou $r=0,84$, sendo a mais baixa aos 11 dias de vida, $r=0,69$, indicando que esta relação começa a diminuir com o tempo.

2.7. Diarréa e proteça

2.7.1. Consideraçชes gerais

A diarréia uma das doenças mais frequente em animais jovens, afetanda-os na dependencia de fatores ambientais e do "status" imunológico dos mesmos (sAif et al., 1983).

Alguns autores tém verificado altas taxas de mortalidade em bezerros, causadas por diarreia (LINNABARY * DEAN, 1983; MORGAN, 1986; BELLINZONI et al., 1989). 
GUYTON (1978), relata que a perda acentuada de agua e sais, secretados pela mucosa intestinal durante a diarreia, pode provocar a morte do animal em um dia. 0 mesmo autor, afirma ainda que a falta de uma terapia, a qual possa repor rapidamente os liquidos e eletrolitos perdidos, leva a uma taxa de mortalidade no rebanho superior a $50 \%$.

MORGAN (1986), afirma que no Reino Unido 3\% dos bezerros comercializados morrem de diarréia causada por vários agentes. Trinta por cento dos bezerros doentes poderiam ser recuperados, o que representaria um custo de 5 a 101 ibras por bezerro criado, sendo os gastos representados por tratamento veterinário, redução de ganho de peso, mudanças no manejo e perdas por mortalidade.

Já BRAUN \& TENNANT (1983), encontraram taxas de mortalidade, para bezerros leiteiros nos Estados Unidos, de 30\%, sendo a mesma en torno de $47 \%$ para bezerros hipogamag lobulinêmicos. Enquanto LINNABARY \& DEAN (1983), no mesmo pals, verificaram taxas de mortalidade entre 8 a $80 \%$; sob várias condiçßes, sendo a diarréia a principal causa das mortes. Estes autores ainda afirmam que para bezerros privados de colostro, a mortalidade pode variar de 70 a $90 \%$ devido a infeç̧ōes entericas.

Na Argentina, BELLINzoni et al. (1989), trabalhando com bezerros jovens, verificaram que o estado de morbidez causado por diarreia pode variar entre 90 e $100 \%$ a taxa de mortalidade, por tal doença, variou de 1 a $20 \%$. 
A diarreia pode ser considerada um quadro clinico em que o animal apresenta um fluxo mais rapido do bolo fecal pelo trato digestivo. Tal fato se deve nå só à absorção comprometida de agua, sais e nutrientes pelas vilosidades da mucosa intestinal, como também aumento na secreção de 11 quidos para a lúmen, havendo, assim, estimulação dos movimentos peristalticos, resultando em diarréia (SAUNDERS \& WGGINS, 1981; RUMESSEN, 1988).

As causas destes distúbios são variadas, havendo uma certa dificuldade em determina-1as, o que complica sobremaneira o tratamento da doença (SAIF et al., 1983).

A etiologia da diarréia é muito complexa, onde uma gama de virus, bactérias e protozórios podem ser identificados como agentes causais, além de haver interação entre tais patógenos, que podem ocorrer conjuntamente no animal (HALL et al., 1988; MORGAN, 1990).

Sendo uma doença com causas multifatoriais, problemas não patogénicos também podem influir no processo, como fatores químicos ou mecánicos presentes na dieta, o que levaria a predisposiçăo da multiplicaçăo indesejável de certos microrganismos no trato digestivo, podendo ocasionar infecç8̃es (HALL, 1987 ).

Todavia, qualquer fator, patogênico ou não, que leve a um processo inflamatorio pode danificar os enterocitos. Os produtos da inflamaçăo, liberados por 
Colulas do sistema imune para proteção do organismo, podem induzir à secreção de fluidos pelas celulas intestinais, agravando a diarréia. Porém, maiores estudos são necessários para caracterizar tais mecanismos (BANWELL, 1990 ).

2.7.2. Ação dos patógenos causadores de diarréia

Apesar de conhecidos vários patógenos e suas variaçßes na ocorrência de diarréia, segundo MORGAN (1986), 30\% dos casos não têm agentes causais identificados.

Existem várias bactérias que causam diarréia, como Salmonella e Escherichia coli, sendo a segunda especie mais importante (TZIPORI, 1981).

Segundo ROWE \& GRoss (1983), são inúmeros as tipas de E. coli que causam diarréa. As mais contecidas sao as enterotoxigenicas, as quais produzem toxinas que estimulam a secreça intestinal via mensageiros intracelulares, como AMPciclico e GMPcíclico, inibindo a absorção.

Para que haja diarréia, as bactérias patogênicas precisam se fixar no epitélio para colonizar o mesmo, 0 que é garantido pela presença de uma fímbria protéca filamentosa, un antigeno que se liga a receptores especificos na célula intestinal (ACRES, S.D., 1985). Em ruminantes esta aderencia feita pelo antigeno K99 (LINGGOOD \& PORTER, 1979; MOQN \& MCDONALD, 1983). Alem da aderencia, colonizaçăo e produção de toxinas, as $E$. coli danificam as 
microvilosidades intestinais, tornando-as atrofiadas, inibindo a absorçăo de liquidos e nutrientes (GUERRANT et al., 1990).

Os danos causados por $E$. coli săo verificados, preferencialmente, nos tres primeiros dias de vida dos animais, sendo severos, porém de curta duração (MaRIN et al., 1978).

Existem outros tipos de bactérias além da $E$. cali enterotoxigênica, como as enteroinvasivas, que invadem os enterócitos e causam ulceraçóes no epitêlio e as enterapatogenicas, cujo mecanismo de ação pouco se conhece (DKERMAN, 1987).

No caso de diarréias causadas por virus, existem pelo menos 8 vírus já identificados, além dos grupos e sub-grupos (SAIF \& SMITH, 1985; LUCCHELLI et a1., 1992).

Os vírus de maior ocorrencia săo Rotavírus e Coronavirus, ambos geralmente associados ao protozoário Cryptosparidium (TZIPORI, 1981).

Ds maiores problemas com Rotavirus, Cryptosporidium e Coronavíus ocorrem do quarto ao decimo quinto dia de vida, sendo que para o último patógeno a segunda semana de vida e mais critica (WOODE \& BRIDGER, 1975; MORIN et al., 1978).

Já SAIF \& SMITH (1985) relatam que as infeç̧̧es intestinais viróticas ocorrem dos 7 ans 21 dias de 
idade, sendo que surtas mais precoces se devem ao fornecimento de colostro com pequenas quantidades de anticorpos, falha na transferencia de imunidade passiva, ou até à alta viruléncia e infestação com esses virus.

Os danos ao epitelio intestinal causados por virus e Cryptosparidium podem ser descritos da seguinte forma: formaçăo de bolhas nas vilosidades; fusăo das células epiteliais, que perdem suas membranas intercelulares; microvilosidades curtas e desordenadas; hipertrofia do núcleo celular e das criptas intestinais; atrofia das vilosidades por esfoliação e perda das celulas epiteliais (ANDERSON, 1982; SAIF \& SMITH, 1985; HALL, 1987; HALL Et a1., 1988).

No caso de infeç̧̃o subcilnica por Rotavirus, os sintomas de diarreia săo fracos, podendo ocorrer uma proteção contra infeç̧ßอs posteriores mais severas com o mesmo patógeno (MURAKAMI et al., 1990).

Recentemente, THORNG et al. (1992), desenvolveram un teste rapido e sensivel de "ElISA" para deteç̧ão simultánea de antígenos de coronavírus bovino, Rotavirus do grupo A E Escherichia colik 99 nas fezes de bovinos, todas patógenos causadores de diarréia. 
2.7.3. Imunidade passiva sistémica $\times$ proteção local

Os linfócitos, celulas envolvidas na resposta imunológica, dividem-se em linfócitos $B$ e linfócitos $T$. As células B sintetizam os anticorpos, que liberados, ligam-se especificamente ao antigeno provocando uma sêrie de reaçôs que desencadeiam a resposta imune, tais como: aglutinação dos antigenos; opsonizaçăo, facilitando a fagocitose do complexo antígeno-anticorpo pelos macrófagos; ativação das proteinas complemento, que levam à liberação de aminas vasodilatadoras, estimulando a resposta inflamatória, além de sua atividade quimiotática, que causa acúmulo de células fagociticas na região infectada e atividade de lise de bactérias. O complemento também participa da opsonização, ligando-se ao anticorpo-antigeno e sendo facilmente reconhecido pelo macrofago fagocitador. Tais mecanismos foram discutidos na revisão feita por BOURNE \& NEWBY, 1981.

Já os linfócitos $T$, alem de produzirem substancias semelhantes a anticorpos, produzem também uma serie de outros compostos importantes no mecanismo de defesa mediado pela celula, além de regularem a resposta exercida pelos anticorpos atraves da supressão ou estimulação das células B. Tais substânias sao as linfocinas, que estimulam a açăo dos macrófagos, maximizam a quimiotaxia $e$ inibem a replicaçăo viral. Tais células tambem podem apresentar o efeito citotóxico, destruindo diretamente as células 
invasoras ou pela liberação de citotoxinas, as quais lisam o antigeno, ou ainda com a ajuda dos anticorpos, sendo que neste caso, a célula citotóxica depende do anticorpo para destruir o antígeno (BOURNE \& NEWBY, 1981).

Os mesmos autores explicam que no sistema imune do organismo, os linfocitos encontram-se em "pools" recirculantes do sangue, onde uma população migra entre o baço e nodulos linfaticos periféricas, sendo responsável pela imunidade sistemica e outra populaçắ de celulas migra entre trato digestivo, glándula mamária, trato respiratorio e urinário, sendo responsavel pela proteçá local das mucosas corporais.

Todas as respostas imunologicas descritas anteriormente efetuadas por linfócitos, ocorrem tanto sistêmica, como localmente, porém existem algumas particularidades do sistema imune local. Classicanente, o anticorpo responsável pela proteção local da mucosa 6 o Ig A, porem Ig A $\mathrm{Ig} M$ podem atuar tanto na proteç̃o sistemica, como na proteção local (MACH \& PAHUD, 1971 ; ROBERTSON \& CEBRA, 1976; PORTER, 1979;-BUURNE \& NEWBY, 1981; SHELDRAKE \& HUSBAND, 1985; SAIF \& SMITH, 1985).

As imunoglobulinas são sintetizadas e secretadas por células locais, ganhando o lúmen intestinal ao passarem pela mucosa, sendo a própria sensibilização local do intestino que desencadeia a resposta imunologica da mucosa (THOMAS \& PEMBERTON, 1980; BOURNE \& NEWBY, 1981; SHELDRAKE \& 
HUSBAND, 1985). As imunoglobulinas tambem podem gantar os vasos linfáticos e pelos dutos linfáticos chegar à circulaçăo sanguínea e aparecer em orgãos bem distantes de sua origem (THOMAS \& PEMBERTON, 1980; SHELDRAKE \& HUSBAND, 1985).

No intestino, as celulas M das placas de Peyer szo sensibilizadas por antígenos do lúmen, fazendo com que os linfócitos existentes nos follculos das placas de Peyer se dividam e se desenvolvam, seguindo-se a migraçăo destes linfócitos maduros, via circulaçăa sanguínea, que podem retornar, posteriormente, ao intestino, ou no caso de fémeas prenhes ou lactantes, glándula mamária, onde vão exercer as funçôs imunológicas de proteção, havendo uma ligação entre os sistemas imunes locais do intestino e da glândula mamária (BOURNE \& NEWBY, 1981).

A Ig $A$ pode apresentar vários mecanismos para inativar os antígenos, porém, o papel que já está comprovado \& impedimento da adesao de bactérias patogenicas à mucosa intestinal, evitando, assim, a colonização e fazendo com que outros mecanismos internos sejam ativados maximizando a resposta imunologica local (HALL, 1986).

Em relação à imunidade passiva, ainda não estão bem definidos os mecanismos que podem interferir na ocorréncia de infecçB̈es entéricas (SAIf et al., 1983). Conhecemos, porém, que os sistemas imunológicos local $e$ sistémico são distintos, sendo que a imunização da mucosa resulta em pequena ativaçăo da resposta sistêmica e, por sua 
vez, a imunizaçăo parenteral produz pouca resposta do sistema imune local, no entanto, existe alguma ligaçao entre tais sistemas interferindo na ocorrencia de doencas entericas o que deve ser mais arduamente pesquisada (BOURNE \& NEWBY, $1981)$.

Vários estudos têm documentado a'importáncia da presença contínua de anticorpos locais (imunidade lactogenica) dentro do lúmen intestinal para uma efetiva proteção contra enterites provocadas por vírus (SNODGRASS \& WELLS, 1976; SAIF et a1., 1983; DAUVERGNE et a1-, 1983; CASTRUCCI et a 1., 1989; TSUNEMITSU et a1., 1989).

Porém, os anticorpos do sangue, embora não essenciais para proteção dos enterócitos, parecen participar da mesma, se existentes em grandes quantidades (SNODGRASS \& WELLS, 1976). Foi verificado por BESSER et al. (1988b), que anticorpos passivas podem passar da circulação sangul nea para a mucasa intestinal. Estes autores constataram que em bezerros que absorveran passivamente 1009 de Ig G1, cerca de 1 a 49 deste anticorpo retornavam ao intestino diariamente durante as duas semanas apos absorção, sendo que este processo pode ser maximizado se a concentração de Ig 6 absorvida passivamente for alta $e$ tambem pode acorrer em animais adultos. Esses anticorpos passivos podem ter papel fundamental na proteção da mucosa intestinal, desde que NEWBY \& BOURNE (1976a) comprovaram a resistencia de Ig $G$ à proteólise, similarmente à Ig A. 
Desta forma, vários autores confirmaram que o fornecimento de colostro de alta qualidade, permitindo mais que $30 \mathrm{mg}$ de Ig/ml de soro sangüíneo, diminuiu a incidência e/ou severidade das diarréias infecciosas ocorridas em bezerros jovens (MCNULTY et al., 1976; McGUIRE et al., 1976; SNODGRASS \& WELLS, 1978; BRAUN \& TENNANT, 1983; LINNABARY \& DEAN, 1983; NOCEK et a1., 1984; MCNULTY \& LQGAN, 1987).

\subsubsection{Colostro suplementar}

BRIGNOLE \& STOTT (1980), verificaram altas taxas de sobrevivencia $(86,7 \%)$ entre os bezerros agamaglobulinemicos. Os autores propsem que tal fato ocorreu em razão da proteção imunológica intestinal, exercida pelo colostro adicional fornecido aos animais. Esta informaça encoraja o fornecimento de colostro adicional para fins profilaticos, mesmo quando a fase de permeabilidade intestinal às imunoglabulinas já tenha cessado.

SNODGRASS \& WELLS (1978), demonstraram que existem duas maneiras peilas quais o colostro pode proteger os animais contra diarréia causada por Rotavíus. Uma delas 0 fornecimento de quantidades adequadas de colostro de boa qualidade aos animais no primeiro dia de vida, o que confere proteçá pelo menos ate 2 dias de idade. Uma proteção mais longa e efetiva pode ser obtida provendo-se quantidades menores de colostro, continuadamente, como parte da dieta líquida 
dos animais, o que poderá protegê-los contra a doença pela tempo em que o colostro continuar a ser fornecido.

E conhecido o aspecto endemico das infecçóses por Rotavirus: por essa razão, a maioria dos animais adultos em criaçôes comerciais apresentam anticorpos contra este patógeno, circulantes no sangue. Estes anticorpos especificos estão presentes en quantidades razoáveis no primeiro colostro retirado de vacas e ovelhas após a parição, porém seus níveis são insignificantes dentro de tress dias pós-parto lwOODE et a1., 1975; SNODGRASS \& WELLS, 1978; TSUNEMITSU et al.; 1989).

Para tornar o colostro mais concentrado em anticorpos especi ficos contra vi rus e bactérias, uma técnica foi desenvolvida pelos pesquisadores para maximizar a proteção passiva sistêmica e local conferida pelo colostro: a vacinação das vacas prenhes contra agentes especificas causadores de diarréia. Tal método eleva o número de anticorpos $G$ sericos especificos na vaca, havendo um transporte seletivo dos mesmos para o colostro. fornecimento deste colostro imune no primeiro dia de vida maximiza a proteção passiva sistemica, e a continuação deste fornecimento após o "fechamento" da mucosa intestinal viabiliza a proteçá local (BUSH \& STALEY, 1980; THOMAS \& PEMBERTON, 1980; SAIF et a 1., 1983; DAUVERGNE et a1., 1983; SHELDRAKE \& HUSBAND, 1985; BELLINZONI et a1 , 1989; CASTRUCCI et a1., 1989). 
Desta forma, aliando-se as práticas de fornecimento de colostro até as primeiras 24 horas de vida e posteriormente de forma suplementar, pode-se conseguir uma proteção maior para o animal jovem, livrando-o da diarréia.

Estudos ainda estão sendo efetuados para o aperfeicoamento das vacinas, principalmente contra virus. Existem relatos demonstrando que a variação na via de aplicação, no agente utilizado para preparar a vacina e nos adjuvantes podem interferir na efićcia da imunização, tanto contra bacterias, como contra virus (PORTER et al., 1975; McNultY et al., 1976; De LEEUW et al., 1980; MYERS \& SNODGRASS, 1982; ACRES, 1985; BELLINZONI et a ., 1989).

Alguns trabalhos não obtiveram sucesso usando vacinaçăo oral dos bezerros recem-nascidos contra Rotaví rus: entretanto para $E$. coli os resultados foram satisfatorios (PORTER et al., 1975; De LEEUW et al., 1980).

De LEEUW et al. (1980), propóem que a imunização oral dos bezerros recém-nascidos com vacinas usando vírus vivo atenuado pode não ter dado resultado pela presença de anticorpos derivados do colostro, os quais neutralizariam o virus da vacina. As măes são infectadas naturalmente em condiçß̄es de campo, o que leva à presença de anticorpos especificos no colostro. Ds mesmos autores ainda afirman que os bezerros recém-nascidos nåo têm o sistema imune ativo para responder à vacinaçăo. 
Também MOON \& McDONALD (1983), verificaram que a vacinaçăo oral de vacas prenhes nå foi efetiva para elevar os niveis de anticorpos especificos contra o antigeno $k 99$ de E. cali, no colostro e leite destes animais.

Porém, muitos pesquisadores tém relatado que as vacas imunizadas pre-parto con vacinas experimentais produziram quantidades mais que suficientes de anticorpos sericos especificos, os quais foram transportados da corrente sangưinea para as secreçóes lácteas, conferindo proteção passiva sistémica máxima aos bezerros contra diarréia causada por Rotavírus bovino, além de proteçăo local pela alimentação suplementar com este colostro e leite de animais imunizados (SNODGRASS et al,, 1980; SAIF et a1., 1983; SAIF \& SMITH, 1985; BELLINZONT et a1,, 1989; CASTRUCCI et al., 1989; TSUNEMITSU et al., 1989).

05 resultados obtidos por SAIF et al. (1983), demonstraram que com o término da alimentaçăo com colostro por perído prolongado, os animais tornaram-se susceptiveis à infeç̧ăo por Rotavífus. Os animais que receberam as menores quantidades de colostro imune adicional $(0,1 \%$ da dieta) ou aqueles que receberam grandes quantidades de colostro comum adicional (50\% da dieta), iniciaram a diarréia 1 dia apos o fim da dieta con colostro adicional. Neste trabalho, as bezerros que tiveram o meltor desempento em relação à diarréia foram aqueles que receberam quantidades intermediarias (1\% da dieta) de colostro proveniente de vacas vacinadas pre-parto, 
via intra-muscular e intra-mamária, o que proporcionou os mais altos niveis de anticorpos especf ficos contra Rotavirus, tanto no colostro, como, tambem, no sangue dos bezerros que receberam tal dieta. Esses anticorpos devem ter sido transferidos do soro sanguíneo para o intestino, assim provendo uma proteça passiva transitoria após o termino da alimentação com colostro por período prolongado, pois nestes animais o inćcio da diarréia se deu 3 a 9 dias após a cessação da dieta suplementar.

Esse mecanismo de transporte de Ig Gi serica para o intestino em bovinos ja foi verificado, tambem, por NEWBY \& BOURNE (1976b) e, mais recentemente, por BESSER et al. (1987) e BESSER et al. (1988a) e, como já discutido anteriormente, niveis elevados de anticorpos séricos no recem-nascido, protegem-no contra diarreia.

Uma outra alternativa para o atraso no inicio da diarréia, pode ser a de que os Ig Gi especificos contra Rotavirus presentes no colostro se ligaram seletivamente aos enterocitos e bloquearam de modo efetivo a infecça, similarmente descrito para Ig A em ratos por NAGURA et al . (1978).

0 fornecimento suplementar de colostro imune apresentou bons resultados quanto a diminuiçăo dos danos causados por diarréia, alem. do que, SAIf et al. (1983), também demonstraram que a alimentaçăo com colostro não imune adicional por 7 dias, proveniente de vacas não vacinadas, exerceu uma proteção parcial nos animais jovens, o que está 
de acordo com os resultadas abtidos por MACHADO NETO et al. (1989). SAIF et al. (1983), verificaram que bezerros alimentados com as maiores proporç̋es de colostro comum (10\% e 50\% na dieta líquida diária), tiveram un quadro de diarréia menos grave do que aqueles que obtiveram menores quantidades suplementares de colostro.

Com relaçăo ao fornecimento suplementar ou não, de colostro comum, o primeiro aspecto parece ser mais interessante, já que provoca um atraso no início da doença, uma menor duração do período de excreção de virus nas fezes e da própria diarréa (SAIF et al., 1983).

Desta forma, fica evidente que mesmo niveis baixos de anticarpos colostrais, contra Rotavirus e outras patógenos especl ficos, podem conferir uma proteção passiva parcial contra infecçôes causadas por estes agentes (WELLS \& SNODGRASS, 1978; SAIF \& SMITH, 1985; BELLINZONI et a ., 1989; MACHADO NETO et al., 1989). 
3. MATERIAL e METODOS

3.1. Local

A fase experimental de campo deste trabalho foi realizada na Fazenda Agrindus S.A. - Sta Rita, municipio de Descalvado, Estado de São Paulo, com área de 2930 hectares, situada a 850 metros de altitude, entre agosto de 91 e janeiro de 92 . Localiza-se a $21^{\circ} 58^{\circ}$ de latitude sul e $47^{\circ} 42^{\circ}$ de longitude oeste de "Greenwich". A precipitaçăo módia anual $\Leftarrow$ de $1500 \mathrm{~mm} e$ o clima é do tipo tropical de altitude.

A fazenda conta com um rebanto de gado Holandês P.C. de 1.100 cabeças, com 400 vacas em lactação; sendo a produção diária de leite $B$ em torno de 13.000 litros, com média de 28 litros de leite/vaca/dia.

Os animais são mantidos em regime de semi-confinamento em vários piquetes setorizadas pela propriedade.

As analises laboratoriais foram realizadas no Laboratório de Anatomia e Fisiologia Animal do Departamento de Zoologia da Escola Superior de Agricultura "Luiz de Queiroz" - USP - Piracicaba. 


\subsection{Animais}

Os animais que participaram deste experimento foram bezerros da raça Holandesa, recém-nascidos, fémeas, que após mamarem o colostro via mamadeira, eram trazidos ao bezerreiro com 1 a 2 dias de vida e mantidos em baias individuais até 90 dias de idade, com o término da desmama gradual.

A medida que as bezerras iam nascendo, eram alocadas a cada tratamento por ordem sorteada previamente, até completar 8 animais por tratamento.

0 experimento nå interferiu no manejo sanitário do rebanho, havendo semanalmente inspeção veterináia de todos os animais e tratamento daqueles com pneumonia, tristeza e diarreia. Os bezerros acometidos por diarréia eram tratados com uma soluçăo dilúda de sais para hidratação oral e, substituição de parte do leite da dieta por água, e iogurte. Nos casos mais graves fornecia-se antibioticos e/ou soro endovenoso, conforme o manejo estipulado pela fazenda.

Durante o perfodo em que as bezerras foram acompanhadas, (60 dias), elas passaram por vermifugaçäes orais (ao nascer e mensalmente), descorna e vacinação contra carbúculo, normalmente efetuada aos 2 meses de idade.

As mães das bezerras receberam as seguintes vacinas: 
- vacas: 60 dias antes do parto: E. coli; 40 e 20 dias antes do parto: E. coli e paratifo

- novilhas: 60 dias antes do parto: carbúnculo (dose inicial) e clostridium (mastite); 40 e 20 dias antes do parto: $E . \quad c 0 l i$ e paratifo.

3.3. Tratamentos

Através de sorteio foi determinada a ordem dos tratamentos aos quais cada bezerro, após o nascimento, era alocado. A ordem dos tratamentos ficou assim determinada:

Tratamento $1\left(T_{1}\right)=$ controle: fornecimento de colostro materno até o primeiro dia de vida lidem aos tratamentos $T_{2}$ e $\left.T_{3}\right)$ e, a partir dai, apenas leite até a desmama gradual aos 90 dias. Os bezerros tomaram 2 litros de leite pela manhã e 2 litros de leite à tarde.

Tratamento $2\left(T_{2}\right)=$ fornecimento de $30 \%$ da dieta liquida diária (4 1.) em colostro (pool), até 30 dias de idade, sendo que o colostro misturado ao leite foi fornecido 1 vez ao dia. Cada bezerro recebeu 0,8 litro de leite + 1,2 litros de colostro pela manha e 2 litros de leite à tarde.

Tratamento $3\left(T_{3}\right)=$ fornecimento de $30 \%$ da dieta liquida diária (4 1.) em colostro (pool), sendo tal quantidade de colostro dividida em 2 vezes ao dia, tambem por 
30 dias. Cada bezerro recebeu 1,4 litros de leite + 0,6 litro de colostro pela manhã e igual quantidade à tarde.

Em cada tratamento usou-se $\theta$ animais, totalizando 24 unidades experimentais. Duas unidades experimentais do $T_{1}$ morreram antes do final do experimento: animal 3, aos 35 dias de idade, foi sacrificado por romper 1 igamento da perna e animal 4, aos 45 dias de idade, por um quadro agravado de anemia e pneumonia.

Q leite fornecido em todos os tratamentos, antes e apos 30 dias de idade, era leite comum, proveniente das ordentas díarias das vacas e novilhas em lactação da fazenda.

o primeiro colostro fornecido aos bezerros foi proveniente da primeira ordenha pós-parto de suas respectivas mães. Houve um perfeito monitoramento dos bezerros recémnascidos por parte dos funcionários da fazenda, que forneciam o colostro (2 1.) aos mesmos, em mamadeiras, assim que nasciam. Apss os 30 dias de fornecimento de colostro suplementar, os animais do $T_{2}$ e T3 passaram a receber apenas leite comum ate - final da desmama gradual, aos 90 dias de idade. Alén da dieta If quida; leite ou leite + colostro, os bezerros tambem tinham à disposição: água, desde a sua chegada ao bezerreiro, ração inicial batida na própria fazenda $(1,5 \mathrm{~kg}$ por animal/ dia, desde o oitavo dia de vida) e feno. A cama das baias era trocada diariamente e a limpeza do piso de areia feita duas vezes ap dia. 
3.4. Colostro

Antecipadamente ao infcio do experimento, foi iniciada a coleta de colostro para o armazenamento dos "pools" de colostro. Foram utilizados colostros de primeira e segunda ordentas de várias vacas e novilhas que pariram no periodo pré-experimental e durante o experimento. Esses colostros eram homogeneizados em uma máquina misturadora e, em seguida, a concentração de imunoglobulina foi estimada atraves da densidade obtida com a emprego de um hidrômetro especifico. As temperaturas dos colostros foram registradas durante o procedimento para ajustes na concentração final de imunoglobulinas de acordo com a equaçăo que segue, desenvolvida por MECHOR et al. (1991):

$\begin{aligned} & \text { Concentraçăo final } \\ & \text { corrigida para } \\ & \text { leitura a } 20^{\circ} \mathrm{C}\end{aligned}=\left(\begin{array}{c}\text { concentraçăo } \\ \text { não } \\ \text { corrigida }\end{array}\right)-13,2+\left(\begin{array}{c}0,8 \cdot \text { temperatura } \\ (\mathrm{C})\end{array}\right)$

A técnica de utilização de un colostrómetro idealizado por FLEENOR \& STOTT (1980), consiste em um hidrometro modificado que relaciona a gravidade especf fica do colostro de vacas holandesas com a concentração de imunoglobulinas do mesmo. Estes autores, alén de Le BLANC et al. (1986 e 1992), os quais trabalharam com colostro de éguas, observaram altas correlaç̧es (de 0,70 até 0,99), entre 
concentração de imunoglabulinas do colostro e a gravidade especifica do mesmo, medida com colostrómotro, além da alta correlação de ambos parâmetros com Ig G sérico em potros.

$$
\text { Nas Tabelas } 6 \text { e } 7 \text {, ilustradas na Figura } 1 \text {, }
$$

encontram-se as concentraçaes finais de imunoglobulinas de cada "pool" e, as quantidades modias (em gramas) de imunoglobulinas fornecidas diariamente aos animais pelo colostro adicional em cada tratamento.

As quantidades diárias de imunoglobulinas fornecidas suplementarmente aos bezerros nos tratamentos 2 e 3 variaram de 12,924 a 136,320 g/dia, com uma media geral de $77,7 \theta$ g/dia. 
Tabela 6. Densidade específica e concentraçăo final (mg/ml) de imunoglobulinas dos 33 "pools" coletados para o experimento.

Pool

de colostro
Densidade

ConcentraçÃo

final $(\mathrm{mg} / \mathrm{ml})$
1

2

3

4

5

6

7

8

9

10

11

12

13

14

15

16

17

18

19
1,060

1,047

1,043

1,055

1,060

1,028

1,042

1,030

1,050

1,056

1,060

1,057

1,067

1,067

1,058

1,049

1,046

1,050

1,053
85,48

52,36

47,38

81,94

94,68

10,77

43,23

15,21

60,01

80,09

$89, \mathbf{8 B}$

81,84

100,51

102,11

71,18

61,86

48,62

62,01

64,85 
Tabela 6. Densidade específica e concentração final (mg/ml) de imunoglobulinas dos 33 "pools" coletados para o experimento (continuação).

Pool

de colostro
Densidade

1,062

1,052

1,059

1,059

1,065

1,069

1,061

1,066

1,055

1,061

1,043

1,051

1,056

$F^{a}$

$\mathbf{B}$

C

D

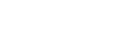

Concentraç̃̃o

final (mg/ml)

calumBY

90,17

67,90

88,13

83,33

104,21

113,60

90,82

105,16

75,54

78,82

52,98

63,75

77,29

73,30

a Năo foi medida a densidade, usou-se a média das concentraçōes finais. 
Tabela 7. Quantidades medias de Ig (gramas), fornecidas ans animais diariamente pelos "pools" de colostra.

\begin{tabular}{|c|c|c|c|c|}
\hline \multirow[b]{2}{*}{$\begin{array}{l}\text { Idade } \\
\text { (dias) }\end{array}$} & \multicolumn{4}{|c|}{ Tratamentos } \\
\hline & Media & $\begin{array}{c}\text { D. padrão } \\
( \pm)\end{array}$ & Média & $\begin{array}{c}\text { D. padrÃo } \\
( \pm)\end{array}$ \\
\hline 2 & 67,97 & 37,37 & 63,18 & 42,17 \\
\hline 3 & 72,95 & 36,05 & 77,29 & 29,35 \\
\hline 4 & 77,45 & 37,64 & 76,64 & 30,34 \\
\hline $\mathbf{5}$ & 75,77 & 40,00 & 71,48 & 28,47 \\
\hline 6 & 79,14 & 42,20 & 72,95 & 28,42 \\
\hline 7 & 89,06 & 26,24 & 74,44 & 22,04 \\
\hline 8 & 87,15 & 21,97 & 73,09 & 24,33 \\
\hline 9 & 87,49 & 23,25 & 84,04 & $25,6 \theta$ \\
\hline 10 & 87,59 & 26,79 & 89,69 & 30,05 \\
\hline 11 & 74,23 & 45,95 & 77,33 & 30,52 \\
\hline 12 & 84,06 & 36,59 & 81,61 & 34,03 \\
\hline 13 & 84,01 & 36,90 & 76,39 & 34,12 \\
\hline 14 & 77,68 & 40,66 & 66,99 & 35,23 \\
\hline 15 & 83,49 & 34,08 & 79,79 & 32,53 \\
\hline 16 & 81,21 & 30,06 & 68,39 & 32,71 \\
\hline 17 & 75,41 & 43,85 & $\mathrm{g3}, 26$ & 29,88 \\
\hline 18 & 90,21 & $22,8 \mathrm{~B}$ & 75,52 & 29,07 \\
\hline 19 & 90,54 & 16,92 & 79,77 & 14,44 \\
\hline 20 & 70,05 & 40,78 & 75,83 & 21,90 \\
\hline 21 & 80,95 & 31,17 & 64,32 & 25,12 \\
\hline 22 & 81,61 & 34,52 & 77,03 & 24,34 \\
\hline 23 & 78,94 & 35,24 & 73,48 & 32,00 \\
\hline 24 & 91,60 & 21,84 & 76,21 & 41,55 \\
\hline 25 & $8 \mathrm{~B}, 40$ & 24,72 & 82,83 & 32,68 \\
\hline 26 & $\mathrm{B7}, 20$ & 23,96 & 83,89 & 22,78 \\
\hline 27 & 92,05 & 28,61 & 84,42 & 22,80 \\
\hline 28 & 88,33 & 26,25 & 80,66 & 21,96 \\
\hline 29 & 91,22 & 34,24 & 70,02 & 28,62 \\
\hline 30 & 85,04 & 33,66 & 77,01 & 27,46 \\
\hline
\end{tabular}




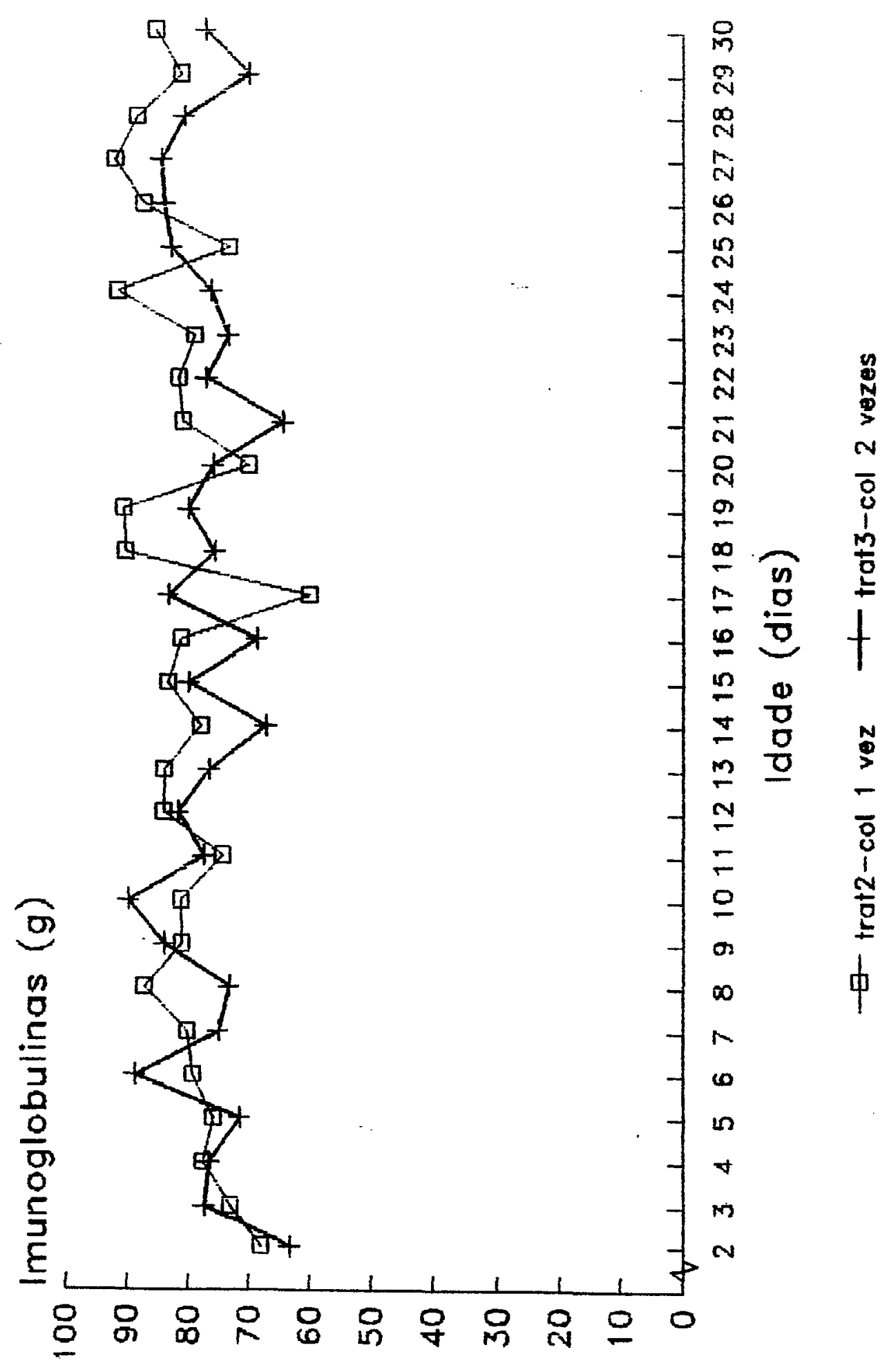

$\stackrel{\Xi}{\sigma}$

告

$n$
0
0

ชู

s

0
0
0
0
0
0
0
0
0
0
0

엉

(2)

站

bo

용

$\begin{array}{cc}n & 0 \\ 0 & 5 \\ -1 & 0 \\ -0 & 0 \\ 0 & 0 \\ 0 & 0 \\ 0 & 0\end{array}$

$\begin{array}{cc}0 & 0 \\ 0 & \\ 0 & E \\ 0 & 0 \\ 0 & 4 \\ -1 & 0 \\ D & 0 \\ 5 & 0 \\ 0 & 0 \\ 3 & 0 \\ 0 & 4\end{array}$

i

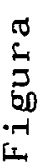


Cada "pool" de colostro, apos a identificaçăo devida; era congelado em freezer, primeiramente em sacos plasticos com o volume exato das refeiçôes diárias e posteriormente, por facilidade de manejo, em galoes plasticos de 3 e 5 litros de capacidade.

Os "pools" eram descongelados a medida que se tornava necessário seu uso para fornecimento aos animais. Em funça de picos de grande concentração de animais no experimento, ocorreram falhas em 15 refeiçBes. Para 0 tratamento 2 (colostro 1 vez ao dia), os animais $n^{0} 4$ no vigesimo terceiro dia; $n$ 으 6 no vigésimo e vigésimo segundo dias; $n^{\circ}$ a no decimo setimo dia $n^{\circ} 7$ no décimo primeiro dia, não receberam colostro, e apenas leite (4 litros por dia). Já no tratamento 3 (colostro 2 vezes ao dia), os animais $n^{\circ} 4$ no vigésimo nono dia, $n^{\circ} 5$ no vigésimo primeiro e vigésimo terceiro dias; $n$ ㅇ 6 no décimo sétimo e décimo nono dias; $n$ 으 7 no décimo sexto e décimo oitavo dias; $n$ 으 no setimo, oitavo e nono dias não receberam a porçăo de colostro fornecida pela manhã.

3.5. Amostragen de sangue

Foram coletadas amostras de sangue de cada bezerro, retiradas da veia jugular (aproximadamente $20 \mathrm{ml}$ ) e recebidas em tubo de centrifuga, sendo o sangue centrifugado e o soro resultante de cada amostra transferido para 2 
frascos devidamente identificados, mantidos a temperatura de - $20^{\circ} \mathrm{C}$ ate serem analisados. As amostras de sangue de cada animal foram retiradas nas sequintes idades de vida: 3 ; 5; $10 ; 15 ; 17 ; 20 ; 22 ; 25 ; 30 ; 40 ; 50$ e 60 dias.

3.6. Amostragem de fezes

Foram realizadas amostragens de fezes diariamente, no periodo de 3 dias até 30 dias de idade de cada animal. Tais amostras eram imediatamente classificadas con tabelas de campo para parámetros de consistencia, cor, presença de muco e de sangue nas fezes, de acordo com sistema empregado pelo AFRC (Agricultural and Food Research Council Inglaterra) (Tabelas 8 e 9). 
Tabela 8. Classificação da consistência fecal

Pontos

$\mathbf{0}$

1,0

2,0

3,0

4,0

Descrição das características

Fezes firmes e formadas

Fezes moles - perdem a forma sobre uma superficie plana

Fezes semi-1f quidas - fluem

lentamente de um recipiente

Fezes 11 quidas - fluem rapidamente

Fezes aquosas

Obs.: Meio ponto foi empregado quando necessário.

Tabela 9. Classificação da cor fecal

Pontos

$\mathbf{0}$

0,5

1,0

1,5

2,0

2,5

3,0

\section{Cores}

Marrom/marrom esverdeado

Amarelo/marrom

Verde

Cinza

Bege ou amarelo

Bege/creme ou amarelo/creme

Creme ou branco 
3.7. Comportamento e desempento

Diariamente foram analisados parâmetros de disposição, hidrataçăo e apetite dos animais, num período de 30 dias de idade, procurando-se relacionar estes dados com a ocorrencia de fezes anormais. Tamben foram registradas diariamente as temperaturas corporais, com intuito de verificar estado febril dos bezerros, associando-se a inapetencia e desidrataça.

Registrou-se o peso corporal dos animais no nascimento e nas seguintes datas: $5 ; 10 ; 15 ; 20 ; 25 ; 30$; 40 ; 50 e 60 dias de idade.

3.8. Análise das amostras

A fração Ig $G$ serica dos bezerros foi quantificada pelo metodo de imunodifusáo radial, técnica descrita por MANCINI et al. (1965), que se baseia na leitura do diâmetro formado pela reação do anticorpo da amostra con o anti Ig $G$ en meio de agar, comparando-se com diametros padröes pre-estabelecidos. Foram analisadas 288 amostras com repetição.

Para a construção das curvas padrão foi utilizada Ig G obtida da Sigma Chemical Company - USA. a agar foi preparado com concentraçăo de $1,2 \%$ de agarose em tampão TRIS - HCl $(\mathrm{pH}=8,0)$, com anti Ig $G$ obtido da Sigma Chemical Company - USA. Além da placa para curva padrão, todas as 
placas das amostras continham duas concentrações padröes, para avaliar variaçós entre placas. As amostras nas quais as repetições variaram acima de $5 \%$ foram refeitas novamente. Procedeu-se a leitura do diàmetro das reaçós apos 24 horas, à temperatura de $5^{\circ} \mathrm{C}$. Obteve-se as equaçớes, conforme as baterias de amostras iam sendo analisadas, seguindo-se o modelo abaixo:

$$
\begin{aligned}
& y=a x+b, \\
& \text { onde: } \\
& y=\text { concentração de Ig } G \text { serica em mg/ml; } \\
& x=\text { diâmetro da reação; obtendo-se a } \\
& \quad \text { coeficiente } r \text { de correlação medio de } \\
& \quad 0,9975 .
\end{aligned}
$$

A quantificação de protel na total sérica foi determinada pelo método de biureto, segundo REINHOLD (1953). Misturou-se $100 \mu l$ da amostra de soro com $4,9 \mathrm{ml}$ de $\mathrm{NaOH}$ $(0,75 \mathrm{~N})$ e $1 \mathrm{ml}$ de biureto reativo e agitando-se em VoRTEX. Após 20 minutos de reaçă, procedeu-se a leitura em espectrofotometro com comprimento de onda de $545 \mathrm{~nm}$ e atraves da curva padrão, pré-estabelecida com várias concentraçŏes de padrão de protel na, chegou-se às concentraçós de proteina serica em g/d1. Atraves da concentraçăo de proteina sérica de cada animal deduziu-se as quantidades de albumina, tomando-se por base os resultados das análises de soro em eletroforese, com a qual se obteve as porcentagens desta classe de proteina. 
Para separação da albumina usou-se a eletroforese em fitas de acetato de celulose. A diferenga de potencial empregada no sistema foi de 200 volts por 20 minutos e o tampão utilizado foi barbital sódico a 8,40 g/1, TRIS + glicina + pirofosfato.

Ao final do processo de separaçăo, as fitas foram imersas em corante Ponceau - 5 por 10 minutos, apss esse tempo lavadas en água e descoloridas em ácido acético $5 \%$ para procedimento da leitura das amostras en densitometro.

3.9. Delineamento experimental e anslise estatística

0 delineamento experimental foi inteiramente casualizado para parcelas sub-divididas, onde os tratamentos foram as parcelas e as idades experimentais as sub-parce1 as.

Procedeu-se as análises estatisticas usando-se o programa SAS Estatístico (6을 versão - USA - 1997), para tal delineamento, onde os parâmetros sericos foram submetidos à análise de variáncia e comparaçăo de médias quando necessário (Tukey's studentized), para tratamento, idades e interaçăo (tratamento $x$ idade). 
Para as variáveis peso e ganho de peso, foram feitas análises de variáncia e covariáncia e teste $t$ quando necessário, e, equaçbes de regressão para o periodo experimental, verificando interferencia da Imunoglobulina $G$ inicial.

Para as caracteristicas de diarréa foram usados os testes não parametricos de KRUSKAL - WALLIS, WILCOXON, $\mathrm{X}^{2}$, sendo feitos para cada data de coleta de fezes e naquelas onde a diferença foi significativa aplicou-se testes do Sistema de Análises para Estatistica não parametrica do CIAGRI-ESALQ.

Para proteina total, Ig G e albumina foram calculados os maiores e menores valores observados e idade de ocorrencia desses valores, fazendo-se análise de variáncia dos mesmos, assim como dos valores inicial, final e nas demais idades. Ande observou-se diferença significativa, aplicou-se o Teste Tukey.

Foram feitas algumas correlaçós (Pearson e Spearman) entre caracteristicas de fezes, parámetros sericos e de desempento.

Para determinar o comportamento das variáveis PT sérica, albumina e Ig G séricas foram traçadas regressöes e suas respectivas equaçós, lineares e não lineares. regressão não linear mostrou ser mais compativel com este tipo de variáveis. Seguiu-se o método da Secante ou falsa Posição (DuD = Don't use Derivate), onde o processo é intera- 
tivo para se chegar ao criterio de convergencia. As equaçás obtidas são do tipo exponencial (assintóticas), usando-se intervalos de confiança para assegurar a significácia das mesmas. Para testar a diferença entre as equaçóes nos tres tratamentos, usou-se o teste Ryan - Einot - Gabriel - Welsch Multiple Range Test. Todos esses pracedimentos pertencen ao SAS/STAT GUIDE FOR PERSONAL COMPUTERS, version 6 - SAS INST ITUTE - USA - 1987. 
4. RESUl tados E DISCUSSÃ

4.1. Proteina total (PT) serica

Na Tabela 10 estăo apresentadas as concentraçôes medias de PT sérica dos bezerros para cada tratamento. A Figura 2, ilustra a flutuação de PT sérica para os tratamentos no decorrer do perlodo experimental. Os dados originais 5ăo apresentados nos Apendices 1, 2 e 3.

No tratamento 1 (leite) os animais $n^{\circ}-3$ e 4 morreram antes de completarem 40 e 50 dias de idade, respectivamente.

A análise de variancia mostrou que houve diferença significativa para as concentraçßes de PT serica entre tratamentos $(p=0,0321) e$, também, entre as idades experimentais $(p=0,0001)$. Na houve, porém, interaçao tratamento $x$ idade, indicando um comportamento semelhante entre tratamentos nas várias determinaçôes. 
Tabela 10. Concentraçăo media de proteina total serica (g/ d1) nos tres tratamentos.

Idade

(dias)
1

Media

\section{Tratamentos}

2

Média
3

Media DP

\begin{tabular}{llll}
3 & $7,33 \pm 1,20$ & $7,82 \pm 1,24$ & $8,18 \pm 1,62$ \\
5 & $7,01 \pm 0,93$ & $7,73 \pm 1,27$ & $8,34 \pm 1,02$ \\
10 & $6,97 \pm 1,40$ & $7,30 \pm 1,30$ & $7,62 \pm 0,57$ \\
15 & $6,28 \pm 0,59$ & $6,98 \pm 0,88$ & $7,37 \pm 0,74$ \\
17 & $6,79 \pm 1,61$ & $6,84 \pm 0,84$ & $7,22 \pm 0,55$ \\
20 & $6,68 \pm 0,58$ & $7,06 \pm 0,54$ & $7,31 \pm 0,45$ \\
22 & $6,31 \pm 0,48$ & $7,10 \pm 0,77$ & $7,33 \pm 0,70$ \\
25 & $6,17 \pm 0,29$ & $6,91 \pm 0,82$ & $7,34 \pm 0,42$ \\
30 & $6,12 \pm 0,42$ & $6,69 \pm 0,80$ & $7,41 \pm 0,49$ \\
40 & $6,19 \pm 0,48$ & $6,89 \pm 0,93$ & $6,95 \pm 0,48$ \\
50 & $6,26 \pm 0,48$ & $6,81 \pm 0,76$ & $6,93 \pm 0,41$ \\
60 & $6,36 \pm 0,52$ & $7,35 \pm 0,84$ & $6,92 \pm 0,52$ \\
Midia & $6,54 \pm 0,38 *$ & $7,12 \pm 0,34$ & $7,41 \pm 0,43 *$ \\
\hline
\end{tabular}

TRAT 1 = Leite

TRAT $2=$ Colostro 1 vez ao dia

TRAT $3=$ Colostro 2 vezes ao dia

DP $=$ desvio padrão

* $\alpha=5 \%$ 


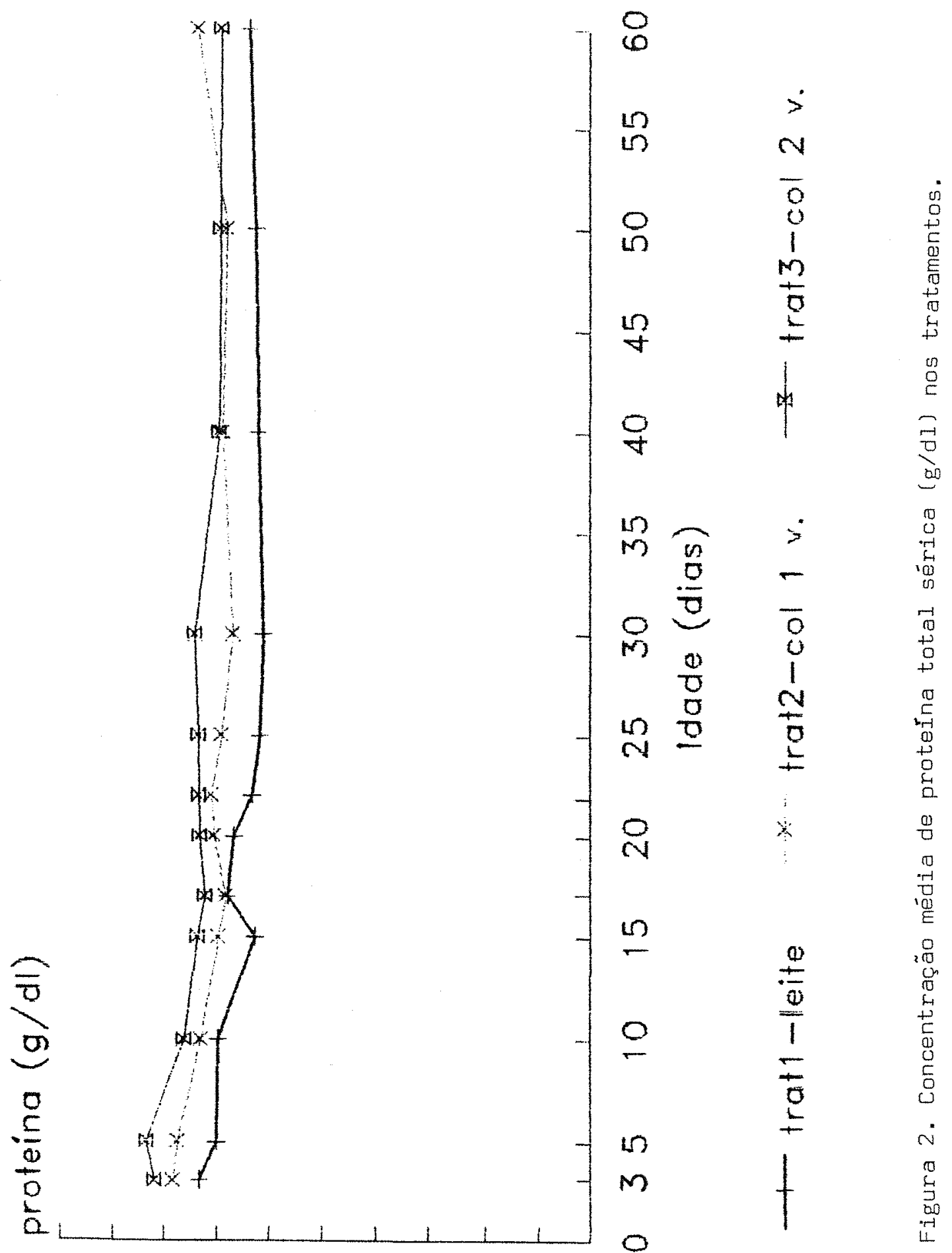


Atraves do teste Tukey verificou-se que a concentração media de PT sérica no perído experimental do tratamento 3, colostro 2 vezes ao dia $(7,41 \pm 0,43$ g/d1), foi superior estatisticamente a do tratamento 1 , 1eite 16,54 $\pm 0,38 \mathrm{~g} / \mathrm{dl})$. A módia de PT serica do tratamento 2 , colostro 1 vez ao dia, foi $7,12 \pm 0,34 \mathrm{~g} / d 1$. Estes valores medios, estão de acordo com aqueles encontrados por MACHADO NETO et a1. (1986).

o menor valor medio de PT sérica encontrado para o T1 foi $6,12 \pm 0,42$ g/d1; para o T2 foi $6,69 \pm 0,80$ g/d1 e para o T3 foi $6,92 \pm 0,52$ g/d1. As idades de ocorrencia para estes menores valores foram aos 30 dias, para o tratamento 1 e 2 e, 60 dias para o tratamento 3.

Bs valores máximos de PT sérica encontrados foram: $7,33 \pm 1,20$ para $T 1 ; 7,82 \pm 1,24$ para $T 2$, ambos aos 3 dias, e 8,34 $\pm 1,02$ g/d1 para $T 3$, aos 5 dias de idade.

Houve diferença significativa entre os valores finais encontrados para PT serica, sendo que aos 60 dias $T 2(7,35 \pm 0,84)$ foi superior ao $T 1(6,36 \pm 0,52)$. A concentração de PT sérica pode ser consequiencia das variaçăes na concentraçăo de imunoglobulinas adquiridas do colostro materno (BUSH et al., 1971; BusH et a1., 1973). A PT sérica também poderia ser influenciada pelas diferenças entre os tratamentos empregados, porém este efeito não pode ser detectado no inicio e sim ao longo do experimento. 
No caso do T3, que apresentou maior PT serica, as imunoglobulinas do colostro suplementar permaneceram continuamente no lúmen intestinal, havendo, supostamente, uma maior proteção local contra infeç̧ões entéricas, o que está de acordo com SNODGRASS et al. (1980); SAIF et al. (1983); SAIF \& SMITH (1985); TSUNEMITSU et al. (1989). Já no $T 1$, onde os animais receberam leite, provavelmente os desafios exercidos pelos patógenos no lúmen intestinal causaram uma maior pressão para que as imunoglobulinas sericas migrassem para a mucosa, onde não havia anticorpos adicionais exercendo proteção local. Este mecanismo de "migraçăo" foi observado por NEWBY \& BOURNE (1976b); PORTER (1979); BESSER et al. (1988a). Em conseqüencia deste fato pode ter havido uma redução das Igs séricas, determinando assim, queda na PT serica.

Para demonstrar o comportamento da PT sérica ao longo do período experimental, foram usadas regressóes não lineares, já que as lineares apresentaram baixos valores de $r^{2}(0,073)$.

As regressరัes não linerares foram obtidas atraves do metodo DUD (SAS/STAT Guide for Personal Computers Version 6-1987), um processo interativo, que permitiu obter uma equação exponencial média para os tres tratamentos, descrita a seguir: 
Proteina $=$ Bo . idade ${ }^{\text {Bi }}$, onde:

Proteina (PT) $=8,244$. idade $-0,0555$, onde $B_{1}$ negativo, indica a queda díaria ajustada no teor de PT (g/d1).

$0 R^{2}$ desta equação foi 0,98 , o Quadrado Médio do Resi duo (QMR) foi 0,819 e os Intervalos de Confiança para os coeficientes Bo e $B_{1}$, foram respectivamente: 7,827 a 8,660 e $-0,073$ a- -0,039, enfatizando a significancia do modelo. Tambem, foram traçadas regressðes não lineares, pelo mesmo médodo, individuais para cada tratamento, obtendo-se as seguintes equaçōes:

Tratamento 1 (1eite): Proteina (PT) = 7,882. idade $-0,0669$, onde $R^{2}=0,98 ;$ QMR $=0,687$ e Intervalos de Confiança (IC) para os coeficientes Bo $E$ Bi, foram respectivamente: 7,191 a 8,573 e $-0,097$ a $-0,037$.

Tratamento 2 (col* 1 vez ao dia): PT $=8,059$. idade $-0,0426$, onde $R^{2}=0,99 ;$ QMR $=0,8498$ e IC para Bo $e$ B1, foram respectivamente: 7,341 a 8,777 e $-0,072$ a $-0,013$.

Tratamento 3 (cal. 2 vezes ao dia): PT = 8,891 idade $-0,0630$, onde $R^{2}=0,99 ;$ QMR $=0,507$ e IC para Bo $\mathrm{E} \mathrm{B}_{1}$, foram respectivamente: 8,314 a 9,468 e $-0,085$ a $-0,041$. 
Procedeu-se ainda a comparação dos valores ajustados dos tratamentos pela analise de variancia e obteve-se uma diferença significativa entre as equaçóes de regressão ao nivel de $p=0,0001$. Aplicando-se o "Ryan-Eynot- Gabriel-Welsch Multiple Range Test" do SAS, verificou-se que a variável PT sérica nos tratamentos 2 e 3 foi superior ao 1 (leite). Embora não havendo interação entre tratamento x idade, as 3 equaçbes de regressăo são diferentes entre $5 i$ $(p=0,05)$, mostrando que no decorrer do perfodo experimental o tratamento 1 fai inferior aos outros dois e que em alguns periodos estas diferenças podem ter diminuido ou se acentuado, como pode ser visto na figura 2 . A queda de PT serica no tratamento 1 foi em média mais acentuada.

A análise de variáncia dos valores residuais mostrou que nå houve diferença significativa entre tratamentos, o que indica que a distribuiçăo dos dados nas curvas de cada tratamento e semelhante, permitindo a comparação das regressós pelo teste anterior.

Estas equaçóses de regressão indicam que ocorreu queda da concentração de PT serica, mostrando que houve um processo de catabolismo protéico, o que está de acordo com HUSBAND et al. (1972); PORTER (1972); FAGLIARI et a1. (1983) e MACHADO NETO et al. (1986). Essa queda observada é consequiencia, provavelmente, da redução de anticorpos adquiridos passivamente do colostro, pois as imunoglobulinas perfazem 20 a $40 \%$ do total de proteinas sericas. 
Na Figura 2, observa-se um pequeno aumento da concentração de PT serica no tratamento 2 , apos 50 dias de idade, o que não foi detectado pela equação de regressăo, que ajusta os valores observados. Provavelmente, a taxa de anabolismo protéco, principalmente de imunoglobulinas (HusBAND et al., 1972), năo sobrepuja a taxa de catabolismo, devido ao nivel elevado de imunoglobulinas adquiridas passivamente pelo colostro, o que sera discutido com mais detalhe no iten "Ig $G$ serica".

Assim, refletida pela flutuação no nivel de anticorpos sericos, a concentraçăo de proteina total serica varia de forma semelhante a flutuação de imunoglobulinas séricas a partir do nascimento dos bezerros (TENNANT et al." 1969). A concentraçăo mais baixa se verifica ao nascer, antes da ingestão do primeiro colostro; a mais alta ocorre por volta dos 4 a 5 primeiros dias de vida, logo apos o que se observa un decréscimo gradual, até se estabilizar (TENNANT et a1., 1969; FAGLIARI et a1., 1983; NOCEK et al., 1984). Neste trabalno, as equaçßes de regressão mostram o comportamento decrescente da proterna total serica, sendo que apss o mesmo deve haver a fase de estabilização, a qual reflete a produção de anticorpos pelo próprio bezerro, quando seu sistema imune torna-se lentamente ativo, coincicindo com o periodo de decilnio ou catabolismo dos anticorpos absorvidos passivamente. Esta fase e referida à sintese endógena, que segundo HUSBAND et a 1. (1972), se inicia entre 
8 a 16 dias após o nascimento, para Ig $G$ e Ig M, enquanto que para Ig A se inicia apenas aos 64 dias de vida.

\subsubsection{Albumina}

Os niveis medios de albumina serica, nas diferentes idades, estão apresentados na Tabela 11, e a Figura 3 ilustra a flutuaçăo desta variável na fase experimental. Os dados originais são apresentados no Apendices 4, $5 e 6$.

A análise de variância mostrou que houve diferença significativa para as concentraçōes de albumina sérica entre tratamentos $(p=0,0298)$, porén năo houve diferença significativa para a variável, entre as idades experimentais (p $=0,0936)$; tamben não existindo interação Tratamento $x$ idade $(p=0,1350)$. Estes resultados indicam que houve um comportamento homogéneo no decorrer do experimento. Atraves do teste Tukey, verificou-se que a concentraçăo media geral de albumina sérica do tratamento 2 (col. 1 vez ao dia) superou estatisticamente a do tratamento 1 (leite) e năo diferiu do tratamento 3 . As medias dos tratamentos foram: $T_{1}=3,07 \pm 0,14 \mathrm{~g} / \mathrm{dl} ; \mathrm{T} 2=3,33 \pm 0,15 \mathrm{~g} / \mathrm{dl}$ e $\mathrm{T3}=3,22 \pm 0,31 \mathrm{~g} / \mathrm{dl}$. 
Tabela 11. Concentração media de albumina sérica (g/dl) nos três tratamentos.

Idade

(dias)
1

Media DP
Tratamentos

2

Media DP
3

Media DP

\begin{tabular}{llll}
3 & $2,96 \pm 0,35$ & $3,28 \pm 0,66$ & $3,01 \pm 0,25$ \\
5 & $2,87 \pm 0,45$ & $3,02 \pm 0,52$ & $3,05 \pm 0,72$ \\
10 & $3,12 \pm 0,55$ & $3,21 \pm 0,89$ & $3,07 \pm 0,46$ \\
15 & $3,16 \pm 0,65$ & $3,38 \pm 0,53$ & $2,91 \pm 0,45$ \\
17 & $3,13 \pm 0,45$ & $3,56 \pm 0,90$ & $2,89 \pm 0,38$ \\
20 & $3,38 \pm 0,17$ & $3,37 \pm 0,71$ & $3,13 \pm 0,58$ \\
22 & $3,15 \pm 0,33$ & $3,24 \pm 0,42$ & $3,01 \pm 0,54$ \\
25 & $3,14 \pm 0,52$ & $3,44 \pm 0,39$ & $3,47 \pm 0,26$ \\
30 & $2,90 \pm 0,39$ & $3,45 \pm 0,67$ & $3,92 \pm 0,63$ \\
40 & $2,95 \pm 0,63$ & $3,57 \pm 0,67$ & $3,75 \pm 0,62$ \\
50 & $3,11 \pm 0,72$ & $3,31 \pm 0,37$ & $3,22 \pm 0,36$ \\
60 & $2,93 \pm 0,16$ & $3,19 \pm 0,39$ & $3,19 \pm 0,69$ \\
Mia & $3,07 \pm 0,14 *$ & $3,33 \pm 0,15 *$ & $3,22 \pm 0,31$ \\
\hline
\end{tabular}

TRAT $1=$ Leite

TRAT 2 = Colostro 1 vez ao dia

TRAT $3=$ Colostro 2 vezes ao dia

DP = desvio padrão

* $\alpha=5 \%$ 


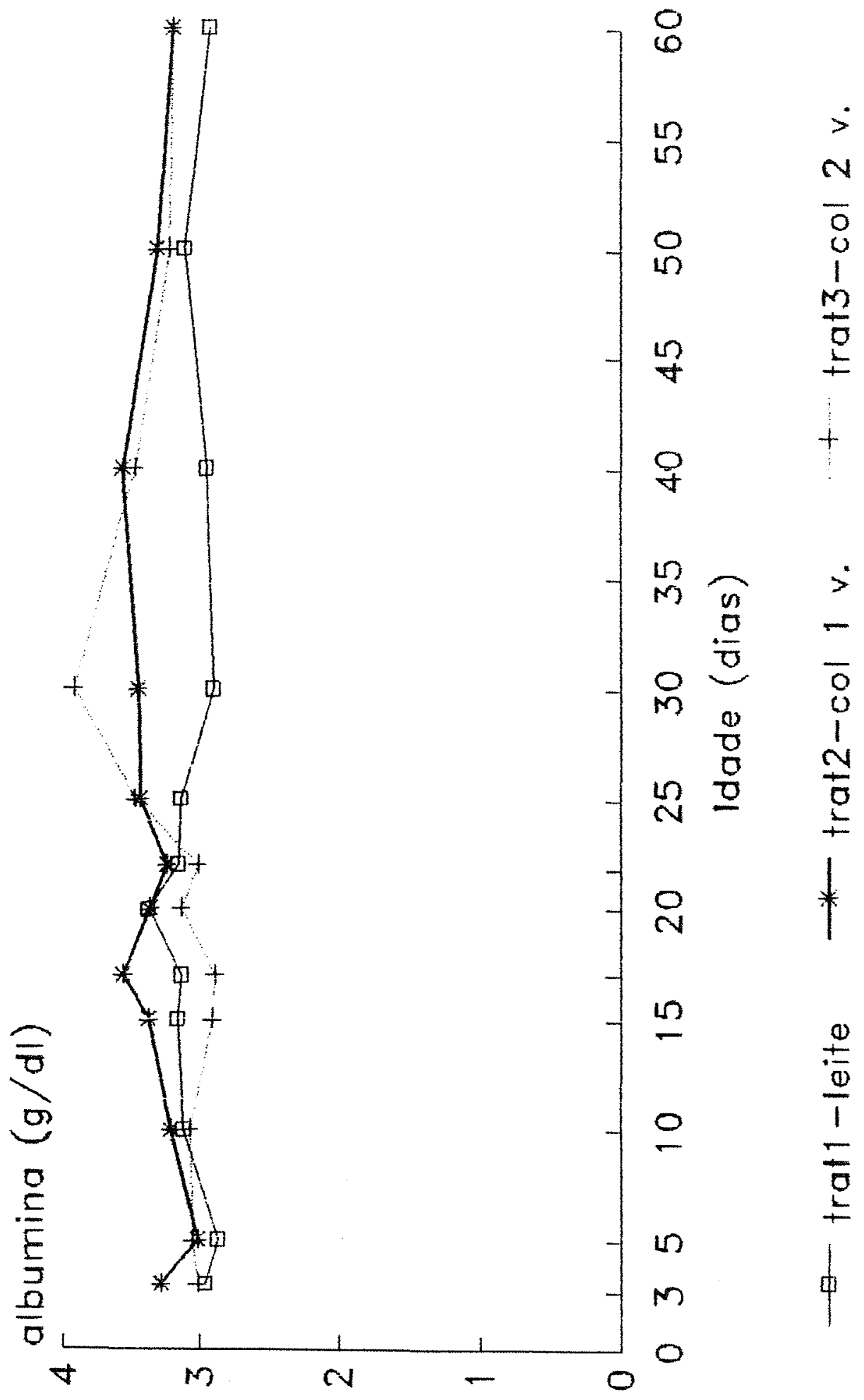

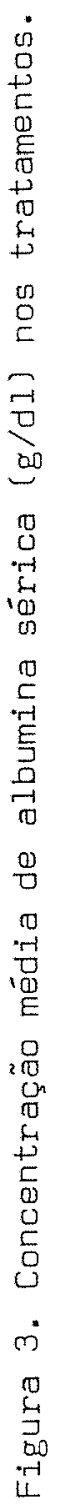


Năo houve diferença significativa para as medias de albumina entre tratamentos na data inicial, 3 dias e final, 60 dias.

A albumina representa a maior fraçao de proteina total serica e e a principal responsável pela manutenção da pressão osmótica no soro sangíl neo, podendo a sua concentração variar em conseqưencia da flutuação de outras classes de proteinas sericas (GUYTON, 1978).

No caso do tratamento 1 (1eite), o fato de ter apresentado o menor valor de albumina serica pode ter influenciado para que o mesmo apresentasse, tamben, o menor valor de PT sérica. Pois, o tratamento 2 (colostro 1 vez ao dia) (Figura 2), mesmo com niveis mais baixos de Ig G, 0 que serk discutido adiante, apresentou nIveis maiores de PT serica, possivelmente um reflexo da maior concentraçăo de albumina sérica, também apresentada por este tratamento.

No tratamento 3 (colostro 2 vez ao dia) provavelmente o nivel mais alto de PT, refletido supostamente por niveis mais altos de $19 G$ no infcio do perfodo, compensado pelos niveis de albumina, que tenderam a aumentar aos 20 dias, compensando o catabolismo mais intenso de anticorpos neste tratamento, mantendo a estabilidade na concentração da PT serica.

A variação nos níveis de albumina serica provavelmente tenta compensar mudanças na concentração de 
outros solutos séricos e da própria variaçăo do nivel de fluídos do sangue, mantendo a pressão osmótica (P.Q.) do mesmo, constante. Apesar de não ter havido diferença significativa na albumina no decorrer do periodo experimental, possi veis quedas em sua concentração podem ser atribui das ao seu efeito compensatório, tentando manter a P.o. dos fluídos corporais que aumenta quando há perdas intensas de liquidos, - que é observado em diarréias severas, por exemplo.

- comportamento da albumina serica foi verificado, ao longo do período experimental, por equaçzes de regressao semel hantes às usadas para PT serica. Tambem neste caso, as regressbes não 1 ineares expressaram de mel hor maneira o comportamento da variável.

Pelo metodo Dud de regressão não linear, obteve-se a equação exponencial media, que descreveu o comportamento da albumina como levemente crescente ao longo do periodo:

$$
\begin{aligned}
& \text { Albumina }=2,945 \text {. idade }+0,0294(g / d 1) \\
& B o=2,945 \text { e } B_{1}=0,0294
\end{aligned}
$$

A equação apresentou $R^{2}=0,97$, Quadrado Medio do Residuo $=0,309$ e os Intervalos de Confiança para Bo $e B_{1}$, foram respectivamente 2,725 a 3,165 e 0,00498 a 0,0538 . 
As equaçbes de regressão não lineares individuais para o tratamento 1 (leite) e tratamento 2 (colostro 1 vez ao dia) năo foram significativas.

No tratamento 3 (colostro 2 vezes ao dia), a equação individual foi significativa: Albumina $=2,737$ idade $+0,0554$, onde $R^{2}=0,77 ; \mathrm{QM}$ residuo $=0,327$ e I.C. para Bo $=2,367$ a 3,107 e para $\mathbf{B}_{1}=0,0119$ a 0,0989 , sendo que o coeficiente Bi mostra que realmente este tratamento teve um comportamento crescente significativo para albumina sérica ao longo do períado.

\subsection{Imunoglobulina sérica (Ig G)}

Os niveis medios de imunoglobulina serica, nas diferentes idades, săo apresentados por tratamentos na Tabela 12 e a flutuação desta variável na fase experimental é mostrada na figura 4 . Os dados originais de Ig G serica são apresentados nos Apêndices 7,8 e 9.

A análise de variancia mostrou que houve diferença significativa na concentração serica média de Ig G entre idades $(p=0,0001)$, e semelhança, existindo pequena tendéncia a diferir, entre tratamentos $(p=0,1171)$. Este fato provavelmente se deu em função da existência de interaçăo significativa entre Tratamento $x$ idade $(p=$ 
0,0022), o que levou a se fazer a análise de variáncia em todas as idades experimentais.

Os valores de Ig $G$ serica foram significativamente diferentes entre tratamentos em duas idades: 15 dias $(p=0,0287)$ e 17 dias $(p=0,0175)$

Atraves do teste Tukey $(p=0,05)$, verificouse que nestas datas o tratamento 3 (colostro 2 vezes) superou o tratamento 2 (colostro 1 vez).

As médias de Ig G serica aos 15 dias foram $36,65 \pm 8,06$ para T3 e 24,43 $\pm 9,87$ para T2 e, aos 17 dias foram $37,66 \pm 9,76$, no $T 3$ e $24,38 \pm 9,39 \mathrm{mg} / \mathrm{ml}$, no $T 2$.

Os valores médios de Ig 6 serica por tratamento foram: $28,99 \pm 4,5$ para tratamento $1 ; 26,01 \pm 3,2$ para tratamento 2 e $33,98 \pm 6,6 \mathrm{mg} / \mathrm{ml}$ para tratamento 3.

Os valores medios de Ig G serica (mg/ml) não diferiram significativamente $(p=0,214)$ na data inicial sendo $38,74 \pm 11,05$ para tratamento $1 ; 33,16 \pm 12,47$ para tratamento 2 e $44,43 \pm 13,46 \mathrm{mg} / \mathrm{ml}$ para tratamento $3 e_{*}$ estão de acordo com EDWARDS et al. (1982). 
Tabela 12. Concentração modia de Ig G serica (mg/ml) nos tres tratamentos.

Idade

(dias)
1

Média DP
Tratamentos

2

Media DP
3

Media DP

\begin{tabular}{|c|c|c|c|c|c|c|c|c|}
\hline 3 & 38,74 & \pm & 11,05 & $33,16 \pm 1$ & 12,47 & 44,43 & \pm & 13,46 \\
\hline 5 & 36,42 & \pm & 10,93 & $31,18 \pm 1$ & 11,46 & 44,65 & \pm & 10,62 \\
\hline 10 & 33,50 & \pm & 12,24 & $29,20 \pm$ & 11,65 & 41,13 & \pm & 9,35 \\
\hline 15 & 27,41 & \pm & 8,25 & $24,43 \pm$ & $9,87 *$ & 36,65 & \pm & $B, 06 \%$ \\
\hline 17 & 28,18 & \pm & 6,65 & $24,38 \pm$ & $9,39 \%$ & 37,66 & \pm & $9,76 *$ \\
\hline 20 & 29,00 & \pm & 8,69 & $23,76 \pm$ & $\theta, 30$ & 32,73 & \pm & 8,34 \\
\hline 22 & 27,03 & \pm & 8,77 & $24,06 \pm$ & 10,54 & 31,75 & \pm & 8,34 \\
\hline 25 & 25,67 & \pm & 7,57 & $23, \mathrm{B3} \pm$ & 9,03 & 30,71 & \pm & 7,83 \\
\hline 30 & 27,00 & \pm & 7,73 & $24,81 \pm$ & 6,55 & 28,66 & \pm & 5,64 \\
\hline 40 & 24,15 & \pm & 6,75 & $24,58 \pm$ & 5,10 & 29,53 & \pm & 7,49 \\
\hline 50 & 26,04 & \pm & 5,19 & $22,67 \pm$ & 5,82 & 26,00 & \pm & 6,35 \\
\hline 60 & 24,69 & \pm & 3,39 & $25,99 \pm$ & 5,14 & 23,93 & \pm & 4,45 \\
\hline Media & 28,89 & \pm & 4,50 & $26,01 \pm$ & 3,20 & 33,98 & \pm & $6,60 n$ \\
\hline
\end{tabular}

TRAT 1 = Leite

TRAT 2 = Colostro 1 vez ao dia

TRAT $3=$ Colostro 2 vezes ao dia

DP = desvio padrãa

$* \alpha=5 \%$

ns = năo significativo 


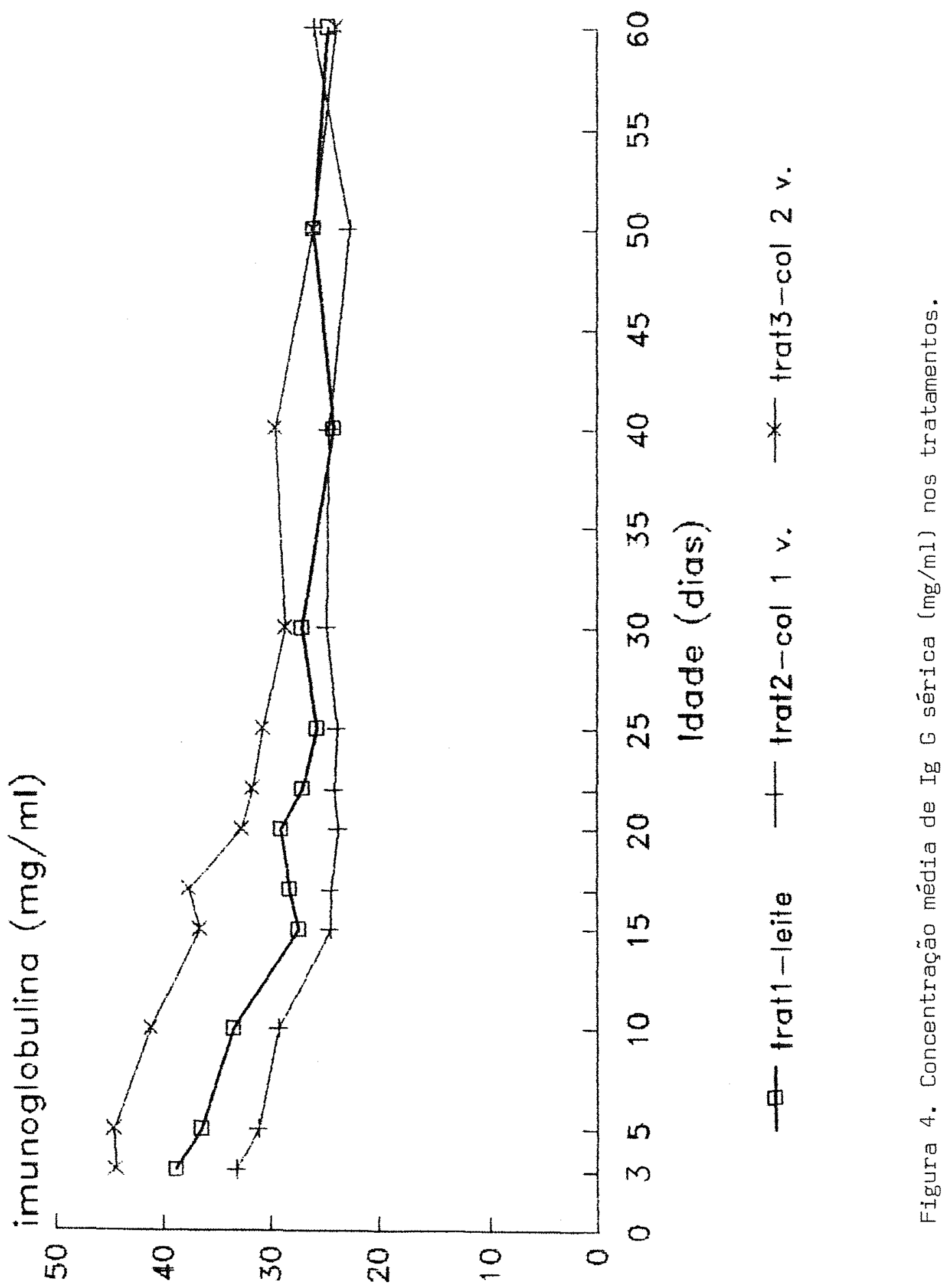


Geralmente, diferenças significativas entre Ig $G$ serica no decorrer do perfodo revelam uma absorção diferenciada de Igs do colostro nos primeiros dias de vida, o que provavelmente ocorreu neste experimento, mas não foi detectado pela análise estatistica. A variaçăo no nivel de anticorpos absorvidos do colostro entre animais pode ser muito grande, devido a varios fatores inerentes ao proprio colostro, ao bezerro e/ou manejo (EDWARDS et al., 1982; DONOVAN et al., 1986; ROBISON et al., 1988).

A diferença significativa existente para Ig G apenas no periodo de 15 a 17 dias pode estar relacionada com a melhor distribuiçăo de anticorpos no intestino, obtida com o parcelamento do colostro suplementar em duas vezes ao dia realizada no tratamento 3 , o qual apresenta Ig 6 mais alta nestas idades. A presenga continua de Ig $G$ no lúmen intestinal pode ter dado maior proteção local aos animais do tratamento 3 contra patógenos causadores de diarréia (SNODGRASS \& WELLS, 1976; SAIF et a1., 1983; HAL, 1986; CASTRUCCI et al ., 1989; TSUNEMITSU et al , 1989).

Como foi demonstrado en ruminantes, pode ocorrer uma transudação, ou migraçăo, de anticorpos sericos provenientes do colostro para as secreços do organismo, como lagrima, saliva, trato respiratório e trato intestinal. Este mecanismo pode ocorrer na tentativa de aumentar a proteção local das mucosas contra microrganismos invasores: 
sendo mais intenso dos 10 ags 20 dias de idade e em animais que absorveram grandes quantidades de Ig do colostro (NEWBY \& BOURNE, 1976b; PORTER, 1979; BESSER et a1., 1987; BESSER et al., 1989a, BESSER et al.,1988b).

Desta maneira, se houver anticorpos locais suplementares, provavelmente não ocorrerá migraçăo intensa de Ig sérica para o lúmen. Porem, no T2,apesar do fornecimento de colostro suplementar, a distribuição de anticorpos no lúmen obtida com o fornecimento de colostro uma vez ao dia, pode não ter sido eficaz para exercer a proteção local (SAIf et al., 1983). Alem disto, pode ter ocorrido uma diarréia osmótica, desencadeada pela concentração maior de sólidos totais do colostro (FOLEY \& OTTERBY, 1988 e NOCEK et a1., 1984), que era fornecido apenas uma vez ao dia. Este fato poderia facilitar a multiplicaçao de patógenos, agravando a diarréia infecciosa (SAUNDERS \& WIGGINS, 1981 ; NOCEK et $a 1 ., 1984$; HALL, 1987; RUMESSEN, 1989; BANWELL, 1990).

Como será discutido adiante, no item 4.3 .2 , a diarréia mais severa no T2, poderia exigir uma proteção maior dos anticorpos sericos, que migrariam de forma mais intensa para o lúmen, já que aqueles adicionais poderiam ter sido perdidos na diarréia. Porém, parece mais lógico que esta migração ocorra em animais que não receben colostro e anticorpos adicionais no lúmen, e sim, apenas leite. 
Este mecanismo de migração pode determinar quedas na Ig serica, refletindo diminuiçăo na proteina total serica, ao longo do perfodo. BESSER et al. (1988b), concluiram que a maior parte da Ig Gi que aparece no lúmen intestinal de bezerros provém da transferencia das mesmas do sangue para o lúmen $e$, este mecanismo resulta em uma ligação antigeno-anticorpo no trato intestinal.

Neste trabalio, foram encontradas correlaçชes positivas entre PT sérica e Ig G serica no $3^{\circ}$ dia de idade: $r=0,819$ no $T 1, r=0,890$ no $T 2$ e $r=0,889$ no $T 3$. Estes valores estão de acordo com NoCEK et al. (1984), que verificaram $r=0,84$ entre PT $\mathrm{Ig} G$ séricas entre 12 horas a 4 dias de vida, valor que diminuiu com o tempo. Resultados semelhantes foram também encontradas por MACHADO NETO et al. (1986). Isto ocorre porque as imunoglobulinas séricas fazem parte da fração proteina total serica, refletindo sua concentração.

Os valores máximos de Igs sêricas são observados, geralmente, no primeiro dia de vida, em funçăo da absorçăo de anticorpos do colostro verificada nesta idade (McCOY et al., 1970; HUSBAND et al., 1972; RIBEIRO et al.; $1983)$.

Neste trabaliho não foram coletadas amostras de sangue no $1^{\circ}$ dia de vida. Desta maneira, os maiores valores medios de Ig G serica observados foram: $38,74 \pm$ 11,05 aos 3 dias para o tratamento $1,33,6 \pm 12,47$ a0s 3 
dias para o tratamento 2 e $44,65 \pm 10,62 \mathrm{mg} / \mathrm{ml}$ aos 5 dias para o tratamento 3.

Os menores valores medios de Ig G observados foram: $24,15 \pm 6,75$ aos 40 dias para o tratamento $1 ; 22,67 \pm$ 5,82 aos 50 dias para o tratamento 2 e $23,92 \pm 4,45 \mathrm{mg} / \mathrm{ml}$ aos 60 dias para o tratamento 3 . Os valores de I9 G observados na data final, 60 dias, não variaran entre si.

De acordo com trabalhos de EDWARDS et al. (1982) e ROBISON et al. (1988), os niveis de Ig G séricas observados neste experimento nos primeiros dias de vida estão acima dos niveis necessarios, refletindo o bom manejo da propriedade no monitoramento do bezerro nas primeiras 24 horas de vida.

Segundo LQGAN et al. (1974); RIBEIRO et al. (1983) E MACHADO NETO \&ACKER (1986), animais que apresentam altas concentraçôes de anticorpos sericos absorvidos do colostro podem retardar a produção endógena de imunoglobulinas, enquanto que aqueles com baixos teores de Ig serica inicial antecipariam essa produção.

Provavelmente, houve apenas tendencia em antecipar a produção endógena de anticorpos no tratamento 1 (leite), com a observaçăo do menor valor de Ig G serica aos 40 dias, o que pode ser conseqüencia da presença de menores quantidades de Ig local neste tratamento. Esta situação pode determinar um maior desafio para vencer os patogenos intes- 
tinais, o que determinaria uma atividade do sistema imune endógeno mais precoce (MACHADO NETO \& PACKER, 1986). Também no tratamento 2 , onde se observou diarreia mais severa, 0 desafio pode ter sido razoavelmente grande, apesar da existencia de anticorpos suplementares no lúmen, o que levaria a uma antecipação do anabolismo de anticorpos endogenos.

Os valores iniciais elevados de Ig $G$ sérica observados, prolongaram o período de declinio nas curvas de flutuação de Ig G nos tratamentos (Figura 4), não sendo observado aumento significativo na concentraçăo de Ig sérica, como ocorreu nos trabalhos realizados por RIBEIRo et a 1. (1983) E MACHADO NETO \& PACKER (1986) que tiveram concentraçoes iniciais de Ig $G$ mais baixas.

Foram testadas várias equaçóes de regressao para descrever o comportamento da variável Ig G serica, dentre elas, as que mostraram maior adequação foram as regressชอย não lineares. Estas regressðes foram obtidas atraves do método DUD, pertencente ao programa SAS Estatístico (1987), de forma semelhante as obtidas para as variáveis PT sérica e albumina sérica.

Devido à significáncia na existéncia de interação Tratamento $x$ idade, indicando comportamentos diferenciados da variável Ig G serica entre Tratamentos ao longo do perfodo experimental, foram traçadas três equaçós de regressão nă linear, do tipo exponencial, para cada trata- 
mento: Trat. 1 (1eite): Ig $G=47,42$. idade $-0,175$, onde $R^{2}$ $=0,93, \operatorname{QMR}=67,89$ e IC para Bo $(47,42)=39,08$ a 55,76 e para $B_{1}(-0,175)=-0,24$ a $-0,11$.

T2 (col. 1 vez ao dia): Ig $G=36,85$ idade $-0,122$, onde $R^{2}=0,90$, QMR $=77,10$ e IC para Bo $(36,85)$ $=28,93$ a 44,76 e para $B_{1}(-0,122)=-0,196$ a $-0,047$.

T3 (col. 2 vezes ao dia): Ig $G=59,66$. idade ${ }^{-0,198}$, onde $R^{2}=0,95$, QMR $=70,73$ e IC para Bo $(59,66)=50,97$ a 68,35 e para $B_{1}(-0,198)=-0,25$ a $-0,14$. Os niveis decrescentes de Ig G săo dados pelas equaçôes em mg/ml. Os $R^{2}$ e QMR apresentados são mais adequados do que aqueles das equaçres de regressăo 1 inear.

A seguir, foi feita a comparaça dos valores ajustados dos tratamentos, pela análise de variáncia, obtendo-se uma diferença significativa entre as equaçöes de regressão de cada Tratamento $(p=0,0001)$. Procedeu-se 0 teste para diferenças entre medias "Ryan - Einot - Gabriel Welsch Multiple Range Test" (SAS Estatistico), verificandose que as três equaç̧̋es, para cada un dos tratamentos, são diferentes entre si, onde o Tratamento 3 (colostro 2 vezes ao dia) mostra uma queda mais acentuada quanto ao teor de Ig G sérica ao longo do perfodo, além de um valor de Bo maior, indicando sua superioridade en relaçăo ao nivel de anticor- 
pos. A semelhança na distribuiçăo dos dados verificada em cada tratamento, para as curvas de regressão, permitiu a comparação entre equaçôes.

A flutuação de imunoglobulinas sericas é resultante da interação do catabolismo dos anticorpos adquiridos passivamente, da transudação de imunoglobulinas sericas absorvidas do colostro para o lúmen intestinal e do infcio da produçăo endógena, o que se acentua a partir do $20^{\circ}$ ao $30^{\circ}$ dia de idade (BuSH et a1., 1971; HUSBAND et a $\ldots$ 1972 E MACHADO NETO \& PACKER, 1986).

Em relação à queda mais acentuada e prolongada de Ig $G$ no tratamento 3 , este fato pode estar aliado à grande quantidade de Igs adquiridas passivamente que necessitam ser catabolizadas, desta forma mascarando o anabolismo endógeno de anticorpos, que é incipiente na fase inicial da vida (até 50 ao 60 dias de idade).

Apesar de não ter sido detectada diferença significativa entre tratamentos para a concentraçăo inicial de Ig G serica, a tendencia do tratamento 2 (colostro 1 vez) em apresentar menor concentraçăo inicial pode explicar a fato da sua curva de regressão mostrar o comportamento menos variável, com menor taxa de queda diária na concentração de Ig sérica. Neste tratamento, as quantidades menores de anticorpos passivos existentes a serem catabolizadas mostrariam que a produçăo endógena de anticorpos esta compensando o catabolismo, não deixando que exista uma queda 
pronunciada na curva de regressá, ao contrário, mantendo-a estável (Figura 4). Neste caso a produção endógena estaria mais visivel e atuante na flutuaçăo do nível de Ig G serica.

No tratamento 1 (1eite), bem como no tratamento 2, o maior desafio ao sistema imunologico, como ja foi discutido anteriormente, poderia ter evidenciado a migração de anticorpos séricos para o intestino, o que provocaria redução nos niveis séricos de Ig e, tambem, estimulando a produção endógena de anticorpos.

4.3. Parâmetros séricos e desempenho

$$
\text { 4.3.1. Peso }
$$

Os dados referentes às pesagens dos animais estão apresentados na Tabela 13, com as pesos observados nas idades de 1 a 60 dias separados por tratamentos. Na Figura 5 estão apresentadas as variaçßes medias dos pesos, no decorrer do perfodo experimental. 
Tabela 13 - Pesos médios (kg) por tratamentos, no períado de 1 a 60 dias de idade.

\section{Tratamentos}

\section{Idade}

(dias)
1

Média
2

Media DP
3

Media DP

\begin{tabular}{rlll}
\hline 1 & $38,4 \pm 5,8$ & $38,0 \pm 6,6$ & $37,6 \pm 4,8$ \\
5 & $38,8 \pm 6,4$ & $40,1 \pm 5,3$ & $39,3 \pm 4,6$ \\
10 & $41,2 \pm 5,7$ & $41,7 \pm 5,5$ & $41,8 \pm 4,5$ \\
15 & $40,4 \pm 4,6$ & $42,4 \pm 5,4$ & $44,2 \pm 4,3$ \\
20 & $42,7 \pm 4,6$ & $43,9 \pm 4,9$ & $44,9 \pm 3,5$ \\
25 & $44,5 \pm 5,5$ & $45,6 \pm 5,6$ & $46,5 \pm 4,7$ \\
30 & $45,2 \pm 4,4$ & $48,7 \pm 4,8$ & $48,7 \pm 4,9$ \\
40 & $48,1 \pm 3,1^{1}$ & $52,6 \pm 7,2^{3}$ & $50,7 \pm 3,6^{3}$ \\
50 & $53,6 \pm 6,7^{2}$ & $58,1 \pm 7,9$ & $59,2 \pm 6,3$ \\
60 & $60,2 \pm 6,9^{2}$ & $64,7 \pm 8,4$ & $70,7 \pm 7,0 *$ \\
\hline
\end{tabular}

TRAT 1 = Leite

TRAT 2 = Colostro 1 vez ao dia

TRAT $3=$ Colostro 2 vezes ao dia

$i_{n}=7$ (morte)

$z_{n}=6$ (morte)

${ }^{3} n=7$ los animais $n \stackrel{\circ}{1}$ deste trat. não foram pesados no $40^{\circ}$ dial.

* $a=5 \%$ 


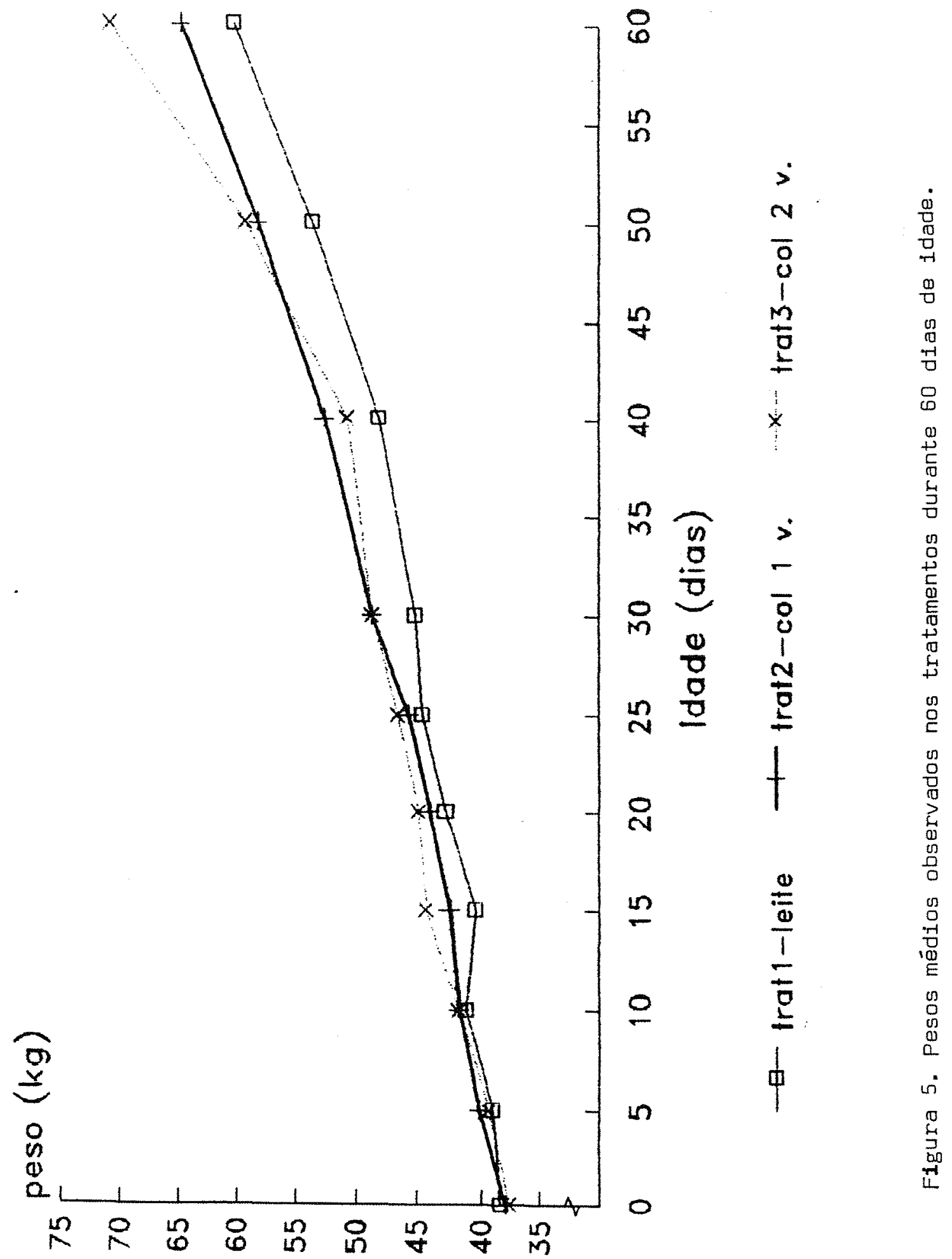


Atraves da análise de variáncia e da covariancia para experimentos em parcelas sub-divididas verificou-se que o peso medio final diferiu significativamente entre tratamentos $(p=0,0086)$ e que 0 peso inicial influiu no peso final observado $(p=0,0004)$. Tambem, verificou-se que a Ig G serica inicial (3 dias de idade) não influiu no peso final aos 60 dias de idade. a valor do peso final para o T3 (col. 2 vezes ao dia) foi maior que o do T1 (leite), ou seja, $70,7 \pm 7,0>60,2 \pm 8,9 \mathrm{~kg}$.

Na Tabela 14, está apresentados os ganhos de peso totais para cada animal nos trés tratamentos, além dos gantos de peso médios díarios.

Para ganto de peso, as análises de variáncia e covariância mostraram que houve diferença significativa $(p=0,0086)$ entre ganho de peso medio no total do período entre tratamentos, sendo que o peso inicial não influiu no ganho de peso total. Da mesma forma, a Ig G serica no $3^{\circ}$ dia de idade não influiu no ganto de peso medio total.

Através do teste Tukey verificou-se que o ganho de peso do T3 (colostro 2 vezes ao dia), foi estatisticamente superior ao do T1 (leite), ou seja: $33,12 \pm 5,23$ > $22,50 \pm 7,28 \mathrm{~kg}$ - 0 ganho de peso medio total para o T2 (colostro 1 vez ao dia) foi $26,69 \pm 4,38 \mathrm{~kg}$. 0 peso medio inicial não diferiu significativamente entre tratamentos. 
Tabela 14 - Ganho de peso ( $\mathrm{kg}$ ) total e diario dos animais em cada tratamento, de 1 a 60 dias de idade.

\begin{tabular}{|c|c|c|c|c|c|c|}
\hline Animais & $\begin{array}{l}\text { Trat } 1 \\
\text { Ganho } \\
\text { total } \\
(1-60 d)\end{array}$ & $\begin{array}{l}\text { (leite) } \\
\text { Ganho } \\
\text { medio } \\
\text { diario }\end{array}$ & $\begin{array}{l}\text { Trat } 2 \\
\text { Ganho } \\
\text { tota } 1\end{array}$ & $\begin{array}{l}\text { (col.1v) } \\
\text { Gantho } \\
\text { médio } \\
\text { diário }\end{array}$ & $\begin{array}{l}\text { Trat } 3 \\
\text { Ganho } \\
\text { total }\end{array}$ & $\begin{array}{l}\text { (col . 2v) } \\
\text { Ganho } \\
\text { medio } \\
\text { diario }\end{array}$ \\
\hline 1 & 22,5 & 0,37 & 31,5 & 0,52 & 35,0 & 0,58 \\
\hline 2 & 26,5 & 0,44 & 29,5 & 0,49 & 32,5 & 0,54 \\
\hline 3 & -1 & - & 24,5 & 0,41 & 39,5 & 0,66 \\
\hline 4 & -1 & - & 19,0 & 0,32 & $2 \theta, 0$ & 0,47 \\
\hline 5 & 18,0 & 0,30 & 24,5 & 0,41 & 41,0 & 0,68 \\
\hline 6 & 17,0 & 0,28 & 26,0 & 0,43 & 27,0 & 0,45 \\
\hline 7 & 16,0 & 0,27 & 26,0 & 0,43 & 28,5 & 0,47 \\
\hline $\mathbf{B}$ & 35,0 & 0,58 & 32,5 & 0,54 & 33,5 & 0,56 \\
\hline Média & $22,50 *$ & $0,37 *$ & 26,69 & 0,44 & 33,12 * & $0,55 *$ \\
\hline$D P( \pm)$ & 7.28 & 0,11 & $4,3 B$ & 0,07 & 5,23 & 0,08 \\
\hline
\end{tabular}

1 Amostras perdidas em funçăo da morte destes animais antes dos 60 dias de idade.

* Diferença significativa $(p=0,05)$

DP = desvio padrão

Os valores médios de ganho de peso encontrados neste trabalio estão de acordo com valores da literatura para bezerros recebendo apenas leite e colostro congelado (FOLEY \& OTTERBY, 1978; NOCEK et a $1 ., 1984$ ).

Não houve diferença significativa entre tratamentos para ganho de peso medio diario no periodo de 1 a 30 dias. No perfodo de 30 a 60 dias, a análise de variáncia mostrou diferença entre tratamentos, sendo a ganho do T3 
$(0,74 \pm 0,14 \mathrm{~kg}$ de ganho medio/dia) superior estatisticamente ao do $T_{1}(0,52 \pm 0,18 \mathrm{~kg}$ ganho medio/dia). O T2 apresentou $0,53 \pm 0,16 \mathrm{~kg}$ de ganho medio/dia.

As medias de ganho de peso diário medio no períado de 1 a 30 dias foram: $T 1=0,225 \pm 0,11 ; T 2=0,355$ $\pm 0,13$ e $T 3=0,370 \pm 0,11 \mathrm{~kg}$. Este fato evidencia que 0 ganho de peso começou a diferir após as 30 dias de idade, quando os animais ganham peso mais rapidamente.

Durante a fase experimental de campo, devido à ausencia de dados de consumo de MS de concentrado e feno pelos bezerros e, tambem, conhecendo-se as limitaçzes de se trabalhar com dados de ganho de peso com pequeno número de unidades experimentais, ressalta-se a existência de vários trabalhos onde foram monitorados centenas de bezerros leiteiros, controlando-se a ingestão de todos os alimentos, o que permite sugerir algumas possibilidades que expliquem as causas da diferença de ganho de peso entre tratamentos neste experimento; o caso de Allen ; Gaunya et al. ${ }^{2}$; Muller et al. ${ }^{3}$ : Owen et al. ${ }^{4}$ e Sutton \& Kaeser ${ }^{5}$, citados por FOLEY \& OTTERBBY (1978).

${ }^{1}$ ALLEN, N.N. Colustrum milk for calf feeding. I. Stored colostrum as a substitute form marketable milk for feeding dairy calves. Vermont Agr. Exp. Sta. Bull., Vermont, 544: 2, 1948 .

2GAUNYA, W.S.; MOCHRIE, R.D.; EATON, H.D.; JOHNSON, R.E. Colostrum as a substitute for whole milk in a limited whole milk feeding system. J. Dairy Sci.,, Champaign, 37: 655,1954 .

3MULLER, L.D.; OWENS, M.J.; BEARDSLEY, G.L.; SCHINGOETHE, D.J. Colostrum, whole milk, and whole milk plus whey protein concentrated for Holstein calves. J. Dairy Sci., Champaign, 57: 319, 1974. 
Estes trabalhos afirmam que bezerros alimentados com colostro armazenado por congelamento ganharam peso mais rapidamente do que aqueles alimentados com leite, em igual quantidade (em peso), refletindo o mais alto teor de solidos totais do colostro. Este fato pode ser evidenciado por estudos citados na revisão de FoLEY \& OTTERBY (1978), onde os bezerros que receberam a mistura de colostro e leite mais rica em solidos totais até 21 dias de idade ganharam mais peso, consumindo mais feno e menos concentrado. Ds mesmos autores afirmaram que quando quantidades iguais de solidos são oferecidas aos bezerros nas dietas 11 quidas o consumo de concentrado e geralmente semelhante para bezerros alimentados com leite ou colostro; no entanto quando existe recusa considerável da dieta 11 quida o consumo de concentrado também diminui. Tambén Allen ${ }^{1}$, citado por FOLEY \& OTTERBY (1978), fornecendo dietas 11 quidas com quantidades iguais de solidos totais, tanto no colostro como no leite, por bo dias, verificou gantos de peso similares para os bezerros de ambas as dietas. Entretanto, MARSHAL \& SMITH (1970), fornecendo colostro ou leite à vontade, verificaram que o consumo de dieta liquida aumentou en detrimento do consumo da dieta solida, porém os bezerros que tomaram leite

\footnotetext{
${ }^{4}$ OWEN, F.G.; PLUM, M.; APPLEMAN, R.D. Colostrum fed warm or cold until weaning of calves on once-a-day feeding program. J. Dairy Sci., Champaign, 53: 674, 1970.

${ }^{5}$ SUTTON, T.S. \& KAESER. Some physiological effects of extending the colostrum feeding period of dairy calves. J. Dairy Sci., Champaign, 29: 13, 1946.
} 
gantaram mais peso que aqueles que tomaram colostro, provavelmente pelo decrescimo da digestibilidade ou do consumo dos nutrientes energeticos (lactose e gordura) do colostro. Por outro lado, Owen et al.", citados por FOLEY \& OTTERBY (1978), encontraram maiores ganhos de peso em bezerros alimentados com colostro congelado ao inves de leite, mas no primeiro caso os bezerros consumiram mais concentrado, o que também ocorreu em outro trabalho de Owen et a1.4, porém apenas quando cessou o fornecimento das dietas 11 quidas.

VAN HORN et al. (1976) e Gwen et al.", citados por FOLEY \& OTTERBY (1978), trabalharam com o fornecimento de dietas de colostro duas vezes e uma vez ao dia, os primeiros não verificaram diferenças no ganho de peso, mas os segundos afirmam que os bezerros que receberam a dieta uma vez ao dia ganharam mais peso.

Após estas consideraçôs, pode-se supor que o maior ganto de peso observado nos animais do tratamento 3 , no total do periodo experimental, ocorreu en funça do fornecimento adicional de colostro por 30 dias de vida, representando uma fonte mais rica em solidos totais (FOLEY \& OTTERBY, 1978 e NOCEK, 1984), o que está de acordo com Gaunya et al. 2, citados por FOLEY \& OTTERBY (1978), que observaram maiores gantos de peso em bezerros alimentados com colostro, ao invés de leite, apesar das dietas totais fornecidas não apresentarem diferenças significativas entre si. 
Outro fator importante pode ser o de que no tratamento 3 os animais tiveram menor incidencia de diarreia, supostamente pela melhor distribuiçăo diáia de Ig G adicional no trato digestivo e, talvez, por apresentarem maiores teores de Ig G sistêmica (SNODGRASS \& WELLS, 1978; SAIF \& SMITH, 1985). Esta situação pode ter determinado uma proteça mais eficiente aos animais do Tratamento 3 , fazendo com que os nutrientes adicionais fossem aproveitados para ganho de peso e não desviados para os mecanismos de defesa, mais requisitados em situaçßes de diarréia severa.

O ganho de peso dos animais do tratamento 2 não diferiu do ganho de peso daqueles do tratamento 1 , mesmo recebendo colostro adicional, provavelmente porque houve maior severidade na diarréia, fazendo com que os animais perdessem peso, o que se refletiu no ganho total aos 60 dias de idade. Realmente, foi verificado estado febril, inapetência e disposição anormal dos animais nos periodos com diarréia, o que deve ter agravado a perda de peso no Tratamento 2. Quanto à tendencia para igualdade entre tratamentos 2 e 3, para ganho de peso total, pode ser explicada pelo fornecimento do colostro adicional, representando uma fonte mais rica de nutrientes, minimizando problemas de redução de consumo e perda de peso no tratamento 2.

Foram traçadas equaçßes de regressão linear para cada tratamento, expressando o comportamento da variavel peso en função da idade e da concentração de Ig $G$ 
serica dos animais. A correlaçăo entre peso e idade foi significativa e positiva durante todo periodo experimental: $r=0,80$.

As equaçöes de regressão foram as seguintes: T1 (leite) $=$ Peso $=34,75+0,36$. idade + $0,044$. Ig G, onde $R^{2}=0,55$ e QMR $=30,74$. o valor 0,044, que multiplica Ig G, nã foi significativo, não expressando - valor dos pesos na equação.

T2 (colostro 1 vez ao dia): Peso $=30,15+$ $+0,46$. idade $+0,207$. Ig G, onde $R^{2}=0,68$ e $\mathrm{AMR}=33,69$. Neste tratamento houve influencia da Ig G sobre a peso durante o periodo experimental $1 p=0,0065$ para $a$ valor $0,207)$

T3 (colostro 2 vezes ao dia): Peso $=27,66+$ $+0,57$. idade $+0,180$. Ig G, onde $R^{2}=0,78$ e $\operatorname{QM} R=26,29$, sendo que neste tratamento, tambem, houve influencia da Ig $G$ serica sobre o peso no periodo experimental ( $p=0,0109$ para o valor 0,180 ).

Em relação à influência das imunoglobulinas séricas nas 24-49 horas de vida sobre o gantio de peso, NOCEK et al-(1984) verificaram que o efeito foi positivo até o 4 ㅇ dia de vida, porém, năo significativo no ganto de peso de 5 a 11 dias e 5 a 45 dias. Os animais que receberam colostro inicial com altos niveis de anticorpos ganharam mais peso até 0 으 dia de idade $e$, aqueles que receberam colostro inicial pobre em anticorpos perderam peso neste 
período, o que está de acordo com MACHADO NETO et al. (1989).

EDWARDS et a1. (1982), tambem não encontraram correlação entre os niveis sericos de anticorpos nas 48 horas de vida e o ganho de peso diário até o desmame. Os autores afirmaram que quando o nivel inicial de anticorpos sericos absorvidos do colostro e maior que os niveis necessarios năo há influencia deste parámetro sobre o ganho de peso, o que tamberm foi observado neste traba1 ho.

ROBISON et al. (1988) encontraram efeito positivo da concentração sérica de anticorpos no perído de 24-49 horas de vida sobre o ganho de peso dos animais do nascimento até 180 dias, sendo este efeito mais intenso dos 70 aos 105 dias. Neste trabaliho, a concentração media de Ig G sérica abservada nas $24-48 h$ de vida foi de $25,71 \mathrm{mg} / \mathrm{ml}$ $( \pm 19,06)$, enquanto que no trabal ho de EDWARDS et al. (1982), esse valor foi de $60,08 \mathrm{mg} / \mathrm{ml}$ para bezerros que mamaram colostro ate 6 horas de vida e de $33,80 \mathrm{mg} / \mathrm{ml}$ para aqueles que foram ajudados a mamar apos as primeiras 6 horas de vida. 


\subsubsection{Diarréia}

Os dados relativos às notas médias diárias de cor e consistência das fezes dos animais, bem como a flutuação destas notas em cada tratamento, estão apresentados nas Tabelas 15 e 16 e ilustrados nas Figuras 6 e 7 .

Levando-se en consideração os parámetros analisados nas fezes, constatou-se que todas as unidades experimentais de cada tratamento apresentaram periodos de diarreia. Nos dias en que foram determinadas notas para cor de fezes maiores ou iguais a 2,0 e/ou notas para consistencia maiores ou iguais a 1,5 , considerou-se que os animais apresentavan fezes anormais (Figuras 8 e 9). Estas notas classificaram as fezes, no minimo, como semi-1Lquidas e de cor bege ou amarela, tambem, com grande quantidade de muco. Estas caracteristicas básicas para identificação de diarréia estão de acordo com De LEEUW et a1. (1980); SAIF et a1. (1983); BELLINZONI et al. (1989); CASTRUCCI et al. (1989) e TSUNEMITSU et a $1 .(1989)$.

Atraves dos testes usados para analisar dados não parametricos, $x^{2}$, KRUSKAL-WALLIS, WILCOXON, pertencentes ao SAS e testes do SENP (CIAGRI), verificou-se que para ambas caracteristicas de fezes, cor e consistencia, houve diferença significativa $(p<0,05)$ entre tratamentos para notas médias, nas seguintes idades experimentais: $9,13,15$, 
Tabela 15 - Notas medias diárias de cor de fezes durante 30 dias por tratamentos.

\begin{tabular}{|c|c|c|c|c|c|c|}
\hline \multirow{2}{*}{$\begin{array}{l}\text { Idade } \\
\text { (dias) }\end{array}$} & 1 & & \multicolumn{2}{|c|}{ Tratamentos } & \multicolumn{2}{|l|}{3} \\
\hline & Media & DP & Media & $\mathbf{D P}$ & Media & DP \\
\hline 3 & $0,69 \pm$ & 0,50 & $0,50 \pm$ & 0,00 & $0,50 \pm$ & 0,00 \\
\hline 4 & $0,81 \pm$ & 0,75 & $0,44 \pm$ & 0,16 & $0,31 \pm$ & 0,24 \\
\hline 5 & $0,50 \pm$ & 0,43 & $0,37 \pm$ & 0,22 & $0,31 \pm$ & 0,24 \\
\hline 6 & $0,50 \pm$ & 0,43 & $0,37 \pm$ & 0,22 & $0,31 \pm$ & 0,24 \\
\hline 7 & $0,87 \pm$ & 0,89 & $0,50 \pm$ & 0,79 & $0,25 \pm$ & 0,25 \\
\hline 8 & $1,12 \pm$ & 0,96 & $0,75 \pm$ & 0,90 & $0,50 \pm$ & 0,79 \\
\hline 9 & $1,87 \pm$ & 0,89 & $1,12 \pm$ & 1,11 & $0,62 \pm$ & 0,93 \\
\hline 10 & $1,37 \pm$ & 1,11 & $1,69 \pm$ & 1,00 & $0,94 \pm$ & 1,10 \\
\hline 11 & $1,81 \pm$ & 0,79 & $1,37 \pm$ & 0,99 & $1,44 \pm$ & 1,01 \\
\hline 12 & $2,31 \pm$ & 0,35 & $2,12 \pm$ & 0,70 & $1,94 \pm$ & 0,39 \\
\hline 13 & $2,19 \pm$ & 0,43 & $2,44 \pm$ & 0,16 & $1,94 \pm$ & 0,30 \\
\hline 14 & $2,12 \pm$ & 0,33 & $2,31 \pm$ & 0,24 & $1,81 \pm$ & 0,70 \\
\hline 15 & $2,44 \pm$ & 0,30 & $2,12 \pm$ & 0,33 & $1,81 \pm$ & 0,24 \\
\hline 16 & $2,25 \pm$ & 0,43 & $1,50 \pm$ & 0,90 & $1,69 \pm$ & 0,70 \\
\hline 17 & $2,00 \pm$ & 0,25 & $1,56 \pm$ & 0,95 & $1,19 \pm$ & 0,66 \\
\hline 18 & $1,56 \pm$ & 1,01 & $1,56 \pm$ & $0, \mathbf{8 5}$ & $1,12 \pm$ & 0,82 \\
\hline 19 & $0,87 \pm$ & 0,96 & $0,94 \pm$ & 1,01 & $0,94 \pm$ & 0,81 \\
\hline 20 & $1,12 \pm$ & 0,96 & $0,94 \pm$ & 0,84 & $1,25 \pm$ & 0,87 \\
\hline 21 & $0,31 \pm$ & 0,56 & $0,75 \pm$ & 0,79 & $1,44 \pm$ & 0,73 \\
\hline 22 & $0,37 \pm$ & 0,65 & $1,56 \pm$ & 0,81 & $1,37 \pm$ & 0,89 \\
\hline 23 & $0,62 \pm$ & 0,82 & $0,81 \pm$ & 0,83 & $1,00 \pm$ & 0,90 \\
\hline 24 & $0,56 \pm$ & 0,98 & $0,75 \pm$ & 0,87 & $1,12 \pm$ & 0,74 \\
\hline 25 & $0,81 \pm$ & 0,83 & $0,94 \pm$ & 0,73 & $0,62 \pm$ & 0,86 \\
\hline 26 & $0,44 \pm$ & 0,77 & $0,81 \pm$ & 0,86 & $1,25 \pm$ & 0,83 \\
\hline 27 & $0,62 \pm$ & 0,82 & $0,87 \pm$ & 0,74 & $0,69 \pm$ & 0,97 \\
\hline 28 & $0,25 \pm$ & 0,66 & $0,81 \pm$ & 0,66 & $0,56 \pm$ & 0,77 \\
\hline 29 & $0,87 \pm$ & 0,70 & $0,44 \pm$ & 0,58 & $0,00 \pm$ & 0,00 \\
\hline 30 & $0,56 \pm$ & 0,73 & $0,87 \pm$ & 0,70 & $0,19 \pm$ & 0,50 \\
\hline
\end{tabular}

TRAT 1 = Leite

TRAT 2 = Colostro 1 vez ao dia

TRAT $3=$ Colostro 2 vezes ao dia

DP = desvio padrão 


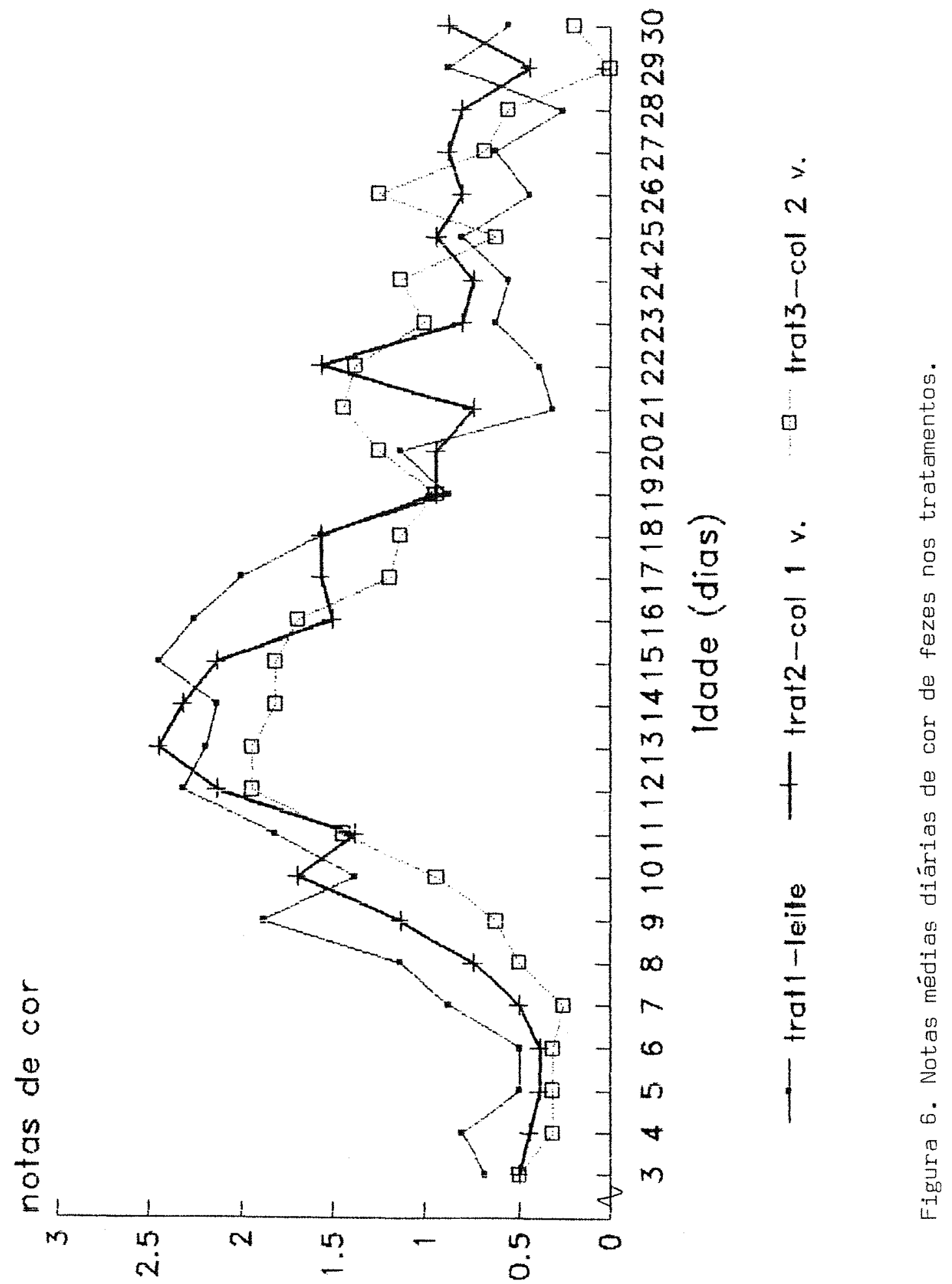


Tabela 16 - Notas medias diárias de consistencia de fezes durante 30 dias por tratamentos.

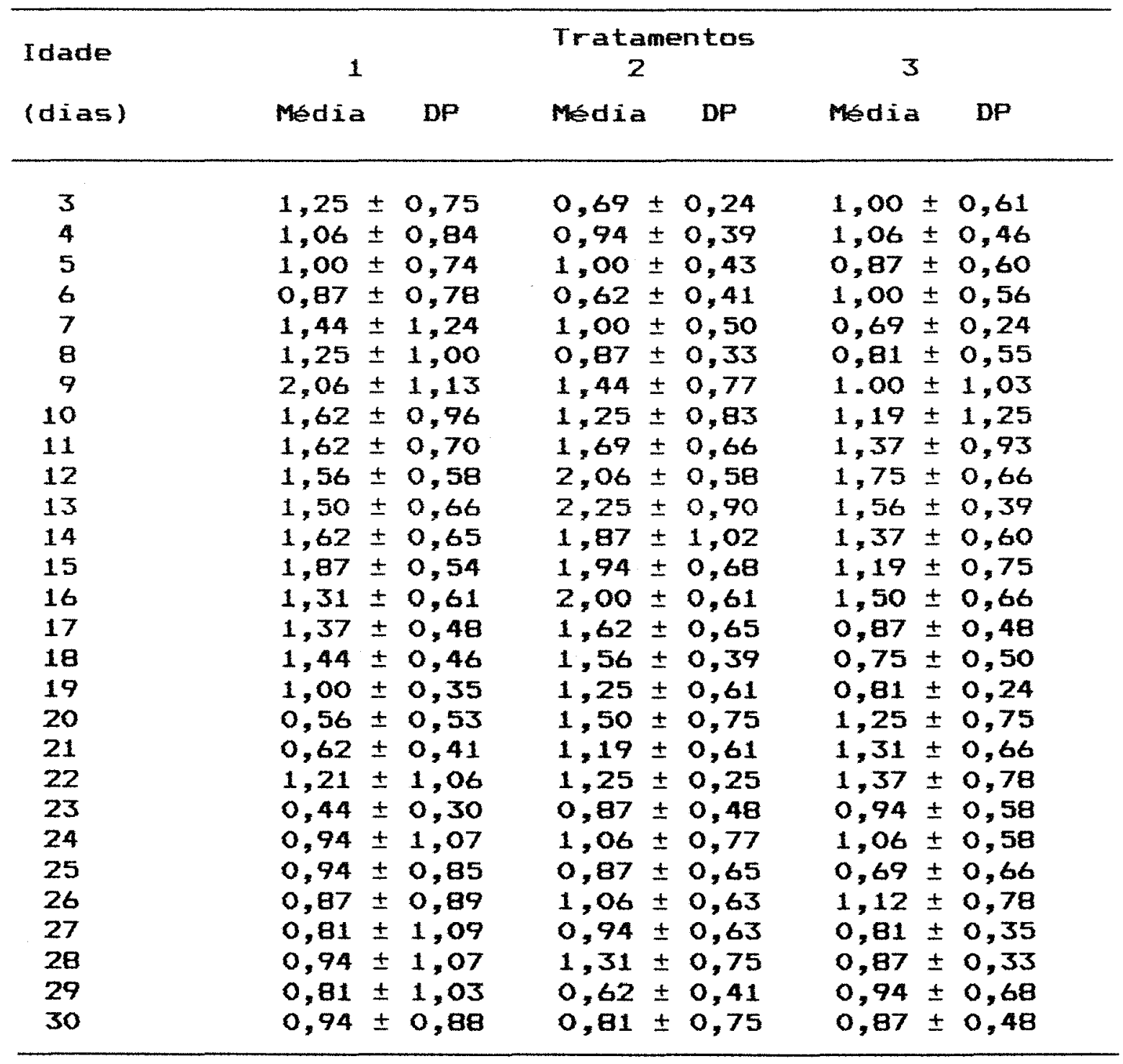

TRAT $1=$ Leite

TRAT 2 = Colostro 1 vez ao dia

TRAT $3=$ Colostro 2 vezes ao dia

DP = desvio padrão 


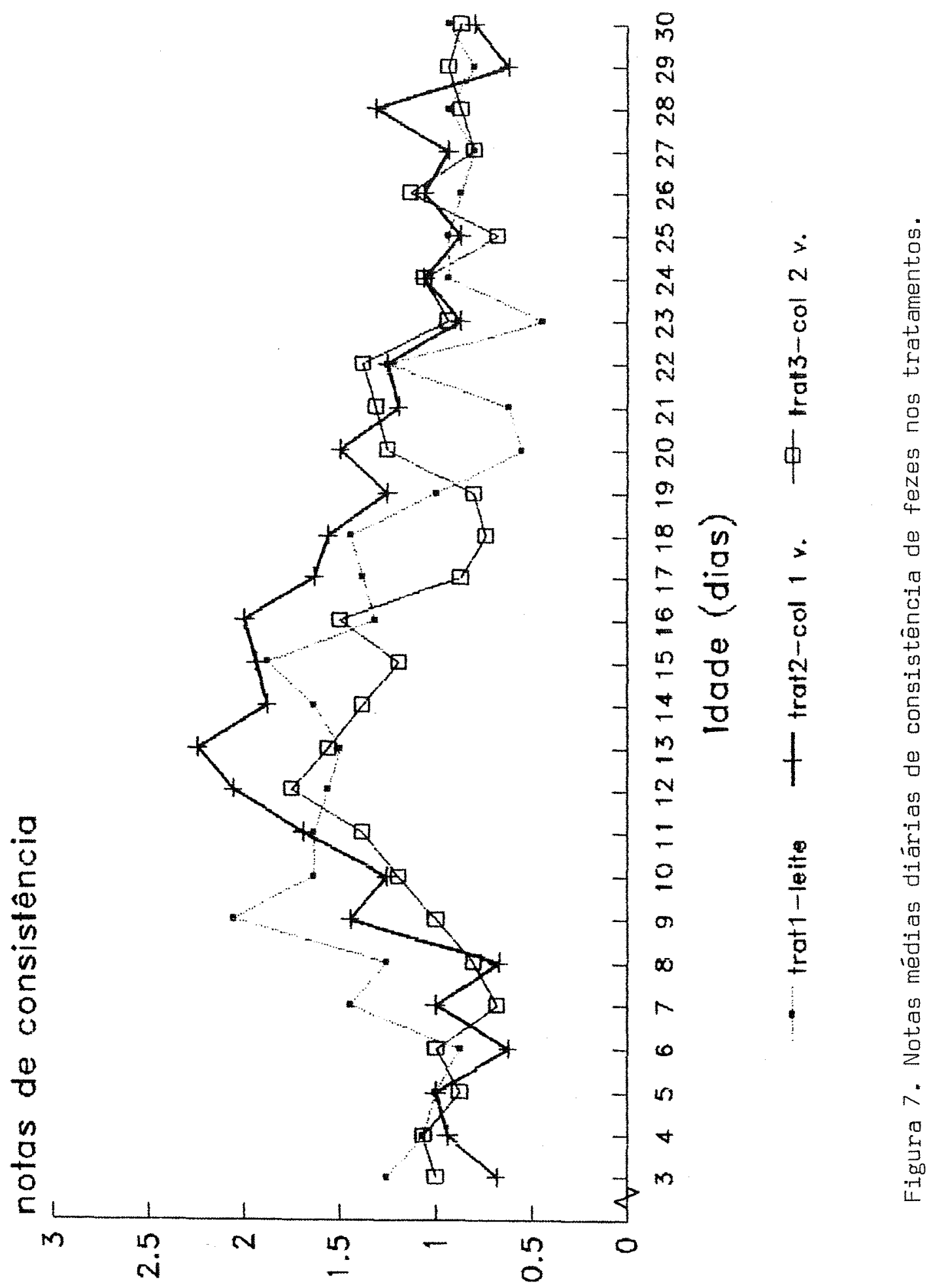




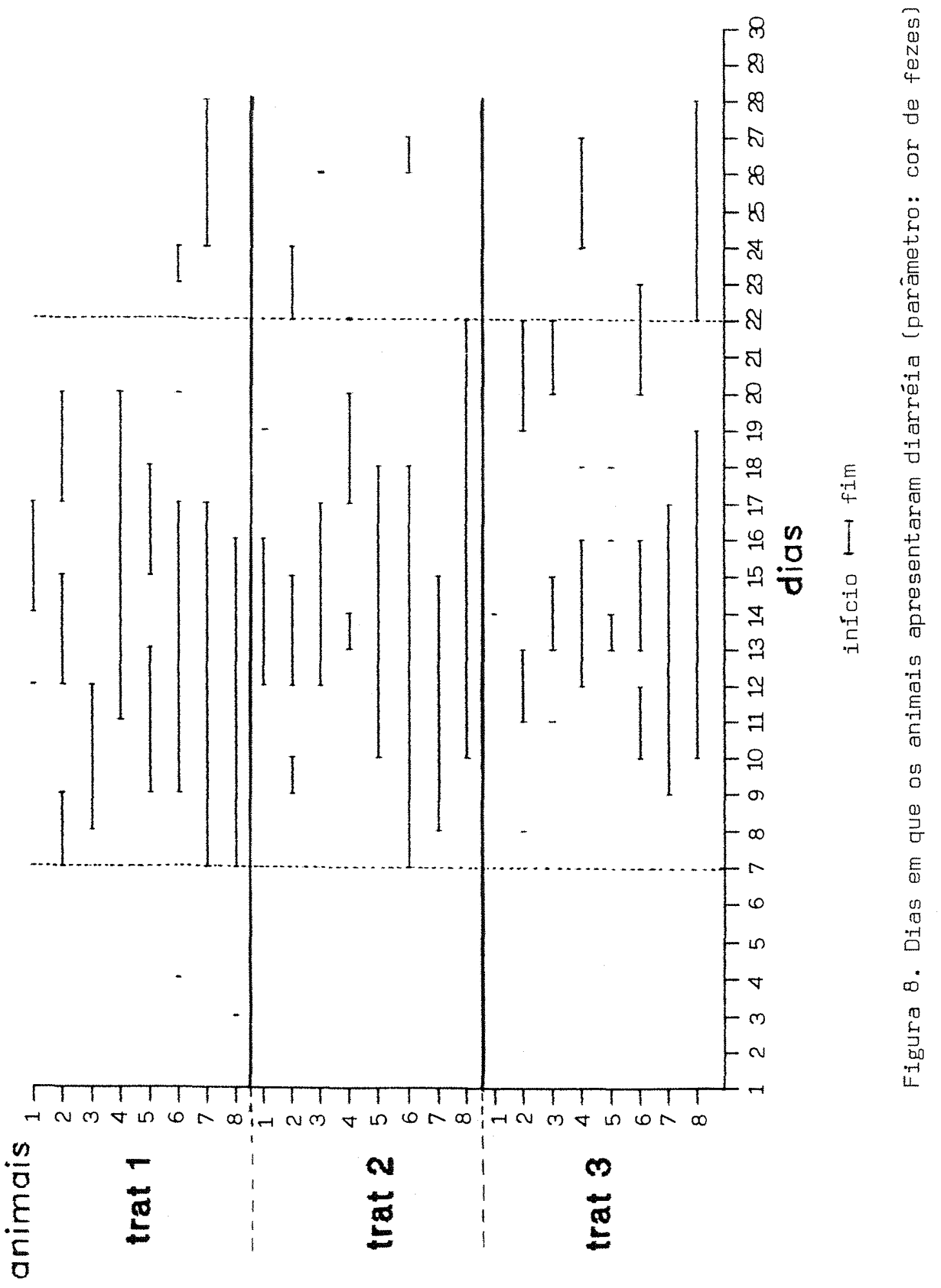




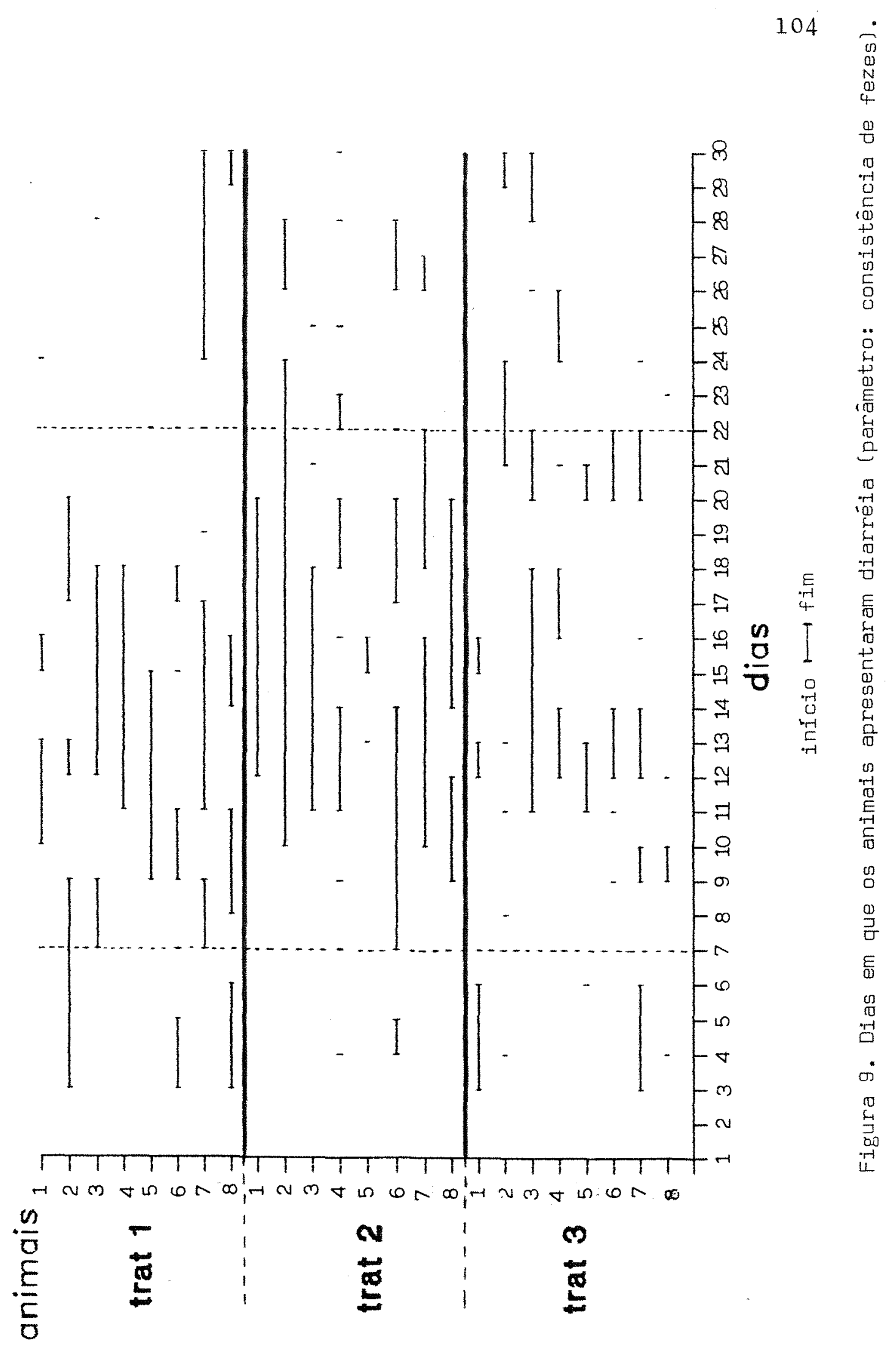


$17,18,20,21$ e 22 dias. Na maioria destas idades, a diarréia mostrou maior severidade no tratamento 2 ccolostro 1 vez ao dia), seguido pelo tratamento 1 (leite), com pequena diferença entre os mesmos. A menor severidade de diarreia, por idades, foi apresentado pelo tratamento 3 (colostro 2 vezes ao dia).

Quando dividiu-se o periodo experimental total em três sub-periodos: 3 a 10 dias; 11 a 20 dias e 21 a 30 días e procedendo-se a análise de dados não parametricos pelo SENP (CIAGRI), verificou-se que apenas para a caracteristica fecal de consisténcia houve diferença significativa entre tratamentos, no subperiodo de 11 a 20 dias de idade. Nesta fase houve maior ocorrencia de diarreias (Figuras $B$ e 7 ), indicando ataque por virus à mucosa intestinal, o que ests de acordo com Morin et al.

(1978) e SAIF \& SMITH (1985). Atraves do teste de comparaçठes múltiplas verificou-se que a consistencia fecal média neste sub-periodo apresentou nota superior no tratamento 2 (colostro 1 vez) en relaçăo aos tratamentos 1 (1eite) e 3 (colostro 2 vezes), indicando a maior severidade de diarréia no tratamento 2 (colostro 1 vez), como mostra a Tabela 17. Novamente, evidencia-se a superioridade no desempenho dos animais do tratamento 3 pela menor severidade de diarréia. 
Tabela 17 - Comparaçăo entre tratamentos no sub-periodo de 11 a 20 dias de idade para as notas medias de consistência fecal.

\begin{tabular}{|c|c|c|c|c|c|}
\hline \multirow[t]{2}{*}{$\begin{array}{l}\text { Sub-periodo } \\
\text { (dias) }\end{array}$} & $\begin{array}{l}\text { TRAT } 1 \\
\text { (leite) }\end{array}$ & \multirow{2}{*}{\multicolumn{2}{|c|}{$\begin{array}{c}\text { TRAT } 2 \\
\text { (Col. } 1 \text { vez) } \\
\text { Media DP }\end{array}$}} & \multirow{2}{*}{$\begin{array}{r}\text { TRAT } \\
\text { (col. } 2 \\
\text { Media }\end{array}$} & \multirow{2}{*}{$\begin{array}{l}3 \\
\text { vezes) } \\
\text { DP }\end{array}$} \\
\hline & Média & & & & \\
\hline $3-10$ & $1,32 \pm 0,36$ & $0,98 \pm$ & 0,25 & $0,95 \pm$ & 0,15 \\
\hline $11-20$ & $1,39 \pm 0,35 *$ & $1,78 \pm$ & $0,29 * ; *$ & $1,24 \pm$ & $0,32 *$ \\
\hline $21-30$ & $0,86 \pm 0,20$ & $1,00 \pm$ & 0,20 & $1,00 \pm$ & 0,21 \\
\hline
\end{tabular}

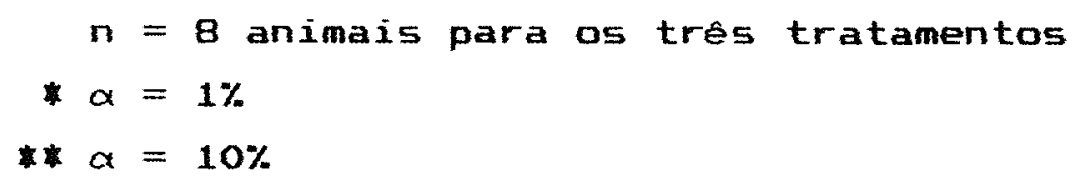

Houve correlação significativa positiva entre notas de cor e consistência fecais $(r=0,52)$, năo havendo, porém, correlaçơes significativas entre cor e consisténcia e parâmetros séricos. Todavia, apenas como interesse fisiologico, ressalta-se que as notas de parametros fecais variaram inversamente aos niveis de proteinas e imunoglobulinas séricas $e$ aos dados de peso, o que pode significar que maior severidade na diarréia possa ter ocorrido, tambem, en função de menores concentraçöes de anticorpos séricas, alén de outros fatores, vindo a afetar adversamente o ganho de peso (BRIGNOLE \& STOTT, 1980; RIBEIRO et a1., 1983). 
Atraves dos testes de KRUSKAL-WALLIS verificou-se que não houve diferença significativa entre tratamentos para o infcio e duração da diarréia, sendo as idades medias para o infcio da diarréia 8,12 dias para o tratamento 1; 10,12 dias para o tratamento 2 e 10,90 dias para o tratamento 3 no parámetro cor de fezes; enquanto o infeio para o parâmetro consistência foi aos 6,62 dias para T1; 9,12 dias para T2 e 6,50 dias para T3. Para a duração média de diarréia, no parámetro cor tem-se 10,25 dias no T1; 9,12 dias no $T 2$ e 8,25 dias no $T 3$, enquanto no parâmetro consisténcia, o número de dias para duração média foi 11,$25 ; 12,40$ e 9,50, respectivamente nos tratamentos 1, 2 e 3.

o fato de a menor severidade de diarréa ter sido observada na tratamento 3 pode ser explicado da seguinte maneira: camo os niveis sericos de imunoglobulinas foram semelhantes entre tratamentos, a não ser no $15^{\circ}$ e $17^{\circ}$ dias, apresentando uma tendencia à variaçăo no 5 o dia de vida $(p=0,0587)$, a proteção local parece ter sido mais importante do que a sistémica. Além do que, a alta concentraçăo de anticorpos séricos observada em todos os animais durante o experimento, refletindo um ótimo manejo da propriedade em relação ao monitoramento dos recém-nascidos (EDWARDS et al., 1982), não foi capaz de manter os animais livres da doença, podendo, apenas, ter contribus do para que ela não atingisse niveis muito altos de severidade 
GRASS \& WELLS, 1976; SNODGRASS \& WELLS, 1978; LINNABARY \& DEAN, 1983; MCNULTY \& LOGAN, 1987).

o efeito do colostro suplementar, mesmo proveniente de vacas não imunizadas pré-parto contra vírus e bacterias causadores de diarréia, pode prover anticorpos ao animal no período pós absortivo suficientes para exercer proteção local eficaz, diminuindo a severidade de diarreia causada por patógenos, o que está de acordo com SNODGRASS \& WELLS (1978), BRIGNOLE \& STOTT (1980), SAIF et al. (1983); SAIF \& SMITH (1985); CASTRUCCI et al. (1989); MACHADO NETO et al. (1989) e TSUNEMITSU et al. (1989). Alem do que, a Ig Gi suplementar presente na mucosa intestinal, proveniente do colostro, pode ser ativa no combate aos patógenos desde que ficou comprovada sua resisténcia à proteólise no lúmen, similarmente à Ig A bovina (NEWBY \& BOURNE, 1976a). O fato do tratamento 1 , sem fornecimento de colostro adicional, não ter tido o pior resultado em relaçăo à diarréia, pode ter sido em função do alto nivel de anticorpos séricos apresentados nestes animais, como já foi discutido anteriormente, podendo ter havido migração de Ig G sérica para a mucosa intestinal, como comprovado em NEWBY \& BOURNE (1976b), BESSER et al. (1987) e BESSER et al, (1988b), provendo uma proteçăo parcial contra diarréia mais severa. 
Por outro 1ado, o tratamento 2, mesmo recebendo colostro adicional, pode ter mostrado o pior resultado quanto à severidade da diarréia, em funçáo da composição do colostro apresentar maior conteúdo de sólidos totais (M.S.) que o leite, no mesmo volume (FOLEY \& aTTERBY, 1978 e NOCEK et al., 1984), podendo levar a diarreia osmotica, predispondo a mucosa ao ataque mais severo de patógenos, agravando a diarréia e sua duração (SAUNDERS \& WIGGINS, 1981; NOCEK Et a1., 1984; HALL, 1987; RUMESSEN, 1988).

Porém, Foley \& OTTERBY (1978), em sua reviså, citam resultados que não verificaram aumento na diarréia devido ao fornecimento de colostro congelado em relação ao leite ou ao colostro diluido, inclusive com quantidades de colostro bem superiores do que as usadas neste experimento, ocorrendo, em alguns casos, até reduçå na diarréia.

Esta informação pode mostrar que $o$ agravamento da diarréia no tratamento 2 pode ter ocorrido em funçăo do menor nivel sérico de Ig G observado nos dias 15 e 17, ou ainda, mais provavelmente devido à pior distribuiçăo de Ig $G$ no trato digestivo obtida con o fornecimento de colostro apenas uma vez ao dia. Este fato mostra que para a proteção local mediada pelos anticorpos no lúmen ser realmente eficaz, e necessária uma distribuiçăo uniforme e presença continua das Ig $G$ junto aos enterócitos (SNODGRASS 
\& WELLS, 1978 ; DAUVERGNE et a1., 1983 e CASTRUCCI et al.; 1989), o que foi obtido no tratamento 3 , com fornecimento do colostro suplementar duas vezes ao dia.

A afirmação de que a distribuição de Ig 6 no trato digestivo foi mais adequada no tratamento 3 , pode ser reforçada pelo resultado da análise de variáncia feita para as quantidades médias diárias de Ig $G$ (gramas) fornecidas pelo colostro adicional a cada animal, onde năo houve diferença significativa entre os tratamentos 2 e 3 , quanto a essas quantidades. Desta forma, nåo havendo variaçăo na quantidade media de anticorpos fornecidos, provavelmente a maior influencia dos tratamentos se deu pela diferença na distribuição das imunoglobulinas no trato digestivo.

\subsection{Consideraçơes gerais}

o nivel de anticorpos absorvidos pela maioria dos animais após a ingestão de colostro foi alto, indicando um bom manejo da propriedade no monitoramento dos recémnascidos. Porén, alguns valores mais baixos de imunoglobulinas sericas passivas podem ter contribus do para uma maior variabilidade nos animais dentro dos tratamentos para esta variável, podendo ter interferido na sensibilidade dos resultados estats sticos obtidos. Nos próximos trabalhos deve-se proceder maior uniformizaçăo dos animais quanto ao 
nivel de anticorpos sericas iniciais absorvidos do colastro, o que deve ser feito antes de alocá-los aos tratamentos. En relação ao ganho de peso dos animais também deverá ser efetuado o controle da ingestão de todos os alimentos consumidos, principalmente do concentrado. Esta medida poderá trazer maior significância aos dados de ganho de peso e às prováveis causas de sua variaçăo, tornando mais completo o estudo realizado. 
5. CONCLUSOES

Tendo em vista os objetivos deste trabalho e as condiçós em que o mesmo foi realizado, pode-se concluir que :

- A concentração sérica inicial de imunoglobulinas apresentada pelos animais foi superior àquelas consideradas adequadas pela literatura para exercer proteção passiva eficaz, evidenciando o bom manejo da propriedade com as recém nascidos nas 24 primeiras horas de vida que pode ter contribuf do com alguma influencia sobre os efeitos reais dos tratamentos.

- Os altos niveis iniciais de imunoglobulinas séricas determinaram um prolongamento na fase de declínio na concentraçăo das mesmas, refletido também na protefna total sérica, em especial nos animais do tratamento 3.

- O aproveitamento do colostro misturado ao leite mostrou ser uma prática viável e eficiente para proporcionar boas condiçōes imunologicas local e sistémica, ao bezerro. 
- O fornecimento de calostro por periodo prolongado, duas vezes ao dia, proporcionou melhor desempenho dos animais, indicando maior proteção imunológica local, mediada pelos anticorpos suplementares presentes continuamente no lumen e maximização da imunidade sistêmica contra patógenos causadores de diarréa. 
REFERENCIAS BIBL IOGRAF ICAS

ACRES, S.D. Enterotoxin Escherichia cali infections in newborn calves: a review. J. Dairy Sci., Champaign, $6 \theta(1)=229-56,1985$.

AHLSTEDT, S.; CARLSSON, B.; HANSON, L.A.; GOLDBLUM, $R$. Antibody production by human colostrum cells. (1) Immunoglobulin class, specificity and quantity. Scand J. Immunol., 0510, 5 : 535-9, 1975 .

ANDERSON, B.C. Cryptosporidiosis: A review. I.A.V.M.A., Chicago, $180(12)=1455-7,1982$.

ARGENZ10, A. Digestão, absorçao e metabolismo. In: SWENSON, M.J. Dukey's physiology of domestic animals. $10^{\circ}$ ed., Ithaca, Cornell univ. Press, 1984 , cap. 3 , p. $263-4$.

AYERS, M.W. \& BESSER, T.E. Evaluation of colostral Ig G absorption in newborn calves after treatment with alkalinizing agents. Am. J.Vet. Res., Chicago, 53(1): $83-6$, 1992.

BANWELL, J.G. Pathophysiology of diarrheal disorders. Reviews of infections diseases, chicago, $12(1): 30-5$, 1990. 
BELLINZONI, R.C.; BLACKHALL; J.; BARQ, N.; AUZA, N.; MATtION, N.; CASARO, A.; LA TORRE, J.L.; SCODELLER, E.A. Efficacy of an inactivated oil-adjuvanted rotavirus vaccine in the control of calf diarrhoea in beef herds in Argentina. Vaccine, Surrey, $z: 263-8,1989$.

BESSER, T.E.; GAY, C.C.; PRITCHETT, L. Comparison of three methods of feeding colostrum to dairy calves. I. American Veterinary Medical Association. Chicago, $198(3)$ : $419-22,1991$.

BESSER, T.E.; MEGUIRE, T.C.; GAY, C.C. The transfer of serum Ig $G_{1}$ antibody into the gastrointestinal tract in newborn calves. Veterinary Immunology and Immunopathology, Amsterdam, 17: $51-6,1987$.

GESSER, T.E.; GARMEDIA, A.E.; MCGUIRE, T.C.; GAY, C.C. Effect of colostral immunoglobulin $G_{1}$ and immonuglobulin M concentration on immunoglobulin absorption in calves. J. Dairy Sci ., Champaign, 6 B $=2033-7,1985$.

BESSER, T.E.; GAY, C.C.; MCGUIRE, T.C.; EVERMANN, J.F. Passive immunity to bovine rotavirus infection associated with transfer of serum antibody into the intestinal lumen. Journal of Virology, Baltimore, $62(7)=2238-42$, 1988a .

BESSER, T.E.; MCGUIRE, T.C.; GAY, C.C.; PRITCHETT, L.C. Transfer of functional immunoglobulin $G(I g G)$ antibody into the gastrointestinal tract accounts for Ig 9 clearance in calves. Journal of Virology, Baltimore, $62(7): 2234-7,1988 b$. 
BOHL, E.H. Comments on passive immunity in rotavirus infections. J. American Veterinary Medical Association, Chicago, $193(5): 568-9,1978$.

BOURNE, J. \& NEWBY, T. Mucosal immunity. In Practice; London, $3(5): 5-11,1981$.

BRAMBELL, F.W.R. The passive immunity of the young mamma 1. Biol. Rev., Cambridge, $33=488-531,1958$.

BRANDON, M.R. \& LASCELLES, A.K. Relative efficiency of absorption of $\operatorname{Ig} G_{1}, I_{2} G_{2}, I g A$ and $I g M$ in the newborn calf. Aust. J. Exp. Biol. Med. Sci., Adelaide, 49: $629-33,1971$.

BRAUN, R.K. \& TENNANT, B.C. The relationship of serum gammaglobulin levels of assembled neonatal calves to mortality caused by enteric disorders. Agri-practice, Santa Barbara, $4(5)=14-24,1983$.

BRIGNOLE, T.J. \& STOTT, G.H. Effect of suckling followed by bottle feeding colostrum on immungglobulin absorption and calf survival. I. Dairy Sci., Champaign, $63=451-6$, 1980 .

BUSH, L.J. \& STALEY, T.E. Absorptoion of colostral immunoglobulins in newborn calves. J. Dairy Sci., Champaign, 63: $672-80,1980$.

BUSH, L.J.; AGUILERA, M.A.; ADAMS, G.D. Absorption of colostral immunoglobulins by newborn dairy calves. I. Dairy Sci., Champaign, s4: 1547-9, 1971 . 
BUSH, L.J.; MUNGLE, M.B.; CORLEY, L.D.; ADAMS, G.D. Factors affecting absorption of immunoglobulins by newborn dairy calves. J. Dairy Sci., Champaign, 56: 312-8, 1973.

BUTLER, J.E. Bovine immunoglobulins: A review.

I. Dairy Sci., Champaign, 52: 1895-1909, 1969.

CASTRUCCI, G.; FRIGERI, F.; FERRARI, M.; ALDRQVANDI, $V . ;$ TASSINI, F. Further studies on passive immunization of newborn calves against rotaviral infection. Comp. Immun. Microbiol. Infec. Dis., Great Britain, 12(3): 71-6, 1989 .

CRUYWAGEN, C.W. Effect of curd forming of colostrum on absorption of immungglobulin $G$ in newborn calves. J. Dairy Sci., Champaign, 73: 3287-90, 1990.

DAUVERGNE, M.; BRUN, A.; SQULEBOT, J.P. Passive protection of newborn calves against rotavirus by vaccination of their dams. Develop. biol. Standard, Lyon, 53: 245-55, 1983.

De LEEUW, P.W.; ELLENS, D.J.; TALMON, F.P.; ZIMMER, G.N. Rotavirus infections in calves: efficacy of oral vacination in endemically infected herds. Research in Veterinary Science, London, $29=142-7,1980$.

DEVERY, J.E.; DAVIS, C.L.; LARSON, B.L. Endogenous production of immunoglobulin $I_{g} G_{1}$ in newborn calves. I. Dairy Sci., Champaign, 62: 1814-8, 1979.

DIXON, F.J.; WEIGLE, W.O.; VAZQUEZ, J.J. Metabolism and mammary secretion of serum proteins in the cow. Lab. Invest., Baltimore, $10=216-36,1961$. 
DONOVAN, G.A.; BADINGA, L.; COLLIER, R.J.; WILCOX, C.J.; BRAUN, R.K. Factors influencing passive transfer in dairy calves. J. Dairy Sci., Champaign, 69: 754-9, 1986.

EDWARDS, S.A.; BROOM, D.M.; COLLIS, S.C. Factors affecting levels of passive immunity in dairy calves. British Vetarinary Journal, London, $138(3): 233-40,1982$.

FAGLIARI, J.J.; FERREIRA NETO, J.M.; LUCAS, A.; NETO, J.A. Protel na total e fracionamento eletroforetico do soro de bezerros guzerá passivamente imunizados contra paratifo. Arq. Bras. Med. Vet. Zont., Belo Horizonte, 35: 317-32, 1983.

FETCHER, A.; GAY, C.C.; MCGUIRE, T.C.; BARBEE, D.D.; PARISH, S.M. Regional distribution and variation of gamma globulin absorption from the small intestine of the neonatal calf. Am. J. Vet.Res., Chicago, 44: 2149-54, 1983.

FISHER, E.W. \& MARTINEZ, A.A. The relationship between the zinc sulphate turbidity test, serum immune globulins and the suceptibility of calves to diarrhoea. Br. Vet. J., London, $134: 231-3,1978$.

FLEENOR, W.A. \& STOTT, G.H. Hydrometer test for estimation of immunoglobulin concentration in bovine colostrum. J. Dairy Sci., Champaign, 63 : 973-7, 1980.

FLEENOR, W.A. \& STOTT, G.M. Single radial immunodiffusion analysis for quantitation of colostral immunoglobulin concentration. J. Dairy Sci., Champaign, 64: 740-7, 1981 . 
FOLEY, J.A. OTTERBY, D.E. Availability, storage, treatment composition and feeding value of surplus colostrum. A Review. J. Dairy Sci., Champaign, 61: 1033-60, 1978.

GAY, C.C.; ANDERSON, N.; FISHER, E.W.; MCEWAN, A.D. Gamma 9 lobulin levels and neonatal mortaliry in market calves. Vet. Rec., London, $77: 148-9,1965$.

GUERRANT, R.L.; HUGHES, J.M.; LIMA, N.L.; CRANE, J. Diarrhea in developed and developing countries: magnitude, special settings and etiologies. Reviews of infectious diseases, Chicago, $12(1)=41-50,1990$.

GUYTON, A.C. Digestão e absorção no trato gastrointestinal e distúrbios gastrointestinais. In: W.B. SAUNDERS Co. Fisiologia Básica. $2^{a}$ ed. Rio de Janeira, Interamericana Edit., 1978. cap. 44.

HALL, G.A. Veterinary gastroesterology. In: POUNDER, R.E., ed. Recent advances in gastroenterology. London, Churchill Livingtone, $1986, n$ 으, $6.115-33$.

HALL, G.A. Comparative pathology of infection by novel diarrhoea viruses. In: CIBA FOUNDATION SYMPOSIUM, 128, wiley, 1987. Enteropathology of diarrhoea viruses. Chichester, Ciba Foundation, 1987. p.192-217.

HALL, G.A.; REYNOLDS, D.J.; PARSONS, K.R.; BLAND, A.P.; MORGAN, 3.H. Pathology of calves with diarrhoea in southern Britain. Research in Veterinary science. London, 45: 240-50, 1988 .

HAMMER, D.K. \& MOSSMAN, H. The importance of membrane receptors in the transfer immunaglobulins from plasm to the colostrum. Ann. Rech. Vet., Paris, 9: 229-34, 1978. 
HUSBAND, A.J. \& LASCELLES, A.K. Antibody responses to neonatal immunization in calves. Res. Vet. Sci." London, 18: $201-7,1975$.

HUSBAND, A.J.; BRANDON, M.R.; LASCELLES, A.K. Absorption and endogenous production of immunoglobulins in calves. Aust. J. Exp. Biol. Med. Sci., Adelaide, 50: 491-8, 1972.

JEFFCOTT, L.B. Passive immunity and its transfer with special reference to the horse Biol. Rev. Cambridge, $47: 439-64,1972$.

KLAUS, G.G.B.; BENNET, A.; JONES, E.W. A quantitative study of the transfer of colostral immunoglobulin to the newborn calf. Immunology, Oxford, 16: 293-9, 1969.

KRUSE, P.E. The importance of colostral immunoglobulin and their absorption from the intestine of the newborn animals. Am. Rech. Vet., Paris, 14(4): 349-53, 1983.

LANCE, S.E.; MILLER, G.Y.; HANDCOCK, D.D.; BARTLETT, P.C.; HEIDER, L.E.; MOESCHBERGER, M.L. Effects of environment and management on mortality in preweaned dairy calves. J.A.V.MA., Chicago, 201(日): 1197-1202, 1992.

LARSON, B.L.; HEARY Jr., H.L.; DEVERY, J.E. Immunoglobulin production and transport by the mammary gland. I. Dairy Sci., Champaign, 40: 377-80, 1980.

Le BLANC, M.M.; MCLAURIN, B.I.; BOSWELL, R. Relationships among serum immunoglobulin concentration in foals, colostral specific gravity and colostral immunoglobulin concentration. J.A.V.M.A., Chicago, 189(1):57-60, 1986. 
Le BLANC, M.M.; TRANT, T.; BALDWIN, J.L.; PRITCHARD, E.L. Factors that influence passive transfer of immunoglobulins in foals. J.A.V.M.A., Chicago, 200(2): 179-83, 1992.

LEVINE, N.D. Taxonomy and review of the coccidian genus Cryptosporidium (Protozoa, Apicomplexa). I. Protozool.; Lawrence, $31(1): 94-8,1984$.

LINGGOOD, M.A. \& PORTER, P. The antibody - mediated elimination of adhesion determinant from enteropathogenic strain of Escherichia coli. In: BERKELEY, R.C.W.; LYNCH, J.M.; MELLING, J.; RUTTER, P.R.; VINCENT, B.; ed. Microbial adhesion to surfaces. London, Ellis Horwood Limited, 1979. cap. 24, p.441-53.

LINNABARY, R.D. \& DEAN, D.F. Factors influencing neonatal dairy calf survival. Agri-practice, Santa Barbara, 4(5): $39-47,1983$.

LDGAN, E.F.; McBEATH, D.G.; LOWMAN, B.G. Quantitative studies of serum immunoglobulin levels in suckled calves from birth to five weeks. Vet. Rec., London, 94: $367-70,1974$.

LOGAN, E.F.; MCMURRAY, C.H.; O.NEIL, D.G.; MCPARLAND, P.J.; MCRORY, F.J. Absorption of colostral immunoglobulin by the neonatal calf. Br.Vet. J., London, 134: 258-62, 1978.

LUCCHELLI, A.; LANCE, S.E.; BARTLETT, P.B.; MILLER, G.Y.; SAIF, L.J. Prevalence of bovine group A rotavirus shedding among dairy calves in ohio. American J. Vetarinary Research, Chicago, $53(2): 169-74,1992$. 
MACH, J.P. \& PAHUD, J.J. Secretory Ig A, major immunoglobulin in must bovine external secretions. The Journal of Immunology, Baltimore, $106(2)=552-3,1971$.

MACHADO NETO, R. PACKER, I.U. Flutuação de imunologlabulina sérica em bezerros da raça holandesa submetidos a diferentes regimes de aleitamento. Revista da Sociedade Brasileira de Zootecnia, Viçosa, $15(5)=439-47$, 1986.

MACHADO NETO, R.; PACKER, I.U.; SUSIN, I.; NOLASCO, A.M. Protelna total sérica en bezerros da raça holandesa submetidas a diferentes regimes de aleitamento. Anais da E.S.A. "Luiz de Queiroz", Piracicaba, $43=265-83,1986$.

MACHADO NETO, R.; PACKER, I.U.; SUSIN, I. Concentraçăo de imonoglobulina sérica, peso corporal e diarréia, em bezerros da raça holandesa aleitados com diferentes dietas. Turrialba, Costa Rica, 39(1): 51-5, 1989.

MANCINI; G.; CARBONARA, A.O.; HEREMANS, J.F. Immunochemical quantitation of antigenus by single radial immunodiffusion. Immunochemistry, London, 2 : 235-54, 1965.

MARSHALL, S.P. \& SMITH, K.L. Effect of different milks and levels of intake upon, growth of young dairy calves. I. Dairy Sci., Champaign, 53: 1622, 1970.

MCCOY, G.C.; RENEAN, J.K.; HUNTER, A.G.; WILLIAMS, J.B. Effects of diet and time on blood serum proteins in the newborn calf. I. Dairy Sci., Champaign, $53=358-62$, 1970 . 
MCGUIRE, T.C.; PFEIFFER, N.E.; WEIKEL, J.M.; BARTSCH, R.L. Failure of colostral immunoglobulin transfer in calves dying from infections disease. J.A.V.M.A., Chicago, $169(7)=713-8,1976$.

MCNULTY, M.J. \& LOGAN, E.F. Effect of vaccination of the dam on rotavirus infection in young calves. Veterinary Record, London, $120=250-2,1987$.

MCNULTY, M.S.; MCFERRAN, J.B.; BRYSON, D.G.; LOGAN, E.F.; CURRAN, W.L. Studies on rotavirus infection and diarrhoea in young calves. Vet. Rec., London, 99 : $229-30,1976$.

MECHOR, G.D.; GROHN, Y.T.; VAN SAUN, R.J. Effect of temperature on colostrometer readings for estimation of immunoglobulin concentration in bovin colostrum. J. Dairy Sci., Champaign, $74=3940-3,1991$.

MICHANEK, P.; VENTORP, M.; WESTROM, B. Intestinal transmission of colostral antibodies in newborn dairy calves - initiation of closure by feeding colostrum. Swedish J. Agric. Res., Uppsala, 19: 125-7, 1989a.

MICHANEK, P.; VENTORP, M.; WESTROM, $B$. Intestinal transmission of macromolecules in newborn dairy calves of different ages at first feeding. Research in Veterinary Science, London, 46: $375-9,1989 \mathrm{~b}$.

MICHANEK, P.; VENTORP, M.; WESTROM, B. Milk intake before first colostrum in newborn dairy calves. Effect on intestinal transmission of macromolecules. J. Dairy Sci., Champaign, $73=480-3,1989 c$. 
MOON, H.W. MCDONALD, T.S. Antibody response of cows to Escherichia coli pilus antigen $K 99$ after oral vaccination with live or dead bacteria. Am.J.Vet. Res., Chicago, $\underline{44}(3)=49305,1983$.

MORGAN, J. Controlling diarrhoea in pourchased calves. Science and quality beef production - London, $\underline{5}: 2-3$, 1986 .

MORGAN, J. Epidemiology, diagnosis and control of undifferentiated calf diarrhoea. In Practice, London, $12(1): 17-20,1990$.

MORIN, M.; LARIVIERE, S.; LALLIER, R.; BEGIN, M.; ROY, R.; ETHIER, R. Neonatal calf diarrhoea: pathology and microbiology of spontaneous cases in dairy herds and incidence of the enteropathogens implicated as etiological agents. In: INTERNATIONAL SYMPOSIUM ON NEONATAL DIARRHEA, 2., Saskatoon, 1978. Proceedings, Saskatoon, Saskatchewan, 1978. p.347-67.

MULLER, L.D. \& ELLINGER, D.K. Colostral immunoglobulin concentration among breeds of dairy cattle. J. Dairy Sci., Champaign, 64: 1727-30, 1981 .

MURAKAMI, Y.; NISHIOKA, N.; EGUCHI, M.; KUNIYASU, $C$. Serotype - Specific antibody responses of calves infected naturally with bovine rotavirus. Jpn. J. Vet. Sci.; Tokyo, $52(1): 171-4,1990$.

MYERS, L.L. \& SNODGRASS, D.R. Colostral and milk antibody titers in cows vaccinated with a modified live rotavirus - coronavirus vaccine. J.A.V.M.A., Chicago, $181(5)=486-8,1982$. 
NAGURA, H.; NAKANE, P.K.; BROWN; W.R. Breast milk Ig A binds to jejunal epithelium in suckling rats. J. Immunol -, Baltimore, 120: 1330-9, 1978.

NEWBY, T.J. \& BOURNE, F.J. Relative resistance of bovine and porcine immunoglobulins to proteolysis. Immunoloqical Communications, Bristol, 5: 631-5, 1976 a.

NEWBY, T.J. \& BOURNE, F.J. The nature of the local immune system of the bovine small intestine. Immunology, Oxford, $\underline{31}=475-80,19766$.

NEWBY, T.J.; STOKES, C.R.; BOURNE, F.J. Immunalogical activities of milk. Vet. Imm. Immunop., Ansterdam, $\underline{3}$ : $67-94,1982$.

NOCEK, J.E.; BRAUND, D.G.; WARNER, R.G. Influence of neonatal colostrum administration, immunoglobulin, and continued feeeding of colostrum on calf gain, health, and serum protein. J. Dairy sci., Champaign, $67=$ 319-333, 1984.

OKERMAN, L. Enteric infections caused by non-enterotoxigenic Escherichia coli in animals: occurrence and pathogenicity mechanisms. A Review. Veterinary Microbiology, Ansterdam, 14:33-46, 1987.

OLSON, D.P.; BULL, R.C.; WOODARD, L.F.; KELLEY, K.W. Effects of maternal nutritional restriction and cold stress on young calves: absorption of colostral immunoglobulins. Am. J. Vet. Res., Chicago, 42: 876-80, 1981 .

OYENIYI, 0.0. \& HUNTER, A.G. Colostral constituents including immunoglobulins in the first three milkings postpartum . J. Dairy Sci., Chicago, 61: 44-8, 1978. 
PENHALE, W.J.; LOGAN, E.F.; SELMAN, I.E.; FISHER, E.W.; MCEWAN, A.D. Observations on the absorption of colostral immunoglobulin by neonatal calf and their significance in colibacilosis. Ann. Rech. Vet., Paris, 4 : 223-33, 1973.

PQRTER, P. Quantitatives changes in early lactation and absorption by the neonatal calf. Immunology, Oxford, $\underline{23}: 225-38,1972$.

PORTER, P. Structural and functional characteristics of immunoglobulins of the common domestic species. Adv. Vet. Sci. Comp. Med., New York, 23: $1-21,1979$.

PORTER, P.; KENWORTHY, R.; THOMSON, I. Oral immunization and its significance in the prophylactic control of enterits in the preruminant calf. Veterinary Record, London, $97: 24-30,1975$.

QUIGLEY, J.D. III. Management strategies to improve antibody absorption in calves. In: ALLTEEH'S SEVENTH ANIMAL SYMPOSIUM, 17, Kentucky, 1991. Proceedings. Kentucky, T.P. Lyons, 1991. P.277-91.

REINHOLD, J.G. Total protein, albumin and globulin. In: REINER, M. Standard methods of clinical chemistry. New York, Academic Press, 1953, val. 1, 88p.

RIBEIRO, M.F.B.; BELEM, P.A.D.; PARARROYO, J.H.; de FARIA, J.E. Hipogamaglobulinemia en bezerros. Ara-Bras. Med. Vet. Zoot., Belo Horizonte, $35: 537-46,1983$.

ROBERTSON, S.M. \& CEBRA, J.J. A model for local immunity. La Ricerca in Clinica e Laboratorio, Baltimore, $\underline{\text { bl }}(3)$ : $105-19,1976$. 
ROBISON, J.D.; STOTT, G.H.; DeNISE, S.K. Effects of passive immunity on growth and survival in the dairy neifer. I. Dairy Sci., Champaign, $71(5)=1283-7,1988$.

ROWE, B. \& GROSS, R.J. Escherichia coli diarrhoea. Oxoid Culture, London, $4(1)=21-6,1983$.

RUMESSEN, J.J. Gudmand-Hoyer E. Functional bowel disease: malabsorption and abdominal distress after ingestion of fructose-sorbitol. Gastroenterology, Baltimore, 95: $694-700,1988$.

SAIF, L.J. \& SMITH, L. Enteric viral infections of calves and immunity. J. Dairy Sci., Champaign, 68: 206-28, 1985 .

SAIF, L.J.; REDMAN, D.R.; SMITH, K.L.; THEIL; K.W. Passive immunity to bovine rotavirus in newborn calves fed colostrum supplements from immunized or nonimmunized cows. Infection and Immunity, Washington, D.C., $41(3)$ : $1118-31,1983$.

SASAKI, M.; DAVIS, C.L.; LARSON, B.L. Production and turnover of $\mathrm{Ig}_{1}$ and $\mathrm{Ig}_{2} \mathrm{G}_{2}$ immungglobulins in the bovine around parturation. J. Dairy Sci., Champaign, $\underline{59}$ $2046-55,1976$.

SAUNDERS, D.R. \& WIGGINS, H.5. Conservation of mannitol, lactulose and raffinose by the human colon. Am. J. Physiol., Bethesda, 241: $9397-9402,1981$.

SCHIMIDT, G.W. Biology of Lactation. São Francisco, G.W. Salisbury, 1971. 317p. 
SELMAN, I.E.; DE LA FUENTE, G.H.; FISHER, E.W.; McEWAN, A.D. The serum immune globulin concentration of newborn dairy heifer calves. A form survey. Vet. Rec., London, $\underline{B}: 460-4,1971$.

SHELDRAKE, R.F. \& HSBAND, A.T. Immune defences at mucosal surfaces in ruminants. J. Dairy Sci., Champaign, $\underline{52}$ $599-613,1985$.

SMITH, K.L.; MUIR, L.A.; FERGUSON, L.C.; CONRAD, H.R. Selective transport of $I g G_{1}$ into mammary gland: Role of estrogen and progesterone. J. Dairy Sci., Champaign, 54: $1886-94,1971$.

SMITH, T. LITTLE, R.B. The significance of colostrum to the newborn calf. I. Exp.Med., New York, $36:$ 191-98, 1922.

SNODGRASS, D.R. \& WELLS, P.W. Rotavirus infection in 1 ambs: studies on passive protection. Archives of Virology, Wien Springer, 52: 201-5, 1976.

SNODGRASS, D.R. \& WELLS, P.W. The influence of colostrum of neonatal rotaviral infections. Ann. Rech. Vét., Paris, $\underline{q}(2)=335-6,1978$.

SNODGRASS, D.R.; FAHEY, K.J.; WELLS, P.W.; CAMPBELL; $I$.; WHITELAW, A. Passive immunity in calf rotavirus infection: maternal vaccination increases and prolongs immunoglobulin $G_{1}$ antibody secretion in milk. Infection and Immunity, Washington, D.C., 28 $(2): 344-9,1980$. 
STOTT, G.H.; FLEENOR, W.A.; KLEESE, W.C. Colostral immunoglobulin concentrations in two fractions of first milking post-partum and five additional milkings. I. Dairy Sci." Champaign, 64: 459-65, 1981 .

STOTT, G.H.; MARX, D.B.; MENEFEE, B.E.; NIGHTHENGALE, G.T. Colostral immunoglobulin transfer in calves. II. The rate of absorption. ‥ Dairy Sci., Champaign, 62: $1766-73,1979$.

TENNANT, B.; HARROLD, D.; GUERRA, M.R.; LABEN, R.C. NeOnatal alterations in serum gammaglobulin levels of Jersey and Holstein-Friesian calves. Am. J. Vet. Res.; Chicago, 30: 345-54, 1969.

THOMAS, K.W. \& PEMBERTON, D.H. A freezethaw method for concentrating plasma and serum for treatment of hypogammaglobulinaemia. Ajibak, London, $58(2): 133-42,1980$.

THORNS, C.J.; BELL, M.M.; CHASEY, D.; CHESHAM, J.; RDEDER, P.L. Development of monoclonal antibody ELISA for simultaneous detection of bovine coronavirus, rotavirus serogroup $A$, and Escherichia coli $K 99$ antigen in feces of calves. An. J. Vet. Res., Chicago, 53(1): $36-43$, 1992.

TIZARD, I. Imunologia Veterinária. Trad. da $2 a ̂$ ed. americana, Livraria Roca Ltda., Săo Paulo, 1985. 329p.

TSUNEMITSU, H.; SHIMIZU, M.; HIRAI, T.; YONEMICHI, H.; KUDO, T.; MORI, K.; ONOE, $S$. Protection against bovine rotavirus in newborn calves by continuous feeding of immune colostrum. Jpr. J. Vet. Sci., Tokyo, 51(2): $300-8,1989$. 
TIIPORI, S. The aetiology and diagnosis of calf diarrhoea. Veterinary Record, London, 108: $510-4,1981$.

Van HORN, H.H.; OLAYIWOLE, M.B.; WILCOX, C.J.; HARRIS Jr., B.; WING, J.M. Effects of housing, milk feeding management, and ration formulation of calf growth and feed intake. I. Dairy Sci., Champaign, 59:924, 1976.

VENTORP, M. \& MICHANEK, P. The importance of udder and teat conformation for teat seeking by the newborn calf. I. Dairy Sci., Champaign, 75: 262-8, 1992.

WATSON, D.L. Immunological functions of the mammary gland and its secretion - comparative review. Aust. J. Biol. Sci., East Melbourne, $33: 403-22,1980$.

WELLS, P.W. \& SNODGRASS, D.R. The effects of vaccination on titers of antibody to rotavirus in colostrum and milk. Ann. Rech. Vét., Paris, $\underline{\text { get }}(2)=265-7,1978$.

WODDE, G.N. \& BRIDGER, J.C. Viral enteritis of calves. Veterinary Record, London, 96: 85-8, 1975.

WOODE, G.N.; JONES, J.; BRIDGER, J. Levels of colostral antibodies against neonatal calf diarrhoea virus. Veterinary record, London, $97: 148-9,1975$. 
APEND ICE 


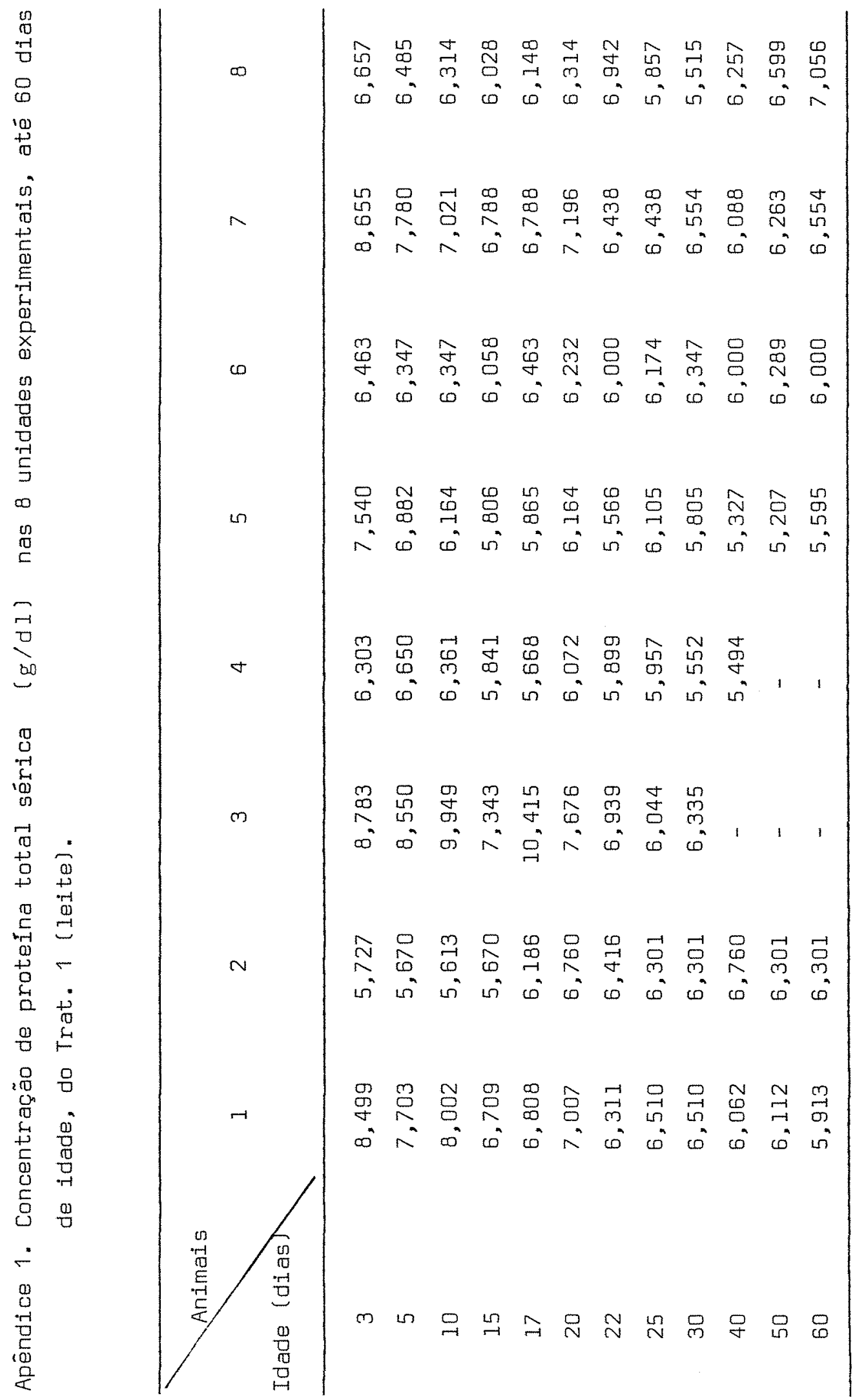




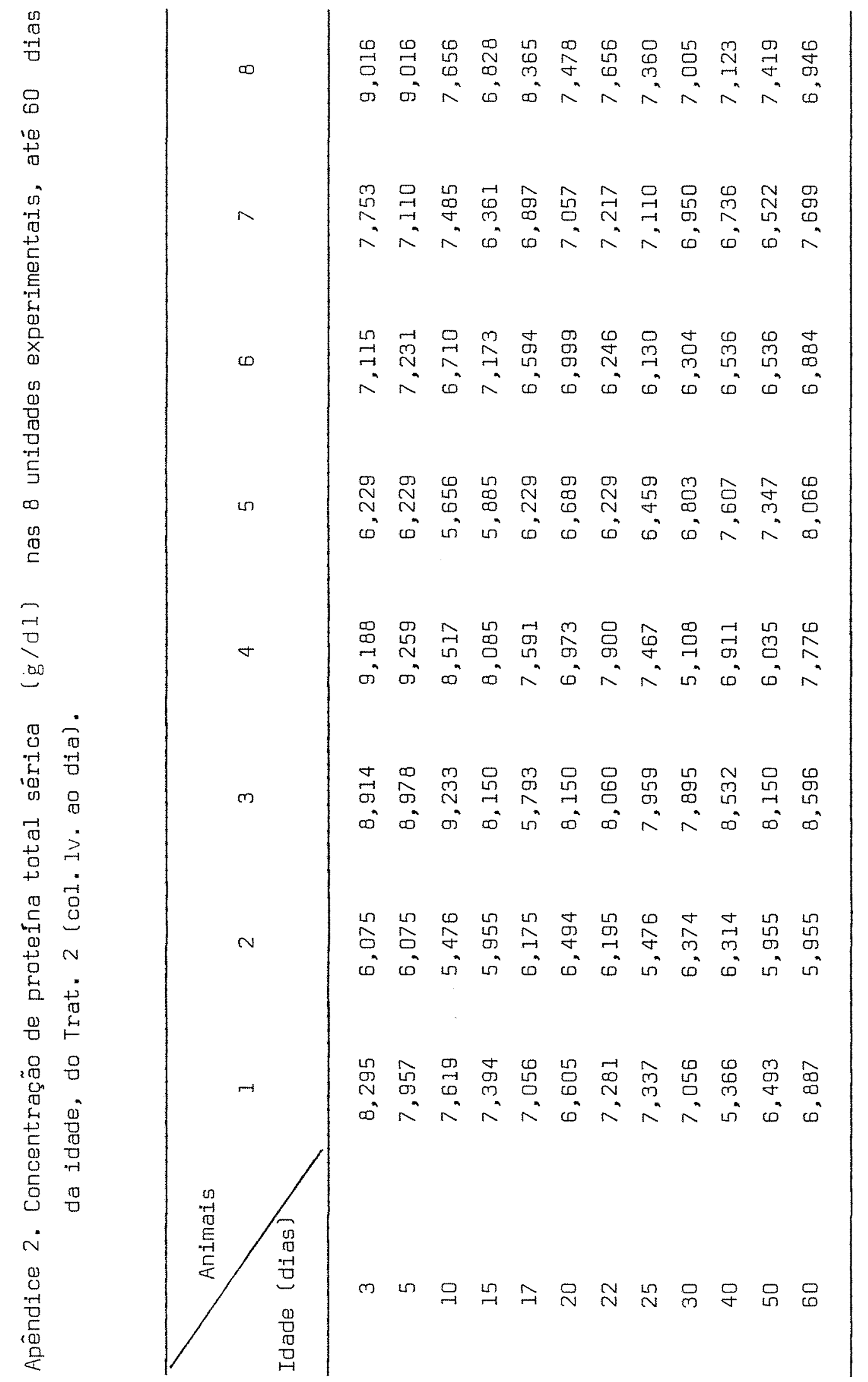




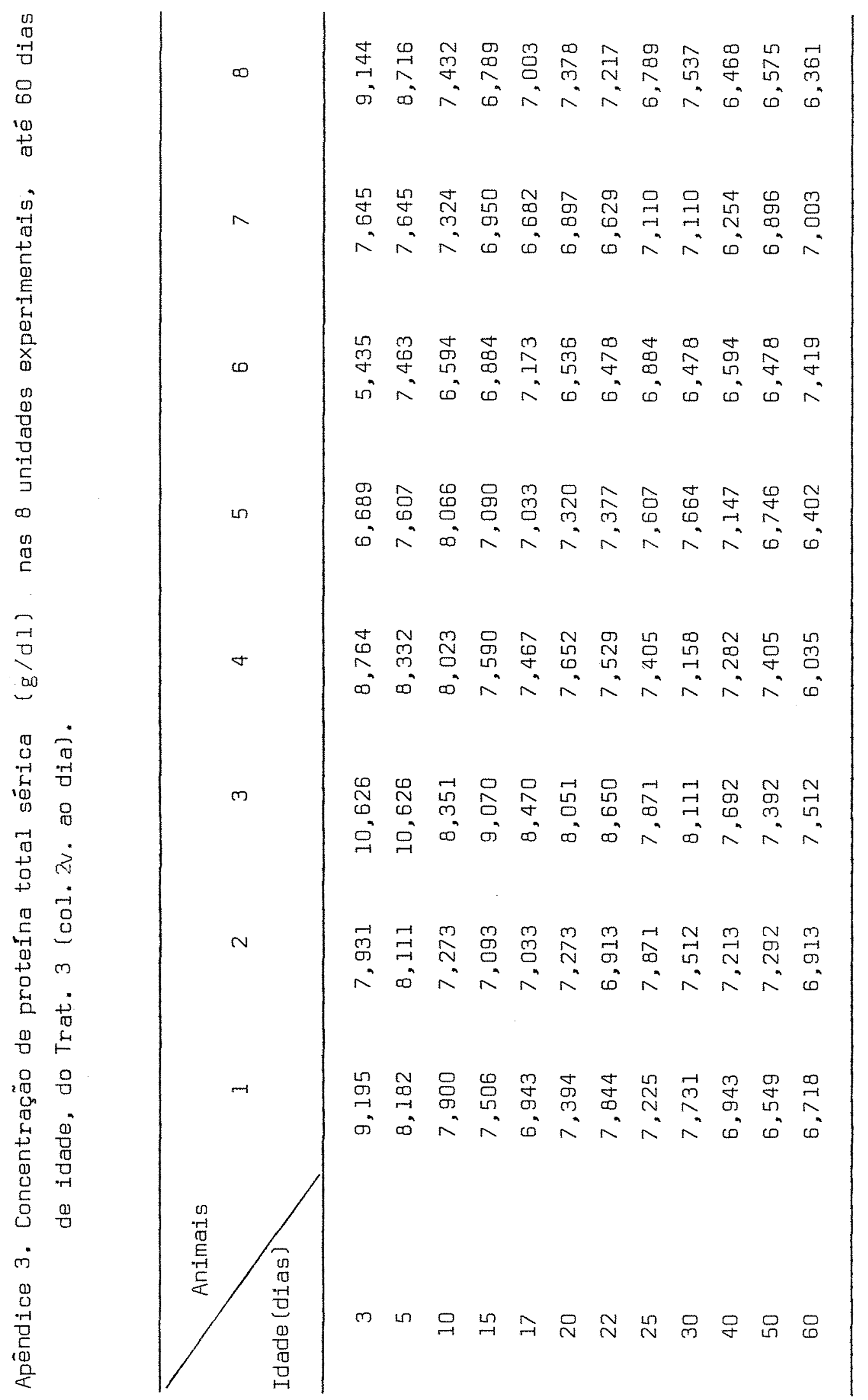




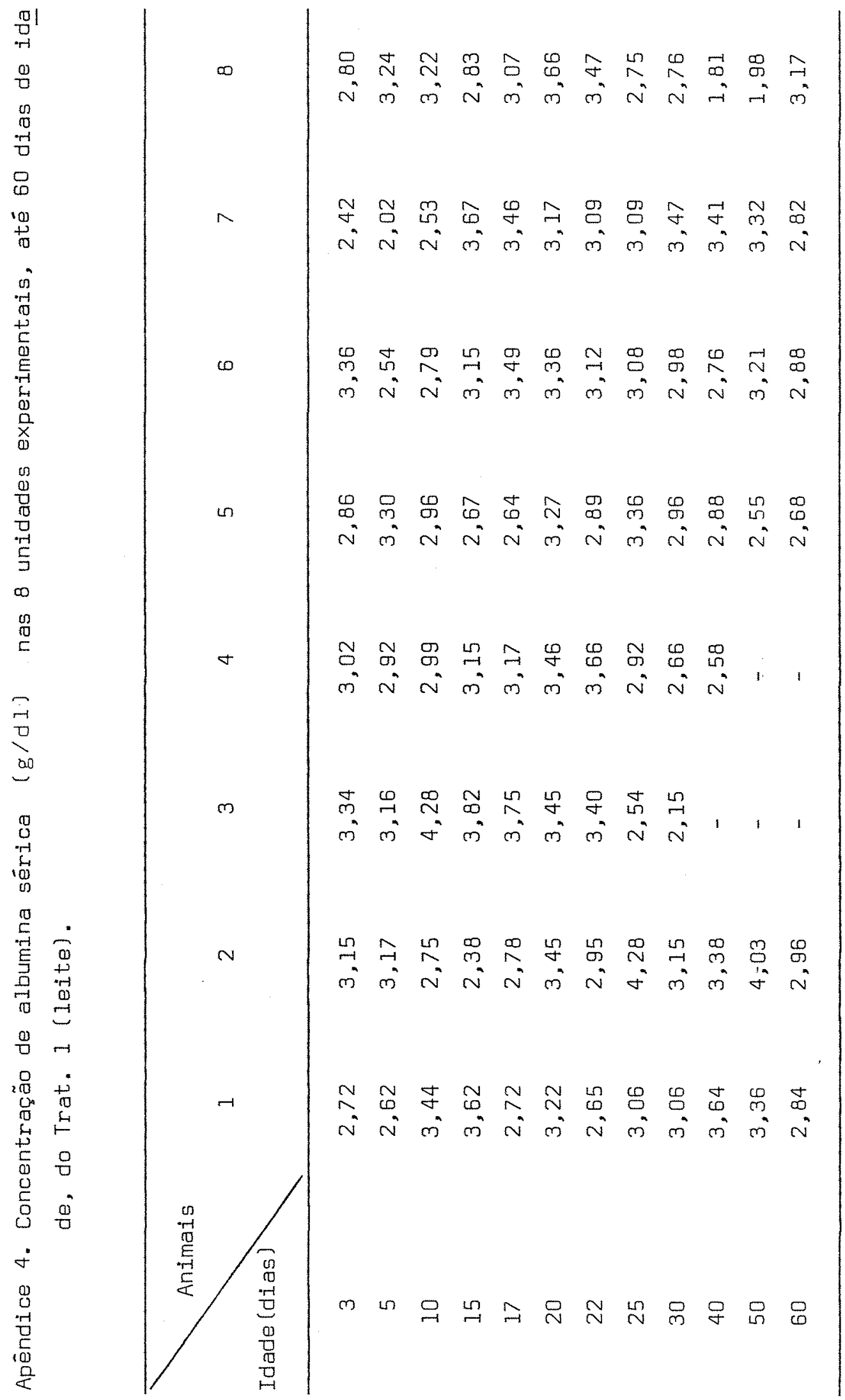




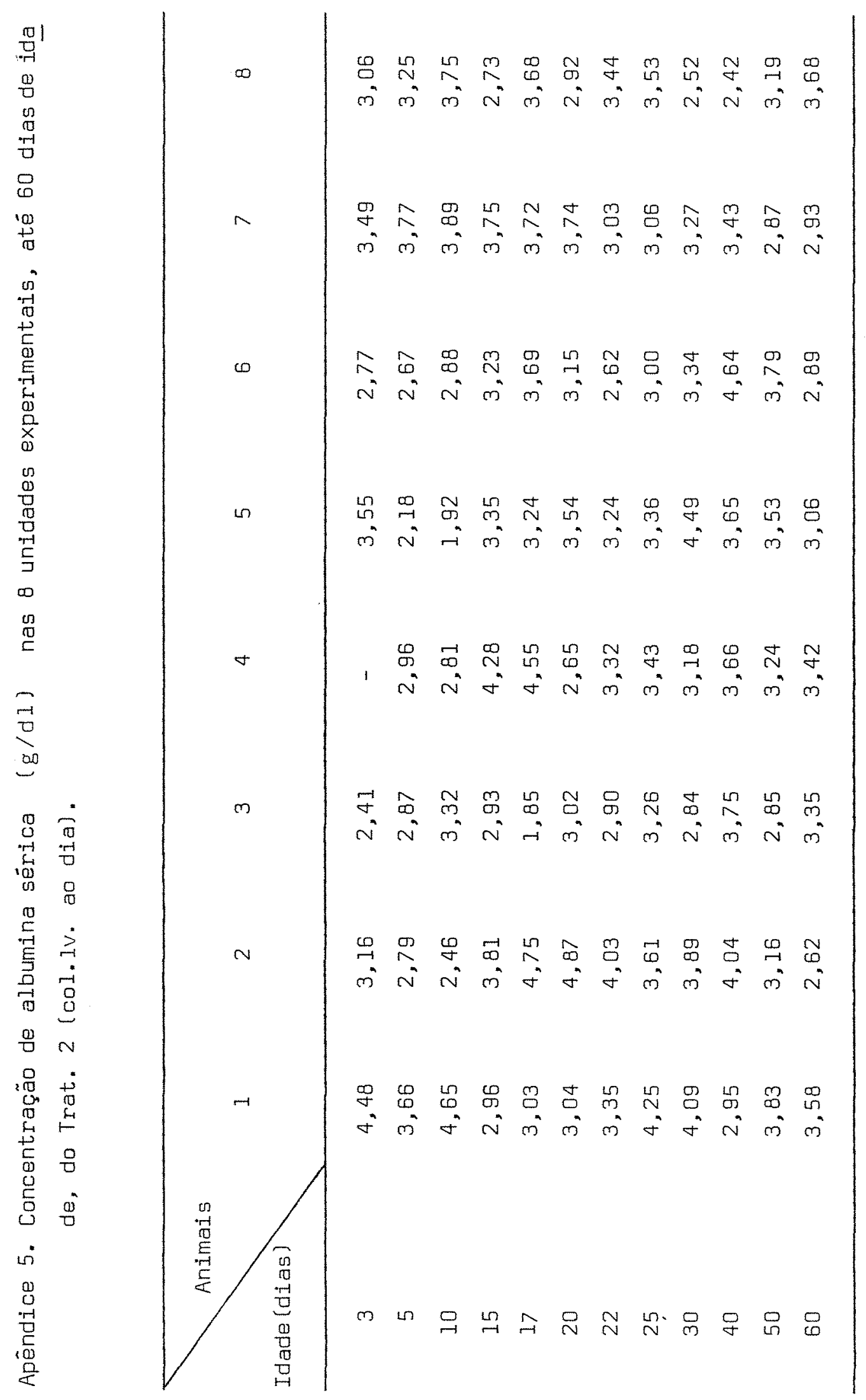




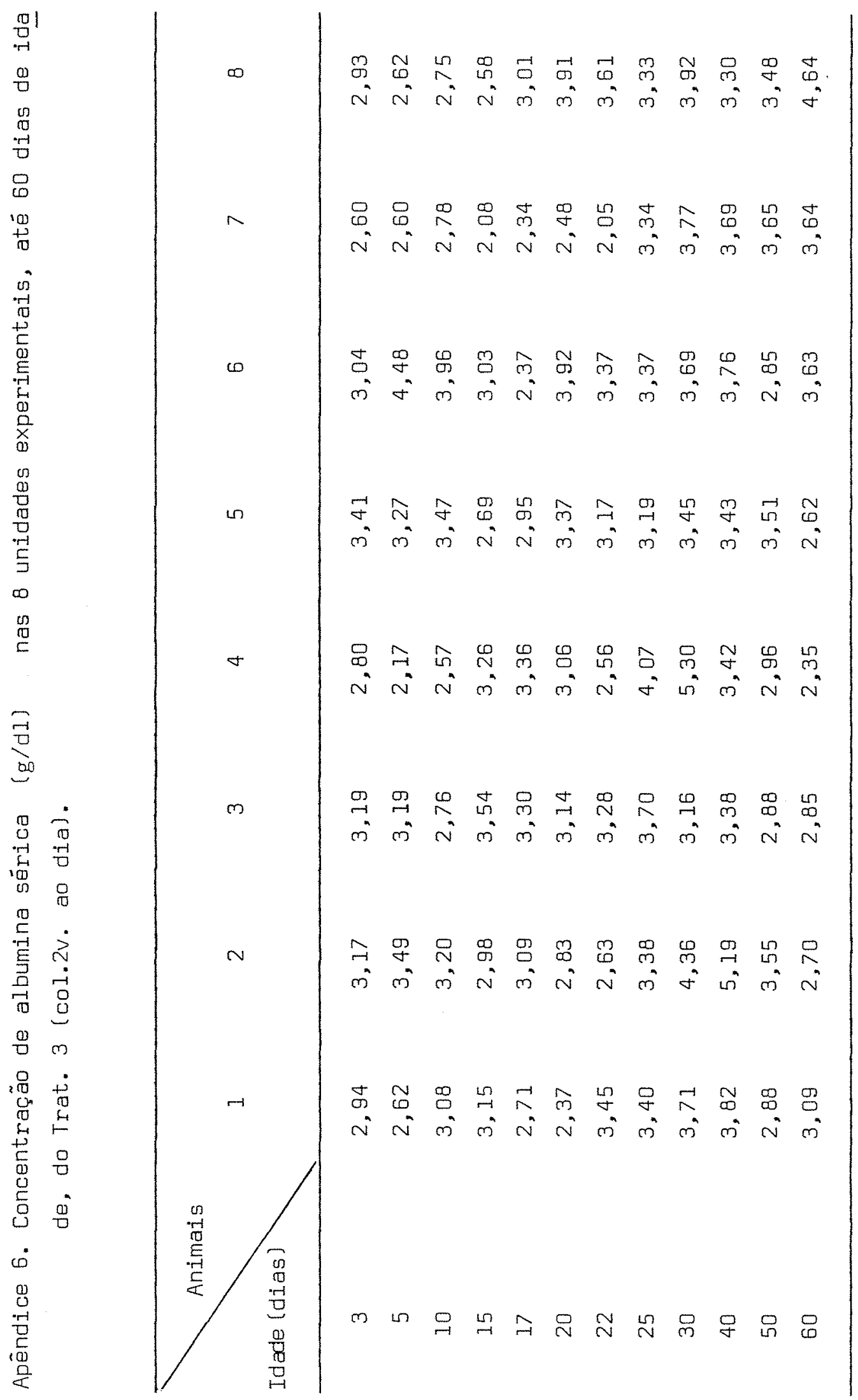




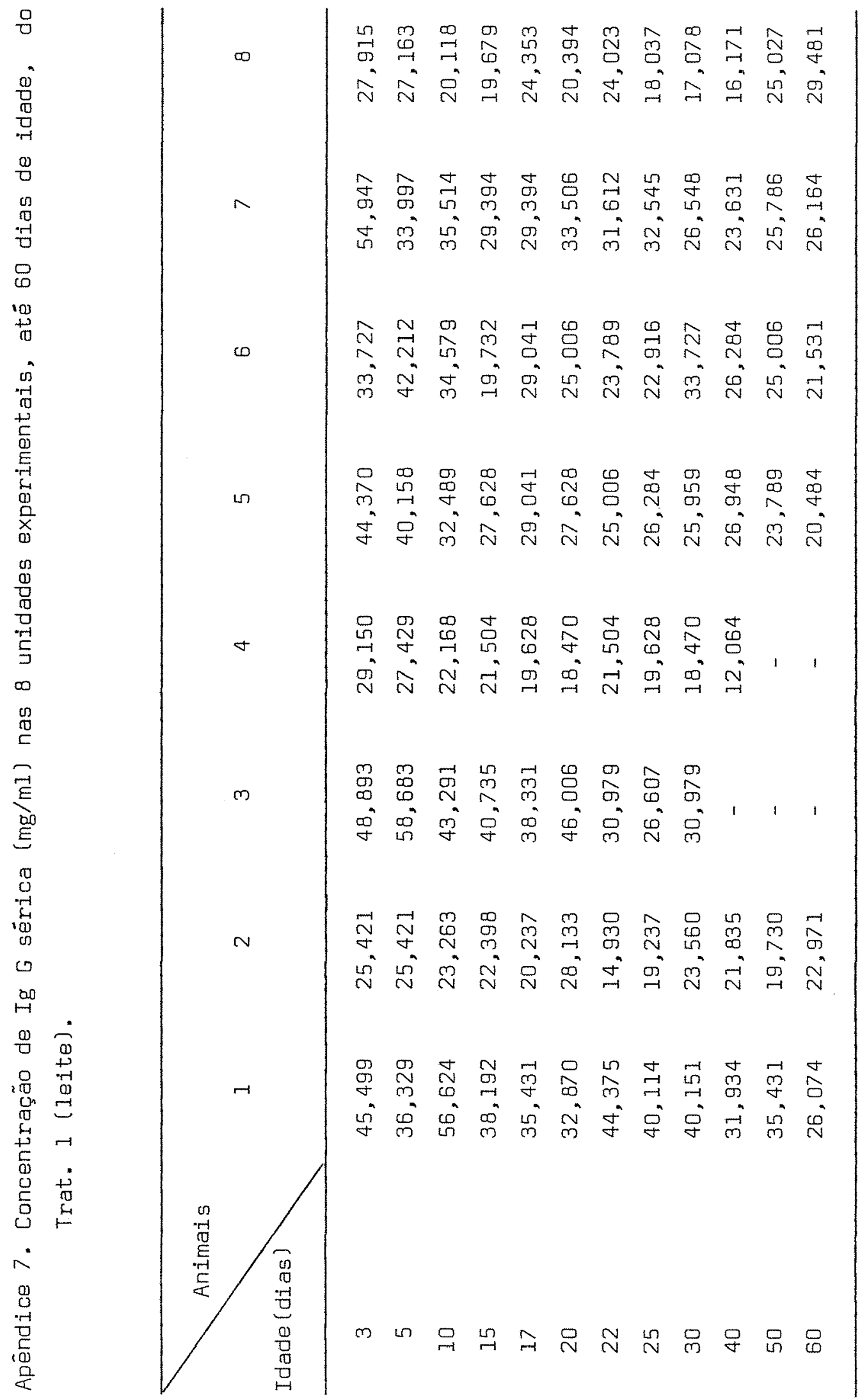




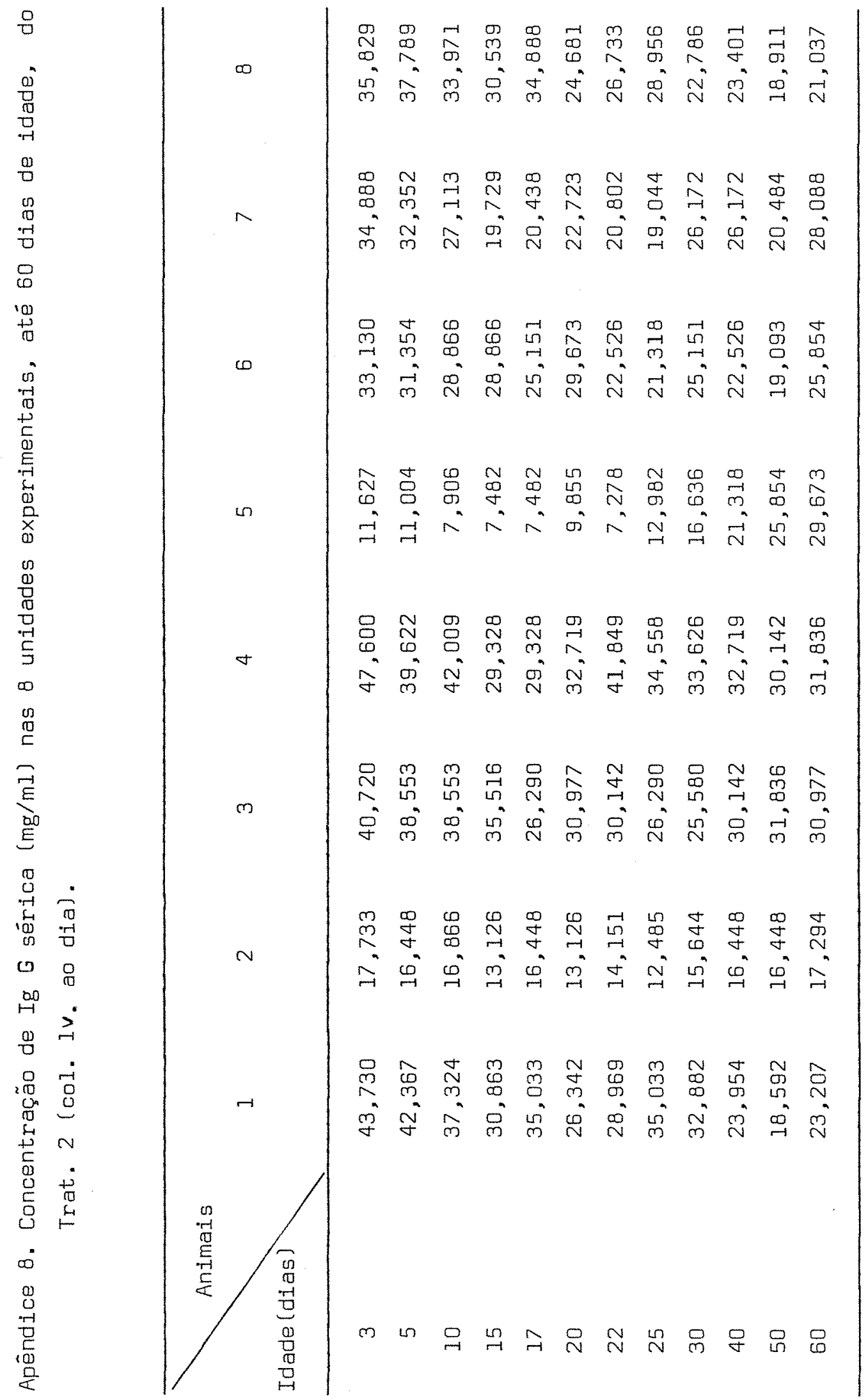




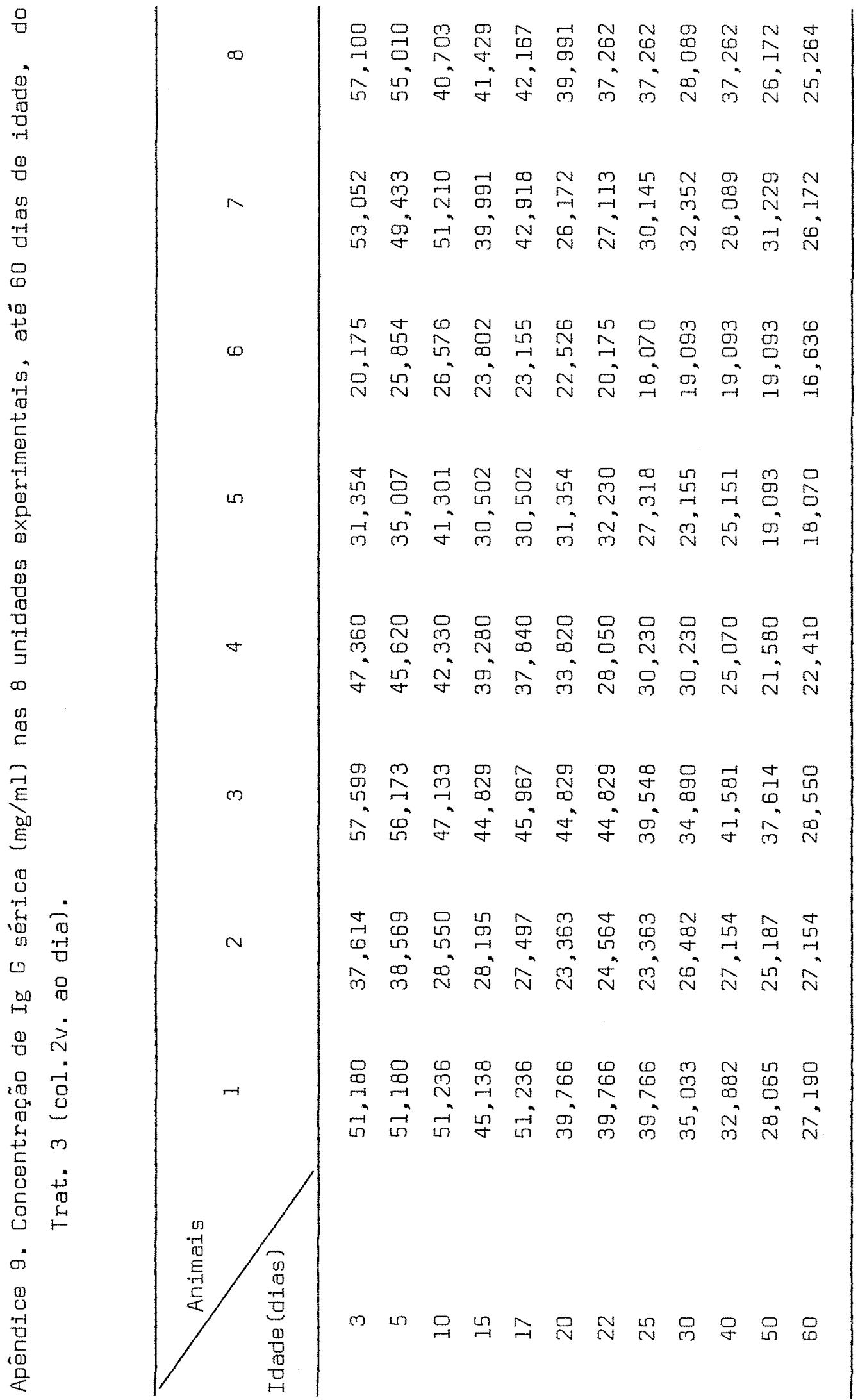


Apêndice 10. Composição e niveis de nutrientes do concentrado fornecido para bezerros na Fazenda Agrindus.

- Umidade $(\%) \quad 11,83$

- Proteina Bruta $(\%) \quad 17,97$

- Matéria Mineral $(\%) \quad 6,33$

- Cálcio $(\%) \quad 1,34$

- Fósfora 0,62

- Estes valores foram fornecidos pela Fazenda Agrindus. Os ingredientes básicas da ração, batida na própria fazenda são: fubá $(52 \%)$; farelo de soja $(25 \%)$; farelo de trigo $(15 \%)$; suplemento mineral $(3 \%)$; leite em pó (3\%); calcita branca $(1 \%)$ e Premix vitamínico bovino $(0,2 \%)$. 